\title{
From Prohibition to Decriminalization: Interrogating the Emerging International Paradigm Shift in the War on Drugs Discourse
}

\author{
by
}

Sophie O’Manique

A thesis submitted to the Faculty of Graduate and Postdoctoral Affairs in partial fulfillment of the requirements for the degree of

Master of Arts

in

Political Economy

Carleton University

Ottawa, Ontario

(C) 2014, Sophie O'Manique 


\begin{abstract}
This project aims to interrogate the emerging counter-hegemonic war on drug discourse through a neo-Gramscian lens. Given that the estimated \$2.5 trillion-dollar effort (Wood, 2011) has done little to stifle either drug consumption or production over the course of the past 40 years, a consensus is beginning to emerge surrounding the need for a policy change, especially in the countries of Latin America. While drug use was once something to be dealt with solely by the juridical and military branches of government, governments in the Americas increasingly understand drug use as a public health issue, including, although to a lesser extent, the United States. This thesis will focus specifically on the Bolivian and Guatemalan cases to ask if we are seeing the creation of a new hegemony in the War on Drugs context.
\end{abstract}




\section{Acknowledgements}

First, and foremost, I would like to thank my supervisor Laura Macdonald for her patient support through this project, as well as Cristina Rojas for her thoughtful feedback and Justin Paulson for acting as the external on my committee. I owe many thanks to Donna Coghill, who is not only one of the most helpful administrators I have been lucky enough to encounter but also is a very kind friend. My parents, Colleen O'Manique and Christy Gombay, have been very helpful to me, especially in assuring me that I could, in fact, do this. I would also like to thank Mark Seasons, Patricia O'Manique and Brydon Gombay for many pep talks along the way. To the other students in my department, I am so happy to have met such an intelligent, engaged and lovely bunch of people. And finally, I am lucky to have many dear friends who I would like to thank for showing me so much love, encouragement and support through this sometimes challenging process. 


\section{Table of Contents}

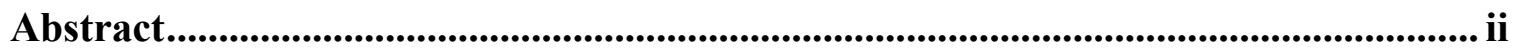

Acknowledgements .........................................................................................................iii

Table of Contents .................................................................................................... iv-v

1 Chapter: Introduction ................................................................................................. 1

$1.1 \quad$ Theoretical framework ………………………………………………………. 4

$1.2 \quad$ Methodological considerations............................................................................ 26

$1.3 \quad$ Outline of this thesis ....................................................................................... 28

2 Chapter: Understanding the orthodox, War on Drugs discourse ......................... 30

2.1 The construction of drug use as deviant ............................................................. 31

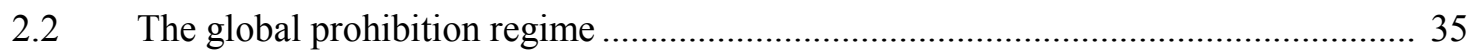

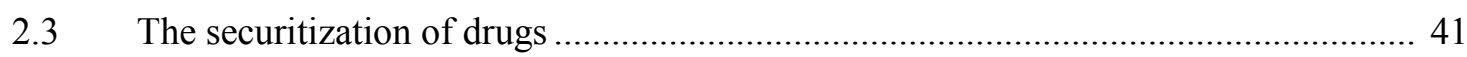

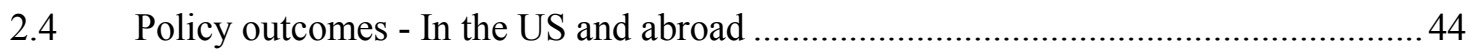

2.5 Waging the drug war in the neoliberal context.................................................. 50

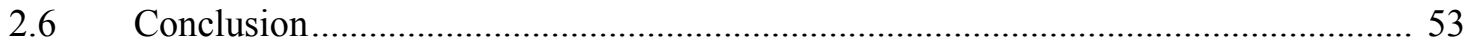

3 Chapter: The shifting trajectory of the international discourse on drugs ......... 55

3.1 The global prohinbition regime discredited ….......................................................... 56

3.2 The emergence of a new discourse at the international level .................................. 61

3.3 The emergence of a new discourse in Central and South America ........................... 74

3.4 The position of the US and the UN: Maintaing the global prohibition regime .......... 78

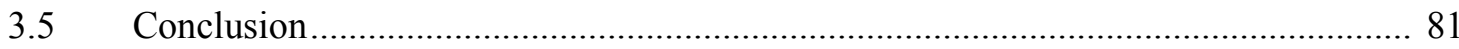

4 Chapter: Case study - Bolivia ..................................................................................... 84

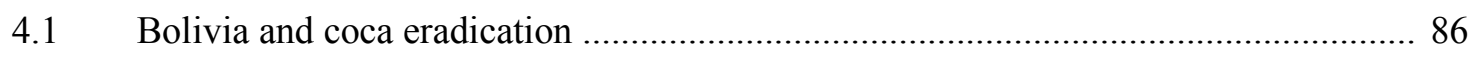

4.2 The Morales government and the emergence of a counter hegemonic drug policy .... 94 


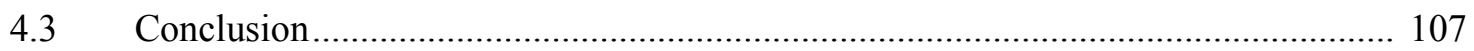

5 Chapter: Cases study - Guatemala............................................................... 108

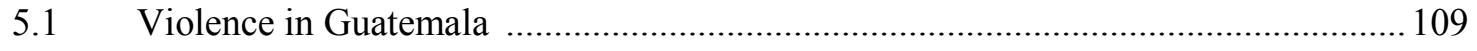

5.2 The election of Otto Pérez Molina ….................................................................. 114

5.3 Pérez Molina's approach to managing the drug problem ..................................... 116

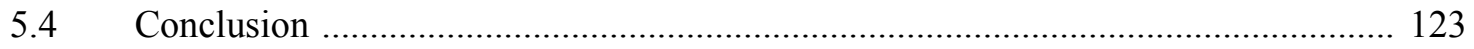

6 Chapter: Conclusion ............................................................................................ 125

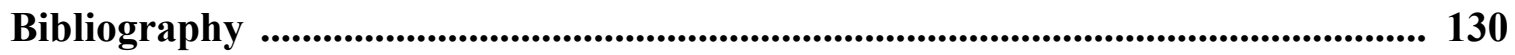




\section{Chapter: Introduction}

The War on Drugs effort began under the Nixon administration in the mid 1960s in response to the rising use of illicit drugs in the United States. Premised on supply reduction strategies for reducing US domestic consumption, the US strategy for managing the drug problem has left few corners of the globe untouched in its effort to stifle narcotic drug use. Given that the majority of drug production and trafficking for US consumption occurs in South and Central America, no other region in the world has felt the fallout of the War on Drugs quite like Latin America. Backed by international law in the form of the 1961 Single Convention on Narcotic Drugs, US efforts to combat production and trafficking have favoured military based, supply side strategies, which have worked primarily to exacerbate the violence and devastation associated with the market for illicit drugs. In constructing illicit drugs as a security threat, consecutive American administrations have justified the implementation of such measures. Emily Crick writes that the discourse employed by advocates of the War on Drugs has "created the space for policies that themselves threaten human rights and human security in the name of fighting this 'evil'” (2012: 408). Others present the argument that the War on Drugs effort in the Latin American region was primarily about maintaining US hegemony in the hemisphere. In the introduction to his book Empire's Workshop, in reference to US-Latin American relations, Greg Grandin writes,

... The region has long served as a workshop of empire, the place where the United States elaborated tactics of extraterritorial administration and acquired its conception of itself as an empire like no other before it... Unlike European empires, ours was supposed to entail a concert of equal, sovereign democratic American republics with shared interests and values, led but not dominated by the United States - a conception of empire that remains Washington's guiding vision. $(2007: 2)$ 
We can understand the War on Drugs effort in Latin America as occurring in a period of unbridled American hegemony (Robinson, 2005: 2), and the tactics employed as reflective of the US's position as the regional hegemon. Whatever the intentions of consecutive American administrations in the formulation of regional drug policies and the implementation of supply reduction strategies, for millions of Latin Americans, the implications have been disastrous.

Despite the destructive history of the War on Drugs, it can be argued there have been significant shifts in international arenas in recent years concerning how the issue of illicit drug use and trafficking should be managed at the transnational, national and more local levels. Given that the estimated \$2.5 trillion-dollar effort (Wood, 2011) has done little to stifle either drug consumption or production over the course of the past 40 years, a consensus is beginning to emerge surrounding the need for a policy change, especially in the countries of Latin America. This shifting discourse has emerged across scales and ideologies - although US President Obama still opposes the idea of legalization for most currently banned substances. While drug use was once something to be dealt with solely by the juridical and military branches of government, governments in the Americas increasingly understand drug use as a public health issue, including, although to a lesser extent, the United States. Further, there is an increasing recognition of the socioeconomic factors that lead individuals to turn to drug production and trafficking. Given this recognition of the drug problem as being multifaceted and context specific, we are beginning to see innovation in drug policy making that recognizes both the failures of the old approach to drug control and the need for dynamic, context specific, and less militaristic approaches to stemming drug production and consumption. Many have even 
argued for an end to the prohibition of some banned substances, and some jurisdictions have moved in this direction.

Although this new emerging discourse finds support from prominent individuals in international governance, international organizations, and some Western governments, the most significant changes in terms of substantive shifts in policy and discourse, are happening in the Latin American region. This thesis will focus specifically on the Bolivian and Guatemalan cases to ask if we are seeing the creation of a new hegemony in the War on Drugs context. Why have these two countries, whose governments are situated in very different locations on the ideological spectrum, with different histories and facing very different challenges pertaining to drug control, espoused similar strategies that are in contention with the dominant approach as espoused by the US? The fact that the most substantive shifts are occurring in the Latin American region can in part be attributed to the fact that, beginning in the 1980s, the region has been the front line of the War on Drugs. Further, the push towards repressive drug policy occurred in conjunction with the push towards neoliberal reform, exacerbating the negative effects of drug policy while simultaneously pushing more individuals into the informal sector given a lack of alternatives. The very simple fact that the imposition of such strategies by consecutive US administrations has exacerbated the violence associated with the drug trade and has plunged millions of Latin Americans deeper in to poverty can explain the shift away from such repressive policies. However, the fact that these policies have not delivered upon their promises is not the sole reason for which we are seeing this shift. We can understand the decline of the US approach to drug policy as being contingent upon the move away from neo-conservative governance in the United States, both in terms of 
shifting attitudes towards recreational drug use and shifting attitudes towards direct intervention into other countries in the wake of perceived failed efforts in Iraq and Afghanistan. Further, the decline of the United States as the regional hegemon in the Americas has allowed for the emergence of a counter-hegemonic regional bloc and the opening of spaces for policy innovation and alternatives. We have to understand this shift towards an end to prohibition and the adoption of a more communitarian approach to managing the drug problem as occurring in a context that allows it - such shifts would have likely been inconceivable even a decade prior. Finally, it is important to recognize that successes associated with policy innovations in countries like Bolivia and Uruguay are lending legitimacy to new approaches to managing the drug problem. Given that the issue in question is contemporary in nature and evolving with each passing day, this project aims to establish a framework to understand the changes that are likely to come in the near future as well as to contribute to the literature on an issue that at this time remains relatively unexplored.

\subsection{Theoretical framework}

This project will draw heavily on the works of neo-Gramscian theorists Robert W. Cox and William Robinson, as well as, to a lesser extent, liberal theorists focussed on international norm diffusion, in order to construct a framework of analysis for understanding the emerging process of change in drug policy at the level of the state and to argue that we are seeing the emergence a strong counter-hegemonic discourse in the arena of drug policy. Liberal notions of international norm diffusion, theorized by constructivist IR thinkers, discuss the process by which an idea eventually becomes an 
internationally accepted norm. Absent from the discussion of the liberal perspective, however, is the role that power dynamics play in terms of which ideas become widely accepted norms and which do not. Neo-Gramscian scholars would critique the liberal school of thought on these grounds. For scholars like Robert W. Cox and William I. Robinson, relationships of power are central to a discussion of ideational hegemony. Which ideas come to be internationally held norms and which do not is fundamentally dependent on the dynamics of power at play. Neo-Gramscian theorists understand ideological change as being linked to changes in the relations of production and changes in global power relations. While the liberal literature is helpful in outlining the mechanical process by which domestic norms become internationalized, this project will rely heavily upon the neo-Gramscian literature, as it is difficult to have any understanding of the US anti-drug project in Latin America, and the new emerging consensus, without a grasp of the dynamics of power and ideational hegemony at play.

\section{i) Liberal international norm diffusion theory}

Susan Park is helpful in surveying the theoretical literature on international norm diffusion. Park posits that International Organizations (IOs) can be understood as "carriers" and "diffusers" of international norms. Therefore, for Park, IOs can act as agents that shape and shift international norms. According to Park, "norms are diffused through the international system and taught to states via IOs" (2006: 343). This explains how states with seemingly divergent interests can come to similar policy positions (Park, 2006: 343). Park cites the historical trajectory of a given institution and the actors that populate that institution as the primary agents in the formation of the norms to be 
disseminated (2006: 353). Absent from Park's discussion however, is how dynamics of power play out in a given institution to shape international norms.

Martha Finnemore is a constructivist IR scholar and is considered one of the most prominent academics looking at international norm diffusion. Finnemore and Kathryn Sikkink's article "International Norm Dynamics and Political Change," is useful in explaining what norms are, where they originate and how they evolve over time. The authors define a norm as "a standard of appropriate behavior for actors with a given identity" (1998: 891). Norms are "shared assessments," in that in order to be considered a norm they have to be embraced by a multiplicity of actors (Finnemore and Sikkink, 1998: 891). Norms work to constrain actors - they create a framework for what behaviours are acceptable and which are not (Finnemore and Sikkink, 1998: 892).

For Finnemore and Sikknik, there is a deep connection between the domestic and international levels, in that international norms usually originate from domestic norms (1998: 893). This is quite clear in the formation of international drug policy in relation to American drug policy. The authors understand norm change as being characterized by "different actors, motives, and mechanisms of influence" (Finnemore and Sikknik, 1998: 895). The authors write, "in an ideational international structure, idea shifts and norm shifts are the main vehicles for system transformation" (1998: 894). Finnemore and Sikkink understand "norm influence" as being a three-stage process where first we see the emergence of the norm, second the wide acceptance of the norm and third the internalization of the norm in question at which point the norm in question is no longer the subject of broad public debate (1998: 895). Norm internalization is exemplified by international consensuses surrounding issues like slavery and human trafficking. For 
Finnemore and Sikkink, the emergence and diffusion of norms is contingent upon the existence of "norm entrepreneurs" and organizational platforms to which norm entrepreneurs can take their qualms (1998: 899). Organizational platforms can be those created specifically for the propagation of the norm, like for example, the World Wild Life Fund or Green Peace, or existing international institutions, like the UN. The authors also posit that a certain threshold or "tipping point" needs to be reached in order for a given norm to reach the second stage (1998: 902). This threshold is not reached simply by a critical mass of countries accepting the norm in question. Rather, dynamics of power at the international level often require that specific states accept the norm in question for it to reach the third stage of norm diffusion. Once an emerging norm reaches this "tipping point," the authors argue that we see a process of contagion, or "international socialization" (1998: 902). When this occurs, international pressures to conform hold more weight than domestic political concerns (1998: 902). The authors stress the importance of legitimacy for states, not only at the international level but also for the citizenry of a given state, as a powerful driver of norm acceptance (1998: 902).

Finally, Ethan Nadelmann's article, "Global prohibition regimes: the evolution of norms in international society," discusses the moral dimensions of international norm diffusion by examining how specific norms, like slavery, human trafficking, piracy and drug prohibition have evolved into "global prohibition regimes" (1990: 480). Nadelmann cites emotional factors, unrelated to economic motivations, as powerful drivers of norm creation and diffusion (1990: 480). Nadelmann argues that "religious beliefs, humanitarian sentiments, faith in universalism, compassion, conscience, paternalism, fear, prejudice and the compulsion to proselytize" are central to the creation of global 
prohibition regimes (1990: 480). Nadelmann writes, " the compulsion to convert others to one's beliefs and to remake the world in one's own image has long played an important role in international politics" (1990: 471). Nadelmann understands "transnational moral entrepreneurs" as the agents of the international diffusion of norms that are moral in character. Here he draws on Becker's notion of "moral entrepreneurs" as those who "operate with an absolute ethic in seeking to create new rules to do away with a perceived great evil" (Nadelmann, 1990: 482). Similar to the neo-Gramscian theorists, Nadelmann sees international organizations as agents of norm diffusion and highlights the role that "dominant" societies, like the United States, play in the formation of international norms and global prohibition regimes (199: 484). For Nadelmann, the diffusion of international norms and the emergence of global prohibition regimes are fundamentally contingent on globalization and what he calls the development of a "universal international society" (1990: 483). He also stresses that in this process, the primacy of Western Europe, and later the United States cannot be overstated (Nadelmann, 1990: 484).

Nadelmann highlights a five-stage, "evolutionary pattern" in the formation of global prohibition regimes that is paraphrased as follows:

1. Societies understand the activity in question as legitimate, albeit perhaps only under certain conditions of for certain groups in society.

2. The activity becomes re-defined as problematic or illegal.

3. Proponents of the prohibition regime begin to call for the criminalization of the activity in question at the international level.

4. Should stage three be successful, the activity becomes prohibited and "international institutions and convention emerge to play a coordinating role" (1990: 485)

It should be noted that in order for an international prohibition regime to come into existence, the issue at hand has to be one not easily managed within the confines of a 
single nation state. The problem of illicit drug production, trafficking and consumption, for example, is not one that can be easily managed within a single country.

It is not difficult to criticize the liberal literature on international norm diffusion in that it gives little credence to peripheral countries in both the processes of norm formulation and diffusion, and their capacity to resist the adoption of certain norms. While the liberal literature is useful here in providing definitions for key concepts, outlining the mechanical process by which norms come to be held internationally and theorizing the role of "norm" or "moral" entrepreneurs and IO's in the process of norm diffusion, given that the most significant challenges to the global drug prohibition regime are emanating from Latin American, and therefore peripheral governments, the liberal literature is not sufficient for exploring the question at hand. Further, the liberal literature, with the exception of the Nadelmann piece surveyed above, largely ignores how dynamics of power give certain actors the capacity to impose or propagate their ideas (Park, 2006: 342). While Nadelmann's conception of international "moral entrepreneurs" is useful for conceptualizing the actors involved in the propagation of counter-hegemonic drug policy or the construction of a new hegemony and takes into account the dynamics of power at play at the level of IOs, again, his framework of analysis cannot sufficiently capture the dynamics of power at play. Neo-Gramsican conceptions of global ideational hegemony place emphasis on changing dynamics of global power relations as the principle drivers of ideological change and as central to the creation of new global hegemonies. As changing dynamics in the international distribution of power are central to shifts in the drug policy discussion, the liberal literature, although helpful, is by no means sufficient in explaining the question at hand. 


\section{ii) Neo-Gramscian conceptions of hegemony}

The neo-Gramscian scholars understand the world system as one that is fundamentally shaped by dynamics of power. William I. Robinson is helpful in surveying the literature on different theoretical conceptions of hegemony. In defining Gramsci's conception of ideological or consensual hegemony, he writes:

Hegemony in the more generic sense meant by Antonio Gramsci as the way in which a ruling group establishes and maintains its rule. Hegemony is rule by consent, or the cultural and intellectual leadership achieved by a particular class, class fraction, stratum or social group, as part of a larger project of class rule or domination. (2005: 2)

Conversely, in defining what he calls "hegemony as the exercise of leadership within historical blocs within a particular world order," he understands it as, "a view of hegemony that combines the loose sense of some preeminent state power in the world system with the more specific sense of the construction of consent or ideological leadership around a particular historic project" (2005: 2). According to Robinson then, the United States was able to achieve a position of international ideational hegemony in the post-war period due to "the development of a Fordist-Keynesian social structure of accumulation that became internationalized under the leadership of the US capitalist class," (2005: 2) rather than based on economic or military dominance.

In Production, Power and World Order, Cox examines the power relations of production, based on the premise that production is "a fundamental activity that affects a range of other important human relationships and the organization of society as a whole" (1987: IX). Cox chronicles the development of the social relations of production beginning with the emergence of "the modern state" in the fifteenth or sixteenth Century (1987: 110). Of relevance for our purposes, is his discussion of world orders and how 
norms come to be diffused across time and space. Cox posits that world orders can be considered as either hegemonic, or not (1987: 7). He understands the time period beginning with the First World War and culminating in the end of the Second World War as being non-hegemonic (1987: 7). Cox typifies the time period prior to the onset of World War One as "Pax Britannica” (1987: 7). Cox calls the post- World War II war period "Pax Americana" (1987: 7). Cox's conception of hegemony extends beyond traditional international relations conceptions that understand hegemony as the hard, military and economic power of any one given state. For Cox, hegemony is both ideational and consensual. Cox defines hegemony as:

... more than the dominance of a single world power. It means dominance of a particular kind where the dominant state creates an order based ideologically on a broad measure of consent, functioning according to general principles that in fact ensure the continuing supremacy of the leading state or states and leading social classes but at the same time offer some measure of prospect of satisfaction to the less powerful (1987: 7).

And so, for Cox, relations of production in any given country are shaped by international norms, given that production becomes connected through "mechanisms of a world economy" and "linked into world systems of production" (1987: 7). This is facilitated by class-based allegiances between the dominant power and elites in any given country (Cox, 1987: 7). Cox writes, "an incipient world society grows up around the interstate system, and states themselves become internationalized in that their mechanisms and policies become adjusted to the rhythms of the world order" (1987: 7). Meanwhile, in periods characterized as non-hegemonic, Cox writes that these tendencies can be reversed (1987: 7). 
For Cox, while modes of social relations of production are established by the state, the structure of the state is conditioned by structures of world order acting upon the state (1987: 7). Cox understands the state as being the agent that can either act to maintain existing structures of production, and the social relations that stem from them, or facilitate the construction of new relations of production (1987: 7). Under Pax Americana, the consolidation of American hegemony facilitated the exportation and emulation of American methods of production abroad (1987: 266). Additionally, the presence of a hegemonic power in the post-war period set limits on what state structures were to be tolerated (1987: 266). This being said, American hegemony was consolidated to a weaker degree in the peripheries, as opposed to core countries that faced harsher ramifications for stepping outside the boundaries of what was internationally understood as acceptable (1987: 266). Cox argues that the onset of Pax Americana facilitated the creation of a global hegemonic order premised on classical trade theory that is characterized by the connection of national economies through the flow of goods, capital and species (1987: 244). A principle driver of this hegemonic order is the emergence of transnational production organizations, which facilitate the homogenization of consumer habits, social values and productive technologies, on the basis of existing differences (1987: 245). Given that 'development' becomes contingent upon attracting transnational production organizations, or foreign capital, to a given country, policy has to be formulated on the basis of what is acceptable to foreign capital, so as to attract it, thus facilitating the homogenization of state structures world wide.

Cox creates a series of categories to describe the different types of states that populate the world system. Of concern for our purposes is that of the 'protostate.' Within 
the category of protostates there is variation. Generally, Cox understands the protostate as that which the world economy does not depend on "to any significant extent" (1987: 218). The primary economic activity of the protostate is agriculture (1987: 218). While, as previously stated, the continued viability of the world economy is not necessarily contingent upon the economic wellbeing of any given protostate, their political and economic stability is of concern to the "world-economy managers" in that the deterioration of said stability has the potential for spillover and could pose a threat to the continued viability of the world system in which they are situated (1987: 218). Cox posits that international lending institutions like the World Bank and the International Monetary Fund, alongside the United Nations, work to maintain a degree of economic and political stability in protostates (1987: 218-219). Protostates, therefore, become more susceptible to the potential for agents of American ideational hegemony (i.e. international lending and governance institutions) meddling in their internal affairs and propagating international norms (Cox, 1987: 218-219).

Also of interest is Cox's account of the process of the "internationalizing of the state." Cox writes,

The meaning given to the term internationalizing of the state can be expressed in three points: First, there is a process of interstate consensus formation regarding the needs or requirements of the world economy that takes place within a common ideological framework... Second, participation in this consensus formation is hierarchically structured. Third, the internal structures of the state are adjusted so that each can best transform the global consensus into national policy and practice (1987: 254).

In order to have access to international institutions, and to accrue the benefits of having access to these institutions, states have to satisfy their conditions. Cox understands international institutions as the "primary agency of conformity to world-hegemonic 
order" (1987: 267). Access to these agencies is especially important for peripheral states, which are more vulnerable to external shocks in the global market place. Cox writes that the institutions of the world economy, like the World Bank, IMF and UN, “...incorporated mechanisms to supervise the application of the system's norms and to make financial assistance and other benefits of the system conditional upon reasonable evidence of intent to live up to these norms" (1987: 267). This is very much evident in the War on Drugs context given the haste with which certain American administrations have issued sanctions, whether they be financial or diplomatic, based on non-compliance with the norms of international drug policy.

In his earlier article, "Gramsci, Hegemony and International Relations: An Essay in Method," Cox applies Gramsci's notion of ideological/consensual hegemony to the wider international political economy. Cox understands international institutions as being a facilitator of American ideational hegemony in the post World War Two context. Cox writes, “....international organization functions as the process through which the institutions of hegemony and its ideology are developed" (1983: 172). Cox's argument surrounding international institutions as agents of ideational hegemony is premised on 5 points:

(1) they embody the rules which facilitate the expansion of hegemonic world order; (2) they are themselves the product of hegemonic world order; (3) they ideologically legitimate the norms of world order; (4) they co-opt the elites from peripheral countries and (5) they absorb counter hegemonic ideas. (1983: 172)

In building on his past work on the role of major powers within international institutions, in Production, Power and World Order, Cox argues that consensus formation takes place among the major advanced capitalist countries and that American agencies have a 
"dominant but not necessarily determining role" (1987: 259). Cox gives weight to the prominent role that international institutions play in "defining the ideological basis of consensus, the principles and goals within which polices are framed, and the norms of "correct" behavior (1987: 259). This became especially important with the breakdown of Bretton Woods in that the formal, legal framework for maintaining policy harmonization and consensus was no longer. As such, Cox writes, "ideology had to substitute for legal obligation" (1987: 259). In examining the international policy structure, Cox posits that the extent to which it is "evolved" or "definitive," varies and accordingly, the international policy structure should be "taken dialectally" (1987: 259). Given recent developments in the arena of international drug policy, we can perhaps understand this area of international policy making as being fluid rather than definitive.

William I. Robinson builds on Cox's framework of analysis in his book Promoting Polyarchy: Globalization, US Intervention and Hegemony. Robinson applies Gramsci's concept of hegemony to the transnational scale in that he posits that understanding globalization requires moving beyond traditional IR conceptions of the nation state. According to Robinson, the onset of modern globalization has brought with it the emergence of a transnational elite whose interests are more in-tune with those of their elite counterparts, regardless of nationality, than with the interests of the peasant class in their home state (1996: 22). Therefore, for Robinson, hegemony is something that is exercised in relations not only among nations but also among classes or groups at the transnational level (1996: 23). Robinson writes,

Gramscian hegemony involves the internationalization on the part of subordinate classes of the moral and cultural values, the codes of practical conduct and the worldview of the dominant classes or groups - in sum, the internalization of the 
social logic of the system of domination itself. This logic is imbedded in ideology, which acts as a cohesive force in social unification. (1996: 21)

According to Robinson, transnational elites operating at the level of the state act as agents of ideational hegemony, or diffusers of international norms. Robinson posits that it is the onset of globalization that has facilitated the onset of a truly global, hegemonic world order. Cox also speaks to this notion when he writes that a "stricter regime" than that which is applied to industrialized countries is applied to Third World countries (1987: 260). While Cox writes that third world elites do not "participate with the same effective status of top level elites in the formation of consensus," that the consensus in question "gains ideological recruits and places ideologically conditioned agents in key positions within Third World countries" (1987: 260). Cox writes, "the internationalization of the Third World state is externally determined and imposed, but it attracts internal allies and collaborators" (1987: 161).

\section{iii) Counter-hegemony and resistance}

In order to argue that the current developments are counter-hegemonic in nature, it is important to have a grasp on the Gramscian notions of counter-hegemony and resistance. Given that the project of establishing hegemony is never complete, as it requires the co-optation and participation of peripheral classes, hegemony in the Gramscian sense can be "challenged and resisted in the interlocking realms of civil society, political society, and the state," (Chin and Mittleman, 2004: 32). While Gramsci wrote about counter-hegemonic resistance prior to the onset of neoliberal globalization, and therefore, at the level of the state, we can apply his concepts to international arenas, 
as the compression of space and time with the onset of globalization has created new arenas for resistance (Chin and Mittleman, 2004: 34). This is very much evident in the issue at hand, in part because the drug problem is by its nature not one that can be managed at the level of the state. According to Adam David Morton, counter-hegemony can be very simply understood as an "attempt to create a new conception of the world at the ethico-political level whilst also transcending common economic-corporate interests," (2000: 261). Gramsci theorized that counter-hegemonic resistance could fall under one of two distinct types: 'wars of movement,' and 'wars of position,' (Worth and Kuhling, 2004: 35). While 'wars of movement,' can be understood as direct, collective action taken against the state (as exemplified by labour strikes or military coups), 'wars of position' involve non-violent action taken to hinder the capacity of the state to function (Chin and Mittleman, 2004: 32). Worth and Kuhling describe 'wars of position' as "subtle," and write that the main aim of the "war of position' is to "fundamentally contest the legitimacy of 'common sense' within an historic bloc by exposing and exploiting it weaknesses, thus destabilizing its hegemonic consent," (2000: 35). The idea of "wars of position' is helpful for understanding the new emerging discourse in the War on Drugs, in that statements made by prominent officials, reports issued by organizations like The Organization of American States (OAS), The Union of South American Nations (UNASUR) and The Community of Latin American and Caribbean States (CELAC), and policies implemented in countries like Bolivia, seek to destabilize hegemonic ideas surrounding drug control.

Interestingly, statements that we can understand as destabilizing to the hegemonic War on Drugs discourse have, in this instance, emanated from actors that we can 
understand as facilitators of ideological hegemony. This is very much the case in Guatemala, where right-wing President Otto Pérez Molina has been one of the most outspoken advocates on the international stage for the legalization of drugs. While Gramsci stresses the importance of 'organic intellectuals,' who we can understand as counter-hegemonic actors, for destabilizing hegemony, Polanyi posits that the state has a role to play in protecting the citizenry of a given polity from the devastation wrought by the un-regulated, free market. Unlike Gramsci who called upon left wing intellectuals to advocate for the interests of the marginalized classes, Polanyi theorized that the state has a role in ensuring the wellbeing of its citizenry in the context of free market expansion, ideology aside. For Polanyi, the move towards the free market brought with it the onset of a "double movement," whereby the "the fact that leaving the fate of the soil and people to the market would be tantamount to annihilating them," and so, we see the emergence of a countermovement to mitigate the "devastating effects of a self-regulating market," (1944: 131-132). According to Polanyi, the state has a role to play in countermovement, whereby in the name of social protection, the state should employ "protective legislation, restrictive associations and other instruments of intervention as its methods," (1944: 133). While in the Guatemalan case, President Pérez Molina is articulating a counterhegemonic discourse whilst still committed to the dominant neoliberal ideological hegemony of the day, we can understand his statements through the lens of Polanyi. If we can understand the current challenges that Guatemala faces in terms of the illegal drug trade as stemming from poverty related to neoliberal restructuring and repressive drug policies imposed by the United States, and the wellbeing of the Guatemalan populace is 
at stake given the levels of violence associated with the drug trade, the state, political ideology aside, has a role to play in mitigating the negative effects of the free market.

iv) Situating the emerging paradigm shift in the history of US- Latin American relations

Heavy-handed American involvement in the affairs of Latin American countries has characterized US-Latin American relations from the $18^{\text {th }}$ Century up until the present day. In the wake of decolonization in Latin America, the Monroe Doctrine stipulated that, as the major military power in the region, the United States could step in to 'protect the sovereignty' of its Latin American neighbours should European powers encroach on their territory. In effect, the Monroe Doctrine allowed for military ventures into Latin America whenever American interests were involved. In adopting the Good Neighbor Policy in the early 1930s, President Roosevelt vowed to put an end to American meddling in the sovereign affairs of Latin American countries (Grandin, 2006: 3). With the onset of the Cold War, however, a less overt but equally damaging style of American involvement in Latin American politics ensued (Grandin, 2006), as exemplified by the US-orchestrated coups that overthrew the democratically elected leaders of Guatemala in 1954 (Jacobo Arbenz) and Chile in 1973 (Salvador Allende). Both coups were orchestrated under the pretenses of hemispheric security and stifling the 'communist threat,' given that the leftist governance of both Arbenz and Allende were understood as presenting a direct threat to US (business) interests in the region for initiating such efforts as land redistribution to remedy the highly inequitable division of land in these countries at the time (Grandin, 2006: 42-43, 59). In referring to the coup in which Salvador Allende was assassinated, Cox writes, 
The Chilean coup and assassination of Allende... was a salient but by no means unique instance of how recalcitrant Third World governments are ultimately removed by violence if they do not conform to minimum standards of correct world-economy behavior (1987: 261).

We can situate these aggressive actions taken by the United States in the post World War II context of pax-Americana, whereby the United States acted as the unchallenged global hegemon and exported its methods of production abroad. As US based multinational corporations increasingly began conducting business in Latin America (given the abundance of cheep labour and lack of regulation), the US government stepped in to protect their interests - as was the case in Guatemala when Arbenz's plans for land reform threatened the economic interest of US agricultural firms.

As Russell and Tokatlian highlight in their article "Beyond Orthodoxy: Asserting Latin America's New Strategic Options Toward the United States," a variety of foreign policy positions in relation to the United States have been taken over time. In discussing the last twenty years more generally, Russell and Tokatlian argue that the 1990's can be characterized by policy heterogeneity in terms of Latin American foreign policies dealing with the United States (2011: 129). In the post Cold War context, Rossell and Tokatlian argue that Latin American governments moved ideologically closer to the United States, as exemplified by the region-wide adoption of neo-liberal policy and the move towards democratization under pressure from the IOs (2011: 135). By the end of the decade, however, we began to see more policy heterogeneity as disenchantment with the neoliberal policy thrust took hold of many countries, beginning with Venezuela, as exemplified by the election of Hugo Chavez in 1999, and spreading, primarily across the South American region, as we saw a continental shift to the left (Russell and Tokatlian, 
2011: 135-136). Over the course of the last decade, many scholars of Latin American politics have argued that we have seen the decline of the hegemonic power of the United States in the Latin American region, taking a decline in direct American intervention in the affairs of these countries as evidence of this.

Russell and Tokatlian understand the current context as one of structural change as a result of disenchantment with the neoliberal policies of the eighties and nineties, the dwindling power of the United States as the regional hegemon, and the emergence of other powerful actors in the region like Russia, China, India and South Africa (2011: 127128). The authors also lend credence to the emergence of strong transnational movements as facilitating the break down of American hegemony in the Latin American region (2011: 128). They further cite the United States' foreign policy focus on the Middle East as paving the way for the break down of American hegemony in Latin America (2011: 128). They argue that the shift in relative importance of the United States vis à vis other actors, to governments of Central, and especially South America, has opened spaces for policy innovation (Russell and Tokatlian, 2011: 127) This becomes clear when examining drug policy, in that over the course of the last five years we have seen the adoption of policies in countries like Bolivia and Uruguay that would have likely elicited economic or diplomatic sanctions from the United States a decade earlier.

Riggirozzi and Tussie's chapter in The Rise of Post-hegemonic Regionalism, entitled "The Rise of Post-Hegemonic Regionalism in Latin America" presents the argument that alternative regional structures in Latin America are "part of a complex set of alternative ideas and motivations affecting polices across the region" (2011:2). The piece explores the onset of a "post hegemonic" regionalism, highlighting that the current 
context allows for a reconfiguration of inter-American relations given the diminishing power of the United States in the region. Riggirozzi and Tussie posit that the formation of strong regional ties will work to create a strong regional bloc vis-à-vis the United States, opening spaces for new policy channels and reducing dependence on American trade and aid (2011). The formation of regional organizations like the Unión de Naciones Suramericanas $^{1}$ (UNASUR) is exemplary of this trend.

Finally, in Robinson's recent report for NACLA, entitled "Latin America in the New Global Capitalism," he examines the transformation of the Latin America region based upon processes of globalization. Robinson substantiates the claim that any given Latin American country is virtually unrecognizable compared to its character two decades ago in that globalization has "ushered in a new model of capitalist accumulation that has vastly restructured the region's productive base, and along with it, transformed the class structure, the social fabric, the political systems and cultural and ideological practices" (2012: 15). Robinson highlights six structural changes that have occurred in the Latin American region. First, Robinson highlights the reorientation of industry for industrial export, as exemplified by the growth in prevalence of export processing zones and maquiladoras (2012: 15). Second, we have seen major shifts in the way that agricultural production takes place as we have seen the entrance into Latin America of major agro-business firms, effectively displacing forms of subsistence farming (Robinson, 2012: 15). Robinson highlights that no country in Latin America has been spared from this phenomenon. Third, tourism has become increasingly significant in generating revenue (Robinson, 2012: 15). Fourth, finance and services have become

\footnotetext{
${ }^{1}$ Translation: Union of South American Nations
} 
increasingly transnational (Robinson, 2012: 17). Fifth, labour has come to be one of the region's major exports, with remittances becoming increasingly important to national economies (Robinson, 2012: 17). And, finally, we have seen a new round of extractivism as mining companies have sought out new reserves of valuable minerals in the context of rising commodity prices. (Robinson, 2012: 17).

While the shift towards neo-liberalism has generated vast amounts of wealth for some in the Latin American region, so too has it generated some of the highest levels of inequality the world has seen and plunged the most vulnerable deeper in to poverty. In highlighting these structural changes Robinson addresses neoliberalism's "crisis" in the region whereby he understands the failed promises of neo-liberalism as breaking ground for further transition in the region (2012: 18). Robinson posits that the failure of neoliberal governance to deliver on its promise of sustained growth and development for all classes has led to regional disenchantment with Washington Consensus policies, and the revival of left wing governance (2012: 18). Unlike other scholars however, writing in 2012, Robinson predicted this shift to the left would set the stage for further American intervention in the region, as exemplified by the American supported coup attempt against Hugo Chavez in 2002.

We have to understand the recent shift in drug policy discourse in Latin America, as occurring in a context in which we are seeing a decline in both the "hard" and "soft" power of the United States in the Latin American region. Shifting attitudes towards the United States, and international institutions perceived of as agents of American hegemony, coupled with hesitation of the current US administration under President Obama to directly intervene in ways that they would have in the past, have opened spaces 
for the revival of left wing governance in Latin America and new policy directions, and have facilitated the emergence of a counter-hegemonic approach to drug policy formulation in countries like Guatemala and Bolivia.

vi) Concluding thoughts

When we talk about the issue of drugs, we are talking about relations of production. The global prohibition regime lays out terms for the regulation of the production of narcotic substances. The construction of the global prohibition regime is fundamentally a reflection of US constructions of narcotic drugs and American, hegemonic power within international institutions. According to the neo-Gramscians, shifts in norms arise out of situations where we see shifts in the global distribution of power. If we understand these emerging shifts as occurring in a context in which we are seeing a breakdown of US hegemony in the Latin American region, according to Cox, we have a context in which we can see the emergence and diffusion of new international norms.

Robinson argues that globalization has brought with it the emergence of a transnational elite whose interests mirror more closely the interests of fellow elites rather than the interests of the peasant class in their given state. According to Robinson, statelevel elites act as agents of ideational hegemony and diffusers of international norms. Over the last couple of years we have seen dozens of prominent figures in international politics come forward and call for an end to the war on drugs. The fact that former heads of states, acting heads of state and former UN dignitaries have attached their name to the Report of the Global Commission on Drug Policy is indicative of a shift in the norms 
surrounding drug prohibition. If we understand international institutions as co-opting elites from peripheral countries into the dominant ideology, so too can we understand the statements made by, for example, ex-Mexican president Vicente Fox, current Colombian President, Juan Manuel Santos, and recent statements made by Guatemalan president Otto Perez Molina at the UN as indicative of this wider trend. While many have argued that organizations like UNASUR and CELAC are reflective of a post-hegemonic order emerging in Latin America, the fact that their positions closely mirrors that of the individuals attached to the Report of the Global Position on Drugs is exemplary of shifts occurring across ideological lines and the emergence of new global norms surrounding drug production and consumption. Further, increasingly, given shifts in the global balance of power, Latin American countries are able to contribute to the construction of global hegemony in a more significant way than in the past.

Finally, the new emerging discourse surrounding drugs is often underpinned by moral considerations. In the reports and documents of the OAS, The Global Commission on Drug Policy, CELAC and UNASUR as well as in statements issued by figures like Bill Clinton, Kofi Annan and Vicente Fox, a new approach to drug production and consumption becomes a moral imperative. Just as drugs were once constructed as an evil from which society needs to be protected against, now prohibition is increasingly being understood as detrimental to those very societies. Increasingly, we are seeing the emergence of 'transnational moral entrepreneurs' interested in deconstructing the global prohibition regime and organizational platforms dedicated to the task of deconstructing the global prohibition regime. 
In sum, while the liberal approach can help us to understand the mechanical process by which domestic ideals come to be international norms, the construction of drug consumption as a morally devoid behavior and the power that this idea has come to hold internationally, is best understood by an approach that takes into account global dynamics of power and conceives of hegemony beyond notions of "hard" power, but as being ideational. The neo-Gramscian approach can help us to understand why countries in the Latin American context adopted these norms and implemented related policies, despite the facts that these norms around consumption did not match domestic consumption patterns and ideas around drug consumption and that these policies have worked to exacerbate violence, destroy people's livelihoods, ban centuries old indigenous, cultural practices and have been met with significant resistance. Further, the neo-Gramscian approach and its discussion of transnational elites and shifting power relations, can best explain why we are seeing the emergence of new international norms surrounding drug policy, based on the activities of transnational moral entrepreneurs that we can also classify as being members of the transnational elite. Finally, Polanyi can help us to understand why this shift is occurring across the ideological spectrum.

\subsection{Methodological considerations}

While this project will rely heavily on the secondary War on Drugs literature, I will take speeches and policy documents as evidence of an emerging shift in the trajectory of the War on Drugs. This project will employ critical discourse analysis, in analyzing policy and speeches. While we cannot understand critical discourse analysis as distinct, singular method, we can say that it rests upon several core assumptions. Above 
all, critical discourse analysis aims to unearth relations of power that are embedded and encoded in language and discourse (Machin and Mayr, 2012: 2). Critical discourse analysis examines why some narratives come to be dominant and tries to understand language, meanings and texts as sites of power (Machin and Mayr, 2012: 2). Critical discourse analysis understands language and texts as social constructs and ideological instruments that can be employed in order to purport certain norms and assumptions (Machin and Mayr, 2012: 2). This being said, language isn't understood as being powerful in and of itself. Rather, actors give power to language (Meyer and Wodak, 2001: 10). Accordingly, critical discourse analysis is as much about what isn't being explicitly said as what is. This approach seeks to expose what is taken for granted, neutral or normal in a given society and tries to debunk that neutrality (Machin and Mayr, 2012: 3). Critical discourse analysis concerns itself with issues of "gender, ethnicity, cultural difference, ideology and identity and how these are both constructed and reflected in texts" (Van Dijk, 1993: 250). It understands society and language as being mutually constitutive - while language shapes society, society in turn shapes language (Meyer and Wodak, 2001: 4). For the most part, critical approaches to discourse analysis move away from empirics and reject the notion that we can produce objective knowledge surrounding discourse. Finally, critical discourse analysts stress self-reflexivity in conducting their research (Paltridge, 2006: 186).

This project will look primarily to speeches and policy documents that have emerged over the course of the last five years, in that it is only very recently that this new discourse has emerged. The choice of cases is reflective of where I perceive the shift to be most significant and as contributing to the construction of new norms surrounding 
drug production. While in the Latin American context, when examining the War on Drugs, it may seem strange to exclude the cases of Colombia and Mexico, as the detrimental affects of the Drug War are more pronounced in these two countries than perhaps anywhere else in the world. Given the scope of this project and that the shift away from the old orthodoxy has not occurred to the degree in Colombia and Mexico that it has in Guatemala and Bolivia, I have chosen to exclude these two cases. In terms of the documents to be analyzed, it is important to look to texts that have been produced by actors and agencies that we can understand as constructors and maintainers of ideational hegemony in the neo-Gramscian sense as well as organizations and actors that fall outside of these parameters, in order to come to an understanding that an array of actors and agencies are contributing to a paradigm shift in the realm of drug policy.

\subsection{Outline of this thesis}

In the second chapter, this thesis will explore the orthodox discourse and how it came to be solidified in international law in the forms of the 1961 Single Convention on Narcotic Drugs and the subsequent 1988 UN Convention Against Illicit Traffic in Narcotic Drugs. Then, in the third chapter, this project will turn to the new emerging discourse and look to the statements and policy positions of prominent individuals in global politics and organizations to argue that we are seeing the emergence of a counterhegemonic approach to managing the drug problem. Specifically, chapter three will examine the reports of the Global Commission on Drug Policy and the Organization of American States (OAS), as well as the policy positions of UNASUR as well as the 
Comunidad de Estados Latinoamericanos y Caribeños $^{2}$ (CELAC). The fourth chapter will turn to Bolivian context, to examine the Morales government's strategies of Control Social $^{3}$ and diplomacia de la $\operatorname{coca}^{4}$, with specific focus on the recent $\mathrm{UN}$ special dispensation that deems coca chewing a legal practice within the confines of Bolivia's borders, to illustrate both the emergence of counter-hegemonic policy pertaining to drugs emanating from a left leaning government and shifts at the level of international governance. In the final chapter this project will turn to the case of Guatemala. While in the Guatemalan context we have not seen concrete policy changes in the direction of a counter-hegemonic management of the drug problem, this project will look to the statements made by Guatemala's right leaning President, Otto Pérez Molina, to illustrate that we are seeing clear shifts in thinking emerging from a right leaning government.

\footnotetext{
${ }^{2}$ Translation: Community of Latin American and Caribbean States

${ }^{3}$ Translation: Social Control

${ }^{4}$ Translation: Coca diplomacy
} 


\section{Chapter: Understanding the orthodox, War on Drugs discourse}

"We must wage what I have called total war on public enemy number one in the United States," President Nixon told a group of reporters in 1972. The "public enemy number one" that Nixon was referring to was neither the Communist threat nor the threat that stagflation was beginning to pose to the continued economic dominance of the United States on the international stage. Rather, the enemy that Nixon was referring to was the threat posed by "the problem of dangerous drugs." In the American context, illicit drugs were, and to a certain extent remain to be understood as being to blame for a whole host of social ills - from absentee fathers and divorce to gun violence. With the exception of Jimmy Carter (Galen Carpenter, 2003: 16), president after president has employed this discourse in justifying funneling billions of dollars into strategies to combat drug production and consumption. In a September 1981 address given to American police chiefs, Ronald Reagan stressed the need for "a foreign policy that vigorously seeks to interdict and eradicate illicit drugs, wherever cultivated, processed, or transported," marking the shift towards a more militarily interventionist phase in the history of the War on Drugs. George H. W. Bush echoed his predecessor's statements in an address from the Oval Office in which he called upon his fellow Americans to wage "an assault on every front," in reference to the drug problem. While Clinton won the presidency on a platform that would try to stem the skyrocketing rates of incarceration associated with the Reagan and Bush years, supply side strategies, centered on Latin America, remained as much a part of the War on Drugs arsenal under the Clinton administration as ever (Galen Carpenter, 2003: 53-55). Despite being busy with a host of

other military ventures, George W. Bush also built on his predecessors' legacy, as 
exemplified by his April 2001 announcement of the Andean Initiative, an \$882 million dollar effort to bolster democratic institutions and support counter narcotic efforts in the Andean region (The Presidency Project, 2001):

Too many people in our hemisphere grow, sell, and use illegal drugs. The United States is responsible to fight its own demand for drugs. And we will expand our efforts to work with producer and transit countries to fortify their democratic institutions, promote sustainable development, and fight the supply of drugs at the source.

The open-ended effort to combat drug use at the source has cost the United States an estimated \$2.5 trillion US (Wood, 2012). In Latin America, the War on Drugs effort has entailed direct American military intervention, the disbursement of American funds directed at various programs and militaries to carry out War on Drugs efforts, the disbursement of American foreign aid being contingent upon active participation in the War on Drugs effort, and sanctions for non-compliance with US anti-drug objectives (Galen Carpenter, 2003). In countries like Bolivia, Peru, Colombia and Mexico, the US imposed policies have wrought much devastation.

\subsection{The construction of drug use as deviant}

Humans have always, and likely will continue to consume psychoactive substances. Prior to the $20^{\text {th }}$ century, the production, distribution and consumption of substances like marijuana, opium and cocaine was, for the most part, unregulated (Nadelmann, 1990: 503). As doctors came to better understand the addictive properties of such substances, and as alternate pain remedies, like aspirin, became more widely available, the consumption of psychoactive substances became increasingly constructed and understood as a deviant and morally devoid social behaviour (Nadelmann, 1990: 
505). Of course, narcotic substances in and of themselves are inanimate objects and are only problematic should they be ingested, and so concerns surrounding drugs are fundamentally about who it is that is ingesting them (Reinarman, 1994: 97). The move towards prohibiting the production and consumption of narcotic substances in the United States occurred in a context in which the temperance movement wielded considerable influence. Prohibitionists were eventually successful in achieving a national ban on the sale of alcohol in the United States between 1920 and 1933. Craig Reinarman attributes the success of the temperance movement in the United States to the international turbulence of the early $20^{\text {th }}$ Century (1994: 97). He writes,

In the tumultuous period leading up to prohibition, there were revolutions in Russia and Mexico, World War I, massive immigration and impoverishment, and socialist, anarchist and labour movements, to say nothing of increases in routine problems such as crime. (1994: 97)

In the early twentieth century, similar movements emerged, with varying degrees of success, in Canada, the United Kingdom and the Nordic countries. The success of these various temperance movements, albeit short lived, is reflective of a context that can be described as being characterized by a degree of moral proselytizing (Nadlemann, 1990: 505-507). Shifts in attitudes towards drug use in the United States around the turn of the century can also in part be attributed to changing patterns of drug use (Nadlemann, 1990: 505-507). While drug addiction had previously been associated with self-medicating, wounded war veterans, intent on relieving their seemingly 'legitimate' physical and emotional pain, increasingly, drugs were being taken for pleasure and in public by urban youth (McAllister, 2000: 17). William B. McAllister writes,

Drug use of that type symbolized for many the social deviancy and moral deficiency inherent in increasingly public displays of vice. In the minds of 
contemporaries, a perceived decline in traditional morality, especially among the underclass, merited a more punitive response. (2000: 17)

Of course, the notion that certain narcotic substances are a detriment to one's health is not divorced from reality, and, as doctors became increasingly aware of the health problems associated with the overconsumption of specific drugs and alcohol, a degree of concern was certainly warranted. Where a disconnect continues to persist between the popular discourse and material reality however, is in constructions of what types of people are partaking in this behaviour. This discourse was, and remains to be one that is underpinned by ideas about race and class.

Many have argued that the prohibition movement in the United States achieved much of its success by playing into mainstream associations of drug and alcohol abuse with minority groups (Nadlemann, 1990: 507). In writing about drug regulation in the early 1900s, Ethan Nadlemann summarizes early associations between drug consumption and race as follows:

Many Protestant Americans identified alcohol and its ills with the fearsome flow of millions of Catholic and Jewish immigrants into the United States... The first anti-opium laws... were directed at the smoking of opium, which was associated with Chinese immigrants and deviant whites. Their use of the drug was perceived as symbolic of the immigrants' decadence and as a potential weapon that could be used to undermine American society. In the South, the white majority feared that cocaine use among blacks might cause them to forget their assigned status in the social order. And in the West and Southwest, the association of marijuana with Mexicans provided a powerful impetus to legislation effectively outlawing the substance. (1990: 506-507)

This mainstream association of drug consumption with racial minorities in the United States has persisted into the current day, despite the fact that the statistics on drug consumption repeatedly tell us that this is not the case and that whites consume drugs at the same rates, if not with more frequency, than those of other racial groupings (Drug 
Policy Alliance, 2014: 1). Although these stereotypes are not grounded in truth, they have severe implications for racial minorities - especially young, black men. While blacks comprise $13 \%$ of the American population and consume drugs at roughly the same rate as the white population in the United States, they comprise $45 \%$ of those incarcerated for drug offenses (Drug Policy Alliance, 2014: 1), reflecting a blatant disconnect between the statistics and the stereotypes. In the United States, as is the case elsewhere in the Western world, regulating drug consumption has been, and remains to be, a means of regulating racialized and marginalized groups in society, often painted in a language of benevolent paternalism.

Racial and class based associations aside, the problem of "dangerous drugs" has often been used as a scapegoat for a wide array of issues, especially in American society (Reinarmen, 1994: 95). Despite the fact that countless studies show that the detrimental effects of marijuana consumption to one's health is on par or less than that of consuming too much alcohol or too many cigarettes, in the 1960 's, moral entrepreneurs framed marijuana as the "drop out drug," responsible for, as Reinarman writes, "leading American youth to rebellion and ruin" (1994: 95). Many "tough on drug" presidents have pointed to crime, gun violence (Reagan, 1981) and even teen pregnancy (Bush, 1988) as symptoms of a society riddled with drug dealers and abusers rather than, say, poverty. Reinemen argues that by pointing fingers at the monolithic category of 'drugs' politicians can "deflect attention from other, more systemic sources of public problems for which they would otherwise have to take some responsibility" (1994: 97).

This construction of drug consumption as a morally deviant behavior, its subsequent associations with specific racialized and class based groups in society and the 
linking of drug abuse to a variety of social ills has created fertile ground for "moral entrepreneurs" in the United States to argue for the sustained prohibition of narcotic substances and the adoption of measures to combat their illegal distribution. If we understand the extent to which these views have become engrained in American society and that this discourse has been employed by prominent political figures and the mainstream media alike, coupled with the transnational nature of drug production and distribution, we can come to understand why American moral entrepreneurs pursued the implementation of a transnational prohibition regime. Given the prominent position that the United States plays in international institutions, we can also understand how drug prohibition came to be the international norm.

\subsection{The global prohibition regime}

Given that the production and consumption of illicit drugs is by its nature not a problem that can be solved within the confines of a single nation state, transnational negotiations on how to manage this issue began in the early 1900's (McAllister, 2000: 11-39). Invasive US efforts to stem drug production at the source have been lent legitimacy by international law. More specifically, supply side strategies have been justified based on the 1961 UN Convention on Narcotic Drugs. Many have presented the argument that the "no-nonsense" international convention would come to characterize the global approach to drug control over the course of the next five decades. Of the convention, Count the Costs, an emerging collaborative project of various NGOs that aims to highlight the unintended costs of the war on drugs, has said: "50 years ago the 1961 UN Single Convention on Narcotic Drugs cemented an enforcement-based 
approach into an international legal framework that remains largely unchanged to this day" (Murkin et al, 2012: 8). Scholars have grouped together the 1961 convention with the 1971 Convention on Psychotropic Substances and the 1988 Convention against Illicit Traffic in Narcotic Drugs and Psychotropic Substances to form what they refer to as the "global drug prohibition regime" (Bewley-Taylor, 2002: 172).

In examining the global drug prohibition regime it is important to bear in mind that international institutions like the United Nations are composed of independent member nations with a myriad of interests and varying degrees of power. Cox understands international institutions as being a facilitator of American ideational hegemony in the post World War Two context. Cox writes, “...International organization functions as the process through which the institutions of hegemony and its ideology are developed" (1983: 172). As previously outlined, Cox premises his argument that international institutions act as agents of American ideational hegemony on the following five points:

(1) they embody the rules which facilitate the expansion of hegemonic world order; (2) they are themselves the product of hegemonic world order; (3) they ideologically legitimate the norms of world order; (4) they co-opt the elites from peripheral countries and (5) they absorb counter hegemonic ideas. (1983:172)

American corporate interest in the formulation of the 1961 convention becomes quite clear when one looks at article 27. While the convention deems the traditional Andean practice of chewing coca leaves an illegal activity, despite the fact that the unprocessed leaves themselves have no hallucinogenic effects and chewing them is helpful in curbing hunger, nausea and altitude sickness in the low income, high altitude Andean region, article 27 of the 1961 Convention permits, “... the use of coca leaves for the preparation of a flavouring agent, which shall not contain any alkaloids, and, to the extent necessary 
for such use, may permit the production, import, export, trade in and possession of such leaves" (1961: 14). Interestingly, in 1961 when the convention was ratified, one of the only companies utilizing coca as a flavouring agent was Coca Cola (Stolberg, 2011: 132). We can take article 27 as indicative of the strong hand that the US government has in international institutions like the United Nations and evidence of, as Cox argues, the United Nations being an "institution of hegemony." A further reflection of American prominence in the construction of the 1961 Convention is the types of substances that were to be regulated. Of course, alternate constructions of various substances exist. Nadelmann posits that had Middle Eastern countries been at the forefront of drug regulation, alcohol would likely be prohibited, whereas had Andean countries played a powerful role in the formation of the convention, we likely would have seen a regime that allowed the growing and chewing of coca (1990: 511).

Ethan Nadelmann stresses the prominent role of the United States in the construction of the global prohibition regime. If we look to the liberal literature and employ Finnemore and Sikinck's three-stage framework, we can understand the first stage of "norm emergence" as emanating primarily from the United States. In the context of the early 1900's and the move towards drug prohibition, primarily missionaries, as well as the white, upper-middle class U.S. population represented the "norm entrepreneurs." The white upper middle class population was sympathetic to the cause of the missionaries and motivated by "Christian moralism," as well as fears about the perceived negative implications drug use would have for society, both in terms of crime rates associated with drug consumption and declining economic productivity based on the perceived widespread drug use of the lower classes (Nadlemann, 1990: 506). The success 
of the American moral entrepreneurs in constructing an international, anti-drug regime however, was grounded in a general lack of opposition from the international community. In part, this can be attributed to the United States' position as the un-challenged global hegemon in the post-war period (O'Meara, 2010: 35-38). Further, elites in many countries shared the sentiments of those Americans pushing for the prohibition of drugs, whereby drug use was associated with deviant behaviors and certain racial and income groups in society (Nadelmann, 1990: 510).

Emily Crick argues that the 1961 Convention was markedly different from the previous treaties that it sought to consolidate, both in its language and in its aims, to prohibit rather than regulate drug production and consumption (2011: 407). In terms of language, Crick writes,

The use of the word 'evil' in the Single Convention is exceptional as no other international convention describes the activity it seeks to prevent in such terms. Furthermore, such language has created the space for policies that themselves threaten human rights and human security in the name of fighting 'evil.' (2011: 408)

Crick is referring to the language used in the preamble of the convention whereby addiction is presented as "a serious evil" and the parties are "conscious of their duty to prevent and combat this evil" (1961: 1).

James E. Hawdon posits that drug policies can fall into either of two categories: punishment or rehabilitation (2001: 424). According to Hawdon the punishment model understands drug use as the individual, willful choice of the user and accordingly, that that individual should be punished for their violation of the law (2001:424). Conversely, the rehabilitation approach understands drug users as being not in control of their drug habits and victims of a disease (Hawdon, 2001: 424). Policy that stems from this 
understanding of drug use takes a markedly different form from that of the punishment model and is exemplified by harm reduction policies that have been recently implemented in a variety of OECD countries (Hawdon, 2001: 424). The American approach to domestic drug policy can largely be categorized as falling under the punishment model, exemplified by the unprecedented number of individuals populating the American prison system on drug charges. Given the prominent position of the United States in international institutions and the role that the United States plays as a propagator of international norms, it is of little surprise that the 1961 Convention can be classified as falling under the punishment model of policy formulation as well. While the 1961 Convention allows a measure of flexibility for states to formulate their own domestic approach to drug control, it calls on signatories to,

Adopt such measures as will ensure that cultivation, production, manufacture, extraction, preparation, possession, offering, offering for sale, distribution, purchase, sale... and any other action which in the opinion of such party may be contrary to the provisions of this Convention, shall be punishable offences when committed intentionally, and that serious offences shall be liable to adequate punishment particularly by imprisonment or other penalties of deprivation of liberty. (1961: 18)

Meanwhile, in the 51-article convention, only in article 38 does the convention make quick mention of provisions for treatment and education (1961: 19). This punishment approach to drug policy formulation is also quite clear in the 1988 UN Convention Against Illicit Traffic in Narcotic Drugs, as it called on signatories to establish criminal offenses under domestic law for both the illicit trafficking and the illicit demand of drugs (1988: 3). Unlike the 1969 Convention, the 1988 Convention made no mention of measures for treatment, education or harm reduction. This is exemplary of the hand that 
IOs have in structuring international norms, as outlined by both the liberal and the neoGramscian theorists.

Finally, also evident in both conventions is an emphasis on limiting supply rather than reducing the demand for narcotic substances. This is very much emblematic of the prominent role that the United States played in the formation of the convention, in that it fits neatly into the dominant line of American thought whereby domestic drug consumption is fundamentally a symptom of the flow of drugs into the United States from other countries, and therefore the solution to the drug problem lies outside American borders (Crick, 2012: 410). The 1961 Convention focuses heavily on the cultivation of plants for drug processing and stresses supply side strategies for reducing drug consumption. This is evident in articles 21 to 29 of the convention (1961: 11-14), which all focus in some way on limiting supply of various substances. Given that the convention consists of only 51 articles, and that the first twenty articles deal predominantly with laying out definitions, administrative considerations and the roles for the Commission on Narcotic Drugs of the Economic and Social Council and the International Narcotics Control Board, we can understand that much emphasis was placed on reducing supply. This emphasis on supply control is evident in 1988 Convention as well. Not only does the convention include provisions centering around eradication, ${ }^{5}$ the convention also requires its signatories to submit reports to US Congress concerning how far they had come in meeting their objectives as outlined by the 1988 Convention (Crick, 2012: 411).

\footnotetext{
${ }^{5}$ See Article 14, page 14
} 


\subsection{The Securitization of Drugs}

Emily Crick applies the Copenhagen School's securitization framework to the global drug prohibition regime in order to explore the internationalization of what she calls the 'drugs as threat discourse.' Crick posits that the United States has been central to the internationalization of the 'drugs as threat discourse,' given their prominent position in the formulation of international drug policy. For Crick, the process of securitization began with the ratification of the 1961 Convention in that, as previously touched on, the language of the Convention was markedly different from that of previous international agreements. Crick writes,

The developing discourses surrounding drugs consistently rely on the construction of drugs, drug users, drug producers and drug traffickers as 'the antagonistic drug other.'... This regime articulated the idea that the fulfillment of the global 'self' was being hindered by the 'antagonistic drug Other' by creating the idea of 'mankind' (Single Convention, 1961) as the global 'Self' carrying out the humanitarian endeavor to rid the world of the drugs threat, the hegemonic discourse was strengthened and, therefore, the institutionalization of policies to negate these threats... became strengthened... Such language has created the space for policies that themselves threaten human rights and human security in the name of fighting evil. (2012: 408)

Crick understands the fact that $96 \%$ of countries are signatories to the 1961 Single Convention as being exemplary of the universality of this discourse (2012: 408). While upon ratification in 1961, the discourse was characterized by religious undertones, as exemplified by the use of the word evil, Crick highlights a shift in discourse towards analogies of 'war,' beginning with Nixon and consolidated under Reagan (2012: 411).

While we can argue that the 'drugs as threat' discourse emerged with the ratification of the 1961 Convention, this discourse became especially prevalent under the Reagan administration, whereby Reagan would often repeatedly refer to the problem of 
drug trafficking as a "national security threat" (Galen Carpenter, 2003: 29). Under the Reagan administration strong links were drawn between drug trafficking and terrorist activity (Crick, 2012: 411). Terms like "narco-terrorist" and "narco-communist" became fixtures of the American neo-conservative popular lexicon (Galen Carpenter, 2003: 49). Further, Reagan, and the leaders that preceded him, often made reference to the threat that drug trafficking posed to democratic governance in the Latin American region should a given state's government and institutions be infiltrated by drug traffickers. Of course, there is truth to the notion that drug cartels in, for example, Colombia, Guatemala and Mexico have been and have become very powerful in relation to the state. The physical security threat posed by drug trafficking to the United States however is minimal at best. Violence associated with the drug cartels in Northern Mexico has been largely contained within Mexican borders. Further, one would be hard pressed to find a terrorist attack on US soil emanating from groups that are funded by Latin American drug money. Nevertheless, under successive US presidents, drugs became constructed as a threat to national security.

The 'drugs as threat' discourse is very much evident in the National Security Decision Directive \#221 (NSDD 221), which came into effect in 1986. The document makes direct links between drug trafficking and terrorist groups, discusses the "inevitable rise in violence" associated with drug trafficking and the threat it poses to "the integrity" of democratic governance (1986: 2). About the directive, Galen Carpenter writes "although portions of the directive remain classified, it is clear that the military and intelligence portions of the document were deemed most important" (2003: 29). This is 
evident on the last page of the directive, where actions that are outlined to be taken by the president include,

- Full consideration of drug control activities in our foreign assistance planning,

- An expanded role for U.S. military forces in supporting counter-narcotics efforts

- Additional emphasis on narcotics as a national security issue in discussions with other nations.

- Greater participation by the U.S. intelligence community in supporting efforts to counter drug trafficking (1986: 6)

Galen Carpenter argues that the issuance of the NSDD 221 provided supporters of the War on Drugs with new ground to stand on in their calls for increased military action in the face of the drug threat (2003: 31). Many have drawn links between the language used in the NSDD 221 and the subsequent 1988 UN Convention Against the Illicit Traffic in Narcotic Drugs and Psychotropic Substances. Crick highlights that the notion propagated in the NSDD 221, that drug trafficking constitutes an existential threat to the state, was articulated at the international level with the ratification of the 1988 UN Convention, representing the internationalization of this discourse (2012: 411). The link between drugs and security is made quite clear in the preamble to the 1988 convention:

... Recognizing the links between illicit traffic and other related organized criminal activities which undermine the legitimate economies and threaten the stability, security and sovereignty of states, Aware that illicit traffic generates large financial profits and wealth enabling transnational criminal organizations to penetrate, contaminate and corrupt the structures of government, legitimate commercial and financial business and society at all its levels... (1988: 1)

The similarity in language between the NSDD 221 and the 1988 Convention, are exemplary of the process outlined by liberal theorists by which domestic norms evolve into international norms, often through channels like the UN. By securitizing the issue of drug trafficking, the issue was moved outside the realm of domestic politics and as a 
consequence, beyond the grasp of voters (Crick, 2012: 413). Further, it placed the issue higher on both domestic and international agendas. Finally, by constructing the threat posed by drugs in such dramatic terms, it allowed for responses to a "humanitarian issue," that in fact worked to violate facets of international human rights law and fostered violence in the name of fighting this 'evil' (Crick, 2012: 408). Painting the problem in such terms strengthened the hegemonic power of the discourse.

\subsection{Policy outcomes - In the US and abroad}

Rather than focusing drug policy on reducing consumption, and therefore demand, domestically, prominent powers in international drug control, like the United Kingdom and the United States, have repeatedly emphasized supply control as the key strategy in the formulation of international drug policy. McAllister writes that "the logic of supply control suffused all drug negotiations" beginning with the 1931 Conference on the Limitation of Manufactured Drugs in Geneva and continuing up until this day (2000: 3). We can understand supply control as the dominant approach to reducing drug consumption internationally over the course of the late $20^{\text {th }}$ and early $21^{\text {st }}$ century - or, the international norm. The premise is quite simple: by eliminating drug production you will eliminate drug consumption. The attempt to put this premise into practice, however, has been fantastically complicated, expensive, and destructive and has seen little success in terms of reducing either production or consumption.

Drug production and consumption sit around the same levels as they did thirty years ago, when the most invasive phase in supply control of the War on Drugs began, while the cost of drugs on the streets has generally decreased (Werb et al, 2013) and 
violence associated with drug production and trafficking has increased. In the Latin American context, the War on Drugs has involved direct American military intervention, the linking of American foreign assistance to participation in the War on Drugs effort, sanctions for non-compliance, and the funding of various programs and militaries to carry out War on Drugs efforts. In the Andes, for example, the forced eradication of coca in one of the poorest regions in the world left hundreds of thousands of farmers without the capacity to support themselves - eradication efforts coincided with the Latin American debt crisis and the push towards draconian neoliberal reform, leaving poor cocaleros (coca growers) with few paths of alternative employment and little if any social safety net to rely on (Kohl and Farthing, 2006: 65-70). Further, there are plenty of examples of torture being used as an instrument of the War on Drugs as a means of extracting information (Kohl and Farthing, 2010: 198). Popular protest to War on Drugs policy has often been met with harsh repression often resulting in the deaths, injury and arbitrary arrests of citizens.

While the "War on Drugs" discourse began under Nixon, it was under President Reagan that the initiative became militarized, increasingly invasive and truly international in scope (Galen Carpenter, 2003: 21). Reagan's presidency coincided with, or as some argue cultivated, heightened moral panic and hysteria surrounding drug consumption in the United States (Hawdon, 2001). Accordingly, under Reagan we saw unprecedented levels of spending on anti-drug efforts. While the federal anti-drug budget sat at $\$ 1.2$ billion in 1981 , in 1989 it was over $\$ 5.7$ billion - more than a $400 \%$ increase in spending (Galen Carpenter, 2003: 34). Nixon's efforts had focused primarily on opium producing countries like France and Turkey, as well as, although to a lesser extent, 
marijuana trafficking routes through Mexico (Galen Carpenter, 2003: 14-15). In the context of the Vietnam War, military resources for anti-drug efforts under Nixon were sparse. However, in 1971 when reports were released that outlined widespread heroin addiction amongst American soldiers fighting in Vietnam, US anti-Heroin efforts in opium producing countries were ramped up (Galen Carpenter, 2003: 15). Reagan's international efforts marked a geographical shift, as they were directed more at stifling the production of cocaine and accordingly saw resources channeled towards coca growing countries like Ecuador, Peru and Bolivia and cocaine processing countries like Colombia (Galen Carpenter, 2003: 20-23). While, his can be attributed to changing patterns in drug use that saw more Americans consuming cocaine, primarily this shift was a symptom of heightened moral panic, in that the shifts in patterns of drug use were not so substantive that they warranted such massive increases in resources being directed at anti-drug efforts (Galen Carpenter, 2003: 21). The Reagan administration integrated objectives surrounding drug control into all aspects of foreign policy, as outlined by the NSDD 221:

The secretary of state and the administration of aid should ensure that narcotics control objectives are fully integrated into foreign assistance planning efforts. The planning process should include consideration of programs designed to assist foreign governments achieve effective control objectives and should be guided by the principles of controlling crop production and targeting trafficking at the source and in transit (1986: 3).

The international strategy of the Reagan administration was premised on eradication projects (occasionally involving the aerial spraying of fields with harmful chemicals to kill coca plants, endangering the health of farmers and killing any other crops that may have been growing alongside coca plants), the interdiction of drug trafficking routes to 
seize narcotic substances in transit, and programs to encourage crop substitution (although, many point to the fact that crop substitution programs were often either underfunded and not followed through)(Galen Carpenter, 2003: 24). While drug consumption remained relatively stagnant in the United States, Reagan's approach to reducing consumption was markedly different from his predecessors.

Most governments in Latin America showed little initial enthusiasm for Regan's supply side policies (McAllister, 2000: 25). Attitudes about marijuana and coca differed substantially from those in the United States (McAlliser, 2000: 25). Few, if any, countries in the region faced challenges related to widespread substance abuse, and activities like coca cultivation made up an integral part of the economy in cash strapped, developing countries (McAllister, 2000: 25). Many governments in the region were in fact hesitant to partake in Washington's policy proposals and saw them as primarily self-servant and hardly to the benefit of their constituencies (McAllister, 2000: 25). This being said, all countries in the Latin American region were signatories to the 1961 Convention, and as such, were obligated by international law to abide by its principles. This is in line with Robinson's notion of transnational elites whereby the ruling class in peripheral countries are more likely to share the sentiments of elites in industrialized countries than those of the peasantry in their given state. Because of the importance of coca cultivation and chewing in the Andean region however, a few governments in countries like Bolivia and Peru moved towards an outright ban of coca cultivation (Galen Carpenter, 2003: 23), despite the fact that it was deemed a schedule 1 substance in the 1961 Convention and its cultivation was therefor illegal according to international law. The exception to this was during Hugo Banzer's second presidency in Bolivia. While during his first presidency 
from 1971-1978, he had allowed coca cultivation (and shared a close relationship with drug producing and trafficking organizations in the South American region), during his second presidency, succumbing to US pressure, Banzer implemented one of the most draconian coca eradication schemes the world has ever seen, eventually proclaiming that Bolivia was coca free (albeit this only lasted for a short time)(Draper et al, 2009: 203). This is exemplary of Cox's notion that while the internationalization of the third world state is "externally imposed," (as the resistance movement that emerged out of this context in Bolivia would suggest that the policies imposed were not in line with public opinion) it gains internal "allies and collaborators," who under pressure from both the IOs and the US government, adopt the international, mainstream consensus (1987: 161).

Some have argued that the militarization of the War on Drugs had much to do with the easing of Cold War tensions. Given that the massive American military bureaucracy was essentially devoid of focus in the absence of the threat that the USSR had once posed, the American military industrial complex was in need of a new channel for its resources (Galen Carpenter, 2003: 42-47). Many have argued that the ramped up effort to stifle drug production undertaken by George H. W. Bush effectively worked to fill the vacuum left behind by the fall of the Berlin wall. Galen Carpenter writes,

As the Cold War came to an end, members of the national security bureaucracy, those who profited from a large military establishment, and cheerleaders for "inspiring" national crusades all began to see the drug war as a useful substitute. (2003: 43)

While the military had once been hesitant to engage in efforts relating to the War on Drugs, in the absence of other external threats, attitudes shifted significantly (Galen Carpenter, 2003: 44). What followed was the most militarily invasive phase of the War 
on Drugs in Latin America. George H. W. Bush built on his predecessor's supply control legacy in spearheading the $\$ 2.2$ billion Andean initiative to reduce coca cultivation in Bolivia, Ecuador and Peru and invaded Panama to overthrow President Noriega on the pretenses that his regime was friendly to drug traffickers (Galen Carpenter, 2003: 33-42). While Bill Clinton did not embrace the "tough on drugs" discourse of his predecessors, and was elected on a platform to reduce the ballooning rates of incarceration associated with (often minor) drug offenses, supply side strategies for coca eradication remained as much, if not more of a part of the War on Drugs arsenal as ever (Galen Carpenter, 2003: 52- 55). The Clinton administration's most significant initiative was Plan Colombia, a $\$ 7.5$ billion plan to reduce the flow of cocaine out of Colombia (Galen Carpenter, 2003: 59). Although Plan Colombia outlined alternative development projects in an effort to reduce cocaine production, the initiative primarily involved aid to the Colombian military, both in resources and expertise, in order to stifle the power of the Colombian cartels (Galen Carpenter, 2003: 59-60). In the same vein as his father President George W. Bush initiated his own Andean Initiative to combat drug production and trafficking in the Andean region (The Presidency Project, 2001). Each of these initiatives has been justified by the 'drugs as threat' discourse. These international initiatives have been painted as paternalistic. The threat that drugs and drug trafficking pose go beyond that of moral considerations or health concerns; rather, drug trafficking degrades democratic institutions and poses a threat to international security and human rights. In the discourse, drug traffickers become equated with terrorists. Constructing the threat in such a way, and premising international intervention on international laws that are understood as 'legitimate,' American administrations had effectively created the 'legitimate' grounds 
for intervention into the sovereign affairs of Latin American countries. In constructing the threat that drug trafficking posed in such dramatic terms, drastic policy responses that were often accompanied by human rights violations and worked to exacerbate violence associated with the drug trade, were put into place with very little opposition from other governments in the industrialized world, officials at the United Nations or even the governments of the countries in which the United States Drug Enforcement Agency (USDEA) was primarily operating. While it is not within the scope of this project to offer a full synopsis of American supply side strategies in the War on Drugs context, the context specific, adverse affects of American supply side initiatives will be discussed at greater length specifically in the Bolivia case study.

\subsection{Waging the drug war in the neoliberal context}

Interestingly, taking a prohibitionist and internationally invasive stance to the regulation of narcotic substances, can be seen to stand in tension with the neoliberal economic orthodoxy embraced by the Reagan administration and his successors. While neoliberal thought calls for a curtailment of the structures of the state, the success of a prohibition regime is contingent upon regulation and intervention. The very notion that we should limit the individual's freedom to ingest substances like cocaine, marijuana and heroin, also could be interpreted to stand in direct tension with the liberal theory that Western governments claim to subscribe to. John Stuart Mill wrote that while we can place parameters upon individual freedom that prohibits the individual from inflicting harm upon another individual, self-harm is not sufficient grounds for government intervention (1859: 21). While the United States, alongside international 
institutions like the World Bank and IMF, were aggressively pushing neoliberal restructuring in many Latin American countries in the wake of the Latin American debt crisis, so to were they advocating for the ramping up of supply reduction efforts. These two efforts stood in contradiction of each other. Further, the implementation of neoliberal reforms were often to the detriment of drug war objectives given that the drops in income and reductions in public sector jobs symptomatic of neoliberal reform pushed more people into informal sectors and drug related industries because of lack of opportunities elsewhere. This is clear in the case of Bolivia, where the Bolivian government under Banzer implemented neoliberal reforms to an unprecedented degree (much to the delight of the United States and the IMF), while simultaneously struggling to control the growth of coca within its borders as more Bolivians turned to the informal sector given their incapacity to make a viable living elsewhere (Grandin, 2007: 202).

The reality of neoliberal governance is that rarely has it been implemented in its pure form, and, as David Harvey writes, is often wrought with contradictions (Harvey, 2005: 70). US interventionist efforts to stifle drug production are not anomalous if we situate them in the history of US foreign policy over the last four decades. Although neoliberal thought would stipulate that such initiatives should not be pursued as they often incur massive debts, the United States has rarely followed the doctrine that it has so enthusiastically pushed on the developing world. Dan O'Meara writes that US interventions are based on ideas of American exceptionalism. O'Meara highlights that part of the mainstream narrative in the US, as exemplified by the discourse employed by politicians and the media alike, is that as a polity, the United States is somehow superior to all others and the values which forge American identity, should be adopted globally 
(O’Meara, 2010: 38-46). O’Meara writes that this notion of American exceptionalism assumes that others are incapable of managing their own problems, and so, it is the role of the United States to step in and fix them (2010: 42). O'Meara highlights the statements of President George W. Bush in furthering his argument: "The United States must defend liberty and justice because these principles are right and true for all people everywhere" (2010: 43). Although an interventionist foreign policy position is in tension with the tenets of neoliberal doctrine, the adoption of neoliberal governance in the United States has coincided with a foreign policy position that "increasingly turns to military might to impose its rules" (O'Meara, 2010: 64).

It is easier to reconcile the push towards neoliberal reform and the move towards a more aggressive approach in the anti-drug effort, if we understand that these shifts occurred in a context in which neoconservative thinking was prominent in the United States. While neoconservative thought is in line with neoliberal thought in that it advocates individual freedom, the primacy of the (private) market and corporate power (Harvey, 2005: 82), it differs in its "overweening morality as the necessary social glue to keep the body politic secure in the face of external and internal dangers" (Harvey, 2005: 82). For neoconservatives, "unbridled individualism... generates a situation that becomes increasingly ungovernable" (Harvey, 2005: 82). And so, we can understand the anti-drug effort, as well as efforts to curtail reproductive rights and same-sex marriage, as reflective of the prominence of neoconservative thought in the United States. Harvey writes "the neoconservatives therefore emphasize militarization as an antidote to the chaos of individual interests" (Harvey, 2005: 82). This is very much evident in examining the US anti-drug effort both at home, and abroad. 
If we can understand the norms surrounding drug production and consumption as emerging prior to the onset of neoliberal governance, and we argue that these ideas became consolidated in a hegemonic world order independent of the tenets of neoliberalism, anti-drug efforts can be justified along neoliberal lines. If the idea that narcotic drug production and consumption are to be prohibited is a taken for granted, unquestionable truth (as we could argue it was for many decades), than efforts to contain the cartels in places like Colombia, Mexico and Guatemala can be reconciled with neoliberal thought. For IOs operating in Latin American in the post debt crisis context, attracting foreign direct investment (FDI) was central to achieving 'development' and economic growth. According to these IOs, violence of the scale experienced in Colombia and Mexico, and increasingly Guatemala, deters foreign investors given fears they may have about doing business in that country. Interventions in these countries were also justified by arguments that posited that the presence of drug cartels undermined democratic institutions and the government's capacity to function effectively. As 'good governance' to attract FDI became the focus of the IMF in the 1990's (essentially laying blame upon the governments of the developing world for the fact that structural adjustment programming had not delivered the desired results), we can reconcile the War on Drug effort with neoliberal governance in the region. Of course, we can also draw similarities between the two efforts, in that many have made similar arguments about the neoliberal project and the anti-drug project whereby fundamentally, they were about maintaining US hegemony in the hemisphere.

\subsection{Conclusion}


In examining the War on Drugs effort over the course of the last 40 years, what becomes clear is the prominent role that the United States has played in the construction of an international legal framework based on prohibition and the imposition of repressive military based strategies for managing the drug problem in the post-war era. We can situate the development of the drug prohibition regime in the context, which Cox describes as "Pax Americana," whereby the United States acted as the unquestioned global hegemon. As established, the drug prohibition regime gained ideological recruits, and to an extent, became hegemonic by consensus. Where opposition arose in peripheral countries, the dominant ideology was imposed by threat of economic sanction, or even in some cases, by the threat of violence. Over the course of the last five years, we have seen an emerging consensus that the tactics of the War on Drugs quite simply, failed. Given that drug production, distribution and consumption all remain to be relatively stable, in spite of the $\$ 1$ trillion dollar 'War on Drugs' effort, and the violence associated with drug trafficking continues to riddle countries like Mexico and Colombia, calls for change in the arena of drug policy are certainly warranted. This new emerging consensus will be the subject of the next chapter. 


\section{Chapter: The shifting trajectory of the international discourse on drugs}

Over the last couple of years, alternative conceptions of how to manage the problems of drug production, trafficking and consumption have emerged from both actors and institutions that we can classify as 'mainstream,' as well as actors that fall outside the margins of American ideational hegemony. This re-conceptualization is based on a widespread understanding that supply side and prohibitionist strategies have largely failed. Given that much evidence suggests that supply side strategies have failed, this discourse has come to have a degree of authority. Further, with prominent figures like Bill Clinton, Kofi Annan, Fernando Henrique Cardoso and Richard Branson advocating an end to the War on Drugs, and a movement towards an end to the global prohibition regime, a position that was once essentially inconceivable in international governance circles is increasingly making its way into the mainstream. An array of factors have coalesced to facilitate the emergence of this discourse. Of course, the fact that supply side and prohibitionist strategies have quite simply not worked is central to this reconceptualization. However, changing attitudes towards the consumption of some previously banned substances, the shift away from a neo-conservative foreign policy strategy in the United States and the turn towards leftist (and anti-American) governance in the Latin American context have all opened spaces for re-imagining how we should manage the drug problem at the local, national and international level.

This chapter will explore the new, emerging consensus on drug policy formation that stipulates that we should move away from prohibitionist, supply side strategies and towards decriminalization and a public health approach, in order to argue that we are 
seeing the emergence of a counter-hegemonic approach to drug policy. First, this chapter will begin with a review of the 2011 Report of the Global Commission on Drug Policy and the recent Organization of American States (OAS) report entitled "Scenarios for the Drug Problem in the Americas," and take them as evidence of the notion that mainstream position on this issue at the international level is beginning to shift. Then, this chapter will present statements of various prominent figures in international governance, who we can understand as 'transnational norm entrepreneurs,' to further this claim. Next, this chapter will turn to the general trends emerging out of South and Central America by examining the policy positions of UNASUR and CELAC to discuss how South and Central American countries are contributing to the formation of a strong counterhegemonic discourse in the arena of drug policy. Finally, this chapter will turn to the positions of the United Nations and the United States and the obstacles that these two prominent actors likely present to deconstructing the global prohibition regime. First, however, it is necessary to outline why the prohibitionist, supply side strategies of the decades prior have been largely deemed a failure.

\subsection{The global prohibition regime discredited}

While an estimated \$2.5 trillion USD have been poured into efforts to stifle drug production and consumption (Wood, 2012), fifty years after Nixon declared the War on Drugs, the initiative has had little if any success in realizing its objectives. Given that the prohibitionist, supply side effort has seen very marginal success, it is unsurprising that the global prohibition regime is beginning to be discredited. Interestingly, this is occurring largely in the absence of a consolidated transnational movement calling for 
change. Further, few movements calling for policy change have emerged at the national level, even in countries like Mexico and Colombia where millions of people have directly felt the fallout of prohibitionist, military based strategies.

Despite the best efforts of the United States and their allies, the global drug industry is booming. In 2011, the global trade in illicit drugs was estimated to exceed \$322 billion per year (UN General Assembly, 2011). While strides have been made over the course of the last ten years towards reducing the global agricultural outputs of coca and opium, the price of drugs on the street has remained, for the most part stagnant (Werb et al, 2013: 1). Dan Werb et al drew data from seven regional drug surveillance systems in order to paint a picture of long term, global trends in the pricing of heroin, cocaine and cannabis. The researchers adjusted the prices based on both inflation and the purity of substances. Over time and at the global level, the study found that the heroin, cocaine and cannabis purchased on the street had in fact become less expensive and increasingly pure (Werb et al, 2013: 6). The study found in the United States that "the average inflationadjusted and purity-adjusted prices of heroin, cocaine and cannabis decreased by $81 \%$, $80 \%$ and $86 \%$, respectively, between 1990 and 2007" (Werb et al, 2013: 4). Increased efforts to reduce drug production, beginning in the late 1980's, have in fact coincided with a significant drop in the street prices of drugs. This is not unexpected given the emphasis on supply reduction schemes and the fact that many estimates say that the price of coca grown in Peru, Colombia or Bolivia factors only $0.5 \%$ into the street price of cocaine (Farthing and Kohl, 2001: 37). In light of this, the only possible way to significantly affect the street price and availability of cocaine through eradication programs would be to successfully eradicate every coca crop - a feat that is nearly, 
functionally impossible in remote corners of the Andean region. Further, the number of drug users has actually increased significantly over the course of the last couple of decades (Global Commission on Drug Policy, 2011: 4), and we are seeing new global patterns of drug use emerge. While consumption was once mainly concentrated in affluent Western countries like the United States, we are seeing increased consumption in middle-income countries like Brazil, where the use of crack and cocaine has skyrocketed over the course of the past five years (Forero, 2013). Over the last 20 years we have seen shifts in terms of which drugs are being used and which people in which countries are taking them. Overall though, we have not seen significant shifts in the numbers of people consuming narcotic substances globally. In the 2013 UNODC Report, the report estimated that in 2011, between 167 and 315 million individuals had used narcotic substances (2013: 1). This represents between $2.3 \%$ and $4.5 \%$ of the global population in 2011 (UNODC, 2013: 1). In comparison, in 2000 an UNODC report entitled "Global Illicit Drug Trends 2000" estimated that between 3.3\% and 4.1\% of the global population had used narcotic substances over the course of the 1990s (2000: 116). From these statistics, we can understand that drug use has remained relatively stable over the course of the last twenty years, despite ramped-up efforts to stifle drug production, trafficking, and consumption.

Another reason for the increased calls from international actors for new approaches to drug trafficking is that illicit drug markets are consistently accompanied by violence. This is very much evident in the Latin American context - particularly in Colombia and Mexico. Under President Felipe Calderón, who during his presidency implemented one of the most militaristic approaches to managing the cartels that Mexico 
has ever seen, estimates place the number of murdered and missing related to the Drug War at 100,000 in just six years (Booth: 2012). In Colombia, in a conflict fueled by illegal drug trafficking and a punitive response to it, upwards of 220,000 people have died since 1958 (Al Jazeera, 2013). In recent years, we have also seen increasing spill over into countries on trafficking routes, like Guatemala and Honduras. Even in the American context, we see gun violence associated with drug trafficking and dealing. There is a body of literature, often employed by politicians and drug enforcement agencies, which suggests that drug users and addicts often turn to non-violent and violent crime as a symptom of their habits or to fund their addictions (Resignato, 2000: 682). Many, however, have convincingly argued that this violence is a side affect of prohibitionist policies and military based responses to the drug problem (Resignato 2000: 683). Proponents of the new emerging discourse argue that if you were to legalize or decriminalize and regulate the sale of narcotic substances, you would eliminate the raison d'être of the drug cartels, thereby reducing the violence that comes with them.

In an empirical analysis of drug related violent crime in the United States, Andrew Resignato found that structural explanations, including drug prohibition and increased drug enforcement, for drug related crime were much more compelling than explanations that posited crime was a symptom of the psychological affects of drug consumption or economic motivations whereby drug users need to engage in criminal activity to fund their drug habits (2000: 688). Resignato looked at arrest records in 24 American cities. Through empirical analysis, Resignato found that "when there is a higher allocation of police resources to drug crime relative to total police resources allocated to crime, there is a higher murder rate and violent crime rate" (2000: 687). 
While Resignato did find a small correlation between narcotic drug abuse and violent crime, the empirical relationship was weak (2000: 687).

Nowhere is the violence related with the drug trade more evident today than in Northern Mexico where cartels have infiltrated police forces and become more powerful than the military forces that have been sent in to stifle their hold on the region (Freeman, 2006: 2). Given its close proximity to the United States, the conflict in the region has been fueled by a black market in weapons, easily and often legally purchased in the United States and then smuggled across the border (Freeman, 2006: 3). The presence of the cartels rests on the presence of a global prohibition regime. In a report for the Washington Office on Latin America entitled "State of Siege: Drug Related Violence and Corruption in Mexico," Laurie Freeman writes,

Drug-related violence in Mexico is rooted in and inseparable from U.S. policy... The prohibition of drugs fuels violence, plain and simple. Similar violence does not exist in markets for legal goods like cigarettes or alcohol. Clear rules and regulations are in place for buying and selling those goods, and any disputes can be handled by the legal system. (Freeman, 206: 16)

Further, the large increase in military presence in the Northern region that began under President Felipe Calderón has actually worked to exacerbate the levels of violence (Freeman, 2006: 8). The OAS report compares deaths related to drug use in Brazil with deaths related to drug violence in Mexico to argue that "the number of deaths caused by drug use is far less than those caused by related crimes" (OAS, 2013: 83). The statistics are just as telling if examine drug use related deaths in the United States. While the number of annual deaths related to narcotic drug abuse in the United States is on the rise, they mirror the fatalities associated with the drug war in Northern Mexico. If we remove prescription drug abuse in the United States from the picture and look only at drug abuse 
of 'illicit' substances that are crossing the border from Mexico into the United States, like cocaine, heroin and marijuana, we find that the deaths associated with the violence that stem from the increased military enforcement of prohibition in Mexico are similar to the number of deaths associated with illicit drug overdose in the United States. While 38, 329 people in the United States died of drug related deaths in $2010,60 \%$ of these deaths were a result of prescription drug abuse (CDC, 2013). Accordingly, we can infer that 15, 331 people died in the United States as a result of the overdose of all illicit substances. Further, that same year, as in many years, there were zero recorded deaths related to the consumption of cannabis. In that same year, 15, 273 people died as a result of drug related violence in Mexico (Stevenson, 2011). The policies designed to protect individuals from the detrimental affects of ingesting harmful substances, have given rise to an illicit market and repressive policies that have, in turn, killed many more people than prohibition has likely protected. Given that the population of Mexico is around a third of that of the United States, we can come to understand that the costs in terms of human lives of prohibition likely outweigh the supposed benefits whereby less people die of drug overdose.

\subsection{The emergence of a new discourse at the international level}

\section{i) The Report of the Global Commission on Drugs}

Over the last decade, we have seen the emergence of specific non-governmental organizations, policy think tanks and advocacy groups centered on deconstructing the global prohibition regime and conceptualizing alternate ways of managing the issue of narcotic drugs. The emergence of these actors and platforms indicate the emergence of a 
strong counter-hegemonic discourse emanating from a variety of sites. Two of the most prominent are The Drug Policy Alliance, based in New York City and The Global Commission on Drug Policy, whose efforts are more international in scope. The Global Commission on Drug Policy is of particular interest because of its high profile affiliations with prominent figures in international politics. Amongst the commissioners for the 2011 "Report of the Global Commission on Drug Policy" are such powerful figures as Cesar Gaviria, Fernando Cardoso, George P. Shultz, Kofi Annan, Louise Arbour, Paul Volcker, Richard Branson and Ruth Dreifus. These are individuals that we can understand as being members of the transnational elite, as outlined by Robinson, and as responsible for the maintenance and propagation of global hegemony. The report is significant in that it is explicit in its assertion that the War on Drugs has failed and in its calls for "urgently needed" reforms at the international level (Global Commission on Drug Policy, 2011: 2). While the report's recommendations are perhaps difficult to interpret as groundbreaking given the extent to which the War on Drugs effort has clearly failed, it is unprecedented that so many prominent actors, who we could generally classify as members of the transnational elite and agents of ideational hegemony, have their names affiliated with such a report - especially when the US government shows little movement on deconstructing the global prohibition regime.

The report offers four core principles that it believes should guide the formulation of international and national drug policies and then goes on to issue 11 recommendations. The four core principles can be paraphrased as follows:

1. Drug policy formulation should be based on empirical and scientific evidence and measures of success should rest on the reduction of harm to the health, security and welfare of members of society. 
2. Drug policy formulation should be based on principles of public health and human rights. Efforts should be made to end the stigmatization and marginalization of "people who use certain drugs" and those involved in the lower end of drug production and trade.

3. While drug policy formulation and implementation should be a "global shared responsibility," it needs to take into account contextual specificities and "political, social and cultural realities."

4. Drug policies must be implemented in a "comprehensive manner, involving families, schools, public health specialists, development practitioners and civil society leaders, in partnership with law enforcement agencies and other relevant governmental bodies." (2011: 5-9)

After outlining the core principles of the Global Commission on Drugs, the report goes on to issue its recommendations. Amongst the most ground-breaking recommendations is recommendation three that calls upon governments to experiment with the legalization and regulation of not only marijuana, but other currently banned substances (2011: 11). We can understand the suggestion to legalize certain currently banned substances as counter-hegemonic in that it stands in direct tension with the 1961 Single Convention on Narcotic drugs and makes strides towards the de-securitization of drugs. Also of significance is recommendation five that calls upon governments and the international community to re-conceptualize how we think about, talk about and treat drug users, addicts and low level producers (2011: 13). This re-conceptualization of actors involved in the drug issue is very much emblematic of a paradigm shift, and can be understood as counter-hegemonic in that they stand in that these ideas stand in direct tension to the ideas propagated and policy implemented in the past. While many governments (and especially the US government as evidenced by the unprecedented number of Americans in jail for low-level drug crimes) have treated both addicts and low-level dealers as criminals, increasingly we are seeing an acknowledgement of the socio-economic conditions that lead individuals to drug dealing and a re-conceptualization of drug 
addiction as a disease rather than a matter of free will. The Drug Commission's report exemplifies this re-construction of these archetypal actors in the war on drugs narrative. Although it makes brief reference to the socio-economic conditions that lead people to drug addiction, production, trafficking or dealing on three occasions, the report is not radical in that it does not address the structural conditions, like poverty and lack of alternate economic opportunity, that underlie the drug problem. In painting low level actors in the drug trade as drug addicts often working to fuel their own habit, it in fact deflects attention from the fact that this industry is one thriving in a context of the most prolific levels of inequality the world has ever seen under neoliberal governance and high levels of poverty, especially in producer and trafficking countries. In this sense, while the report advocates experimentation in drug policy formulation and is openly critical of the global prohibition regime and the actors and institutions who uphold it, it does not necessarily disrupt the dominant, neoliberal ideological orthodoxy of the day. As such, we cannot understand it as counter-hegemonic according to the Gramscian definition. While the report of the Global Commission on Drugs is perhaps not radical in its proposals given the evidence that exists to discredit prohibitionist, supply side strategies in reducing drug consumption and in that it fails to acknowledge the structural roots of the drug problem, it is significant in that its recommendations are in direct tension with the tenets of the global prohibition regime and in that so many prominent figures (who we can understand as members of the transnational elite) in international governance have their names attached to the report. 
ii) The report of the Organization of American States: "The Drug Problem in the Americas"

Also of interest is the 2013 publication of the Organization of American States (OAS), entitled "The Drug Problem in the Americas." The OAS was established in 1948 as a regional organization of 35 member states, in order to "achieve an order of peace and justice, to promote their solidarity, to strengthen their collaboration, and to defend their sovereignty, their territorial integrity, and their independence" (The OAS, 1967: 4). American influence in the OAS mirrors the preeminent position of the United States in the hemisphere - many Latin American leaders have pointed to the OAS as an agent of American ideational hegemony in the region. During the Cold War period, many understood the OAS as "the ultimate expression of the Monroe Doctrine and the US assertion of hegemony in the Western Hemisphere" (Miller, 2009: 7). The organization was vital to US hemispheric interests in terms of stemming the communist threat in the Cold War context (Miller, 2009: 7). The dominance of the US in the institution during this period can be exemplified by the US led initiative to remove Cuba from the organization after the Cuban revolution and the turn to communist governance in Cuba. Despite the fact that most countries in the Latin American region maintained diplomatic and economic relations with Cuba in the aftermath of the Cuban revolution, in 1962, under significant pressure from the US government, Cuba was suspended from the OAS with the vote passing 14-1 with six abstentions (Miller, 2009: 9). While the organization acts as a platform for the discussion of issues facing the hemisphere and brings into its fold governments that differ substantially in terms of ideology, few of its reports or publications can be considered radical. Given the prominent position of the United States 
within the hemisphere and the OAS, and the fact that the American government has shown little desire to make significant changes to the global prohibition regime, the conclusions made by 2013 report are all the more surprising. With the end of the Cold War however, the importance of the OAS as a tool for achieving US objectives has decreased, opening spaces for policy innovation (Isacson, 2013). This is further compounded by the move away from an invasive foreign policy strategy pertaining to Latin America, under the Obama administration. In the past decade, we have seen not only the readmission of Cuba into the OAS but pronounced tensions between member nations (Isacson, 2012). This being said however, given the creation of organizations like CELAC and UNASUR that bring together governments that are less ideologically diverse, we could expect their publications to be more in tune with the position in the Latin American region, while those of the OAS still try to maintain some balance between the differing positions of member states who sit at different spots along the ideological spectrum.

In the opening statement of the report, Secretary General of the OAS, José Miguel Insulza writes that the drug problem is "one of the most important challenges facing the hemisphere" and that "the current approach... has not been successful and is not working well enough" (2013: 8). The report itself includes an analysis of the problems of drug cultivation, production, trafficking and consumption in the region and then offers four scenarios to guide future policy formulation. The underlying notions, upon which the report is premised, differ substantially from the old orthodoxy. While the UN conventions concerning the control of narcotic substances can be described as prescribing a 'one size fits all' strategy in which each country was to make production and consumption illegal 
and work to stem drug supply at the source, the OAS report is explicit in its recognition that what is needed are context specific approaches that experiment with a range of policy options, including, in some cases, deregulation and even legalization (2013). While the old orthodoxy constructed drug producers, traffickers and users as deviant and managed them through the criminal justice system, the OAS report recognizes the need for a public health approach (2013: 5). In this sense, the OAS report works to de- and re-construct notions surrounding various actors involved in the drug problem. The old discourse constructed those involved in drug trade or drug use as deviant (although there were varying degrees of deviancy). The emerging discourse is more nuanced in its construction of drug producers, traffickers and users. The category of victim, which was once reserved for youth approached on American inner city playgrounds by the neighborhood drug dealer and innocent women and children caught in the crossfire, has been expanded to include low level producers and sellers who fall into the drug trade based on lack of other opportunities, and addicts who are now understood as having an illness (2013: 25). This reconstruction of actors also recognizes the human rights abuses that have been committed in the name of stifling drug production and consumption (2013: 25). The report places emphasis on structural factors (to a more significant extent than the Report of the Global Commission on Drugs) like inequality, poverty and lack of alternate opportunities, which have allowed the drug problem to flourish in the Americas and states that "structural problems need to be addressed with structural solutions" (2013: 25). Further, given this reconceptualization of actors involved and recognition of the structural factors at play that facilitated the drug problem, the report understands the levels of incarceration associated with the drug war as being problematic and argues for 
an end to strategies that rely heavily upon the criminal justice system (2013: 89). Finally, in recognizing that supply side strategies have done little to stifle the drug problem, the report points to demand as being a significant part of the problem, and advocates for the implementation of programs to curb demand (2013: 75).

In exploring scenarios for the future trajectory of drug policy in the Americas, the OAS report displays clear biases towards "scenarios" that entail a major obstruction of the current approach to managing the drug problem. The report is explicit at the outset that part of its intent is to try and think about ways of stemming the violence associated with the drug trade in the Americas (2013: 8). As such, we can assume the report favours scenarios in which the predicted outcome is less violence. Interestingly, in the scenario that suggests the implementation of new legislative frameworks, including the legalization of some substances like marijuana, and the scenario that understands the root of the problem as lying in structural factors like poverty and inequality, the predicted outcome is less violence. The simple fact that these propositions are favoured in such a report, or even included, is exemplary of a paradigmatic shift.

While the OAS report arrives at quite similar conclusions to the "Report of the Global Commission on Drugs," it digs deeper in re-conceptualizing actors involved in the drug trade and recognizing the structural conditions that have given rise to this problem. In this sense, we can understand it as being counter-hegemonic, as it stands in tension with the old policies prescribed. The report works to disrupt the dominant hegemony surrounding the management of illicit drugs. Further, the recognition that the problem is symptomatic of the high levels of inequality and poverty experienced by most Latin American countries, works to subtly disrupt the neoliberal consensus. All of this being 
said, the analytical report fails to assess the extent to which forced eradication programs, including aerial spraying, have been disastrous for millions of individuals who are involved in low-level (and low income) drug trade operations. Further, the report does not make firm links between the current policies and the alarming levels of violence associated with the drug trade in the Central American region. While the report is firm in its calls for a new approach, it is not overly critical of the approach to which we can credit the dire situation that many governments find themselves in today.

\section{iii) Statements of prominent actors in global politics}

Alongside these new reports, we have seen prominent figures in international politics (that we can understand as members of the transnational elite) issue very overt criticism of the old approach to drug policy in their calls for change - even individuals who were once complicit in the maintenance of the global prohibition regime and advocated for and implemented supply reduction strategies. Amongst others, two very clear examples of this are the statements issued by both former American President Bill Clinton, whose administration was active in employing supply side strategies in South America and former Secretary General of the United Nations, Kofi Annan. "Breaking the Taboo" is a 2013 documentary that was produced in affiliation with the Global Commission on Drugs. In the documentary, Clinton reflects upon the failures of his administration's Plan Colombia, when he says "well obviously if the expected results was that we would eliminate drug use in America, and we would eliminate the narcotraffickers, it hasn't worked" (2013). While acknowledging that drug use is obviously detrimental to ones health in saying that being drug free is "the key to freedom" and "the 
key to your future," Clinton makes the overt assertion that current policies are not working. Clinton says,

We could have fighting and killing over cigarettes if we made it a felony to sell a cigarette. So we legalized them. If all you do is try to find a police or military solution to the problem, a lot of people die and it doesn't solve the problem. (2013)

Clinton goes on to advocate for harm reduction programs, employing his brother's struggles with addiction in such a way that it humanizes the drug user (2013). Given the moralistic undertones of Clinton's statements, we can understand him as a moral entrepreneur, as outlined by Nadelmann. Although, aside from this documentary, Clinton has remained quiet on the issue of drug regulation his statements here are important, given that his administration once implemented supply side strategies and the prominent role that he continues to play in international politics. In statements made by Clinton, the moral imperative becomes ending the war on drugs, in contrast to statements made during his presidency where the moral imperative was reducing drug consumption in the United States through any means possible. Clinton, however, does not address the structural roots of the problem in his statements, and so his statements can be reconciled with public opinion in the United States and do little to disrupt the dominant neoliberal ideological order of the day. In this sense, it is difficult to understand his statements as counter-hegemonic. However, given that his statements run parallel to the emerging counter-hegemonic consensus, it can be argued that his testimony contributes to the authority of the statements made and policies implemented that we can classify as counter-hegemonic. 
Former UN Secretary General Kofi Annan has been much more outspoken than Clinton in his calls for an end to the Drug War. In an opinion piece written by Annan and former President of Brazil, Fernando Henrique Cardoso and published by CNN, the two write,

Each year, hundreds of thousands of people around the world die from preventable drug-related disease and violence. Millions of users are arrested and thrown in jail. Globally, communities are blighted by drug-related crime. Citizens see huge amounts of their taxes spent on harsh policies that are not working. But despite this clear evidence of failure, there is a damaging reluctance worldwide to consider a fresh approach. (2013)

Annan's writing, statements and proposals are in direct tension with the policy prescriptions that the United Nations continues to prescribe. Annan echoed his thoughts in his CNN op-ed, when he sat on a panel at the World Economic Forum in Davos, Switzerland concerning the "drug dilemma" in late January of 2014. In his opening statement, Annan says,

I believe that drugs have destroyed many people. But wrong governmental policies have destroyed many more, and we need to really look at the policy and ask ourselves simply, sincerely and honestly, is this policy working, what are the effects of this policy, and if it is not working, do we have the courage to change it? At least there is a need for serious public debate on this issue... the question is are we ready to make an honest review?

He goes on to say,

If we admit that drug policy, and the repressive laws on drugs have failed, and it ends up throwing so many people in jail, I don't know if the governor (referring to fellow panel member, Rick Perry), can confirm this but I am told that the US for example, the government spends more money on prisons than on education.

Obviously there is something wrong when one is confronted with this situation. Is this a situation that can be defended? Isn't this a situation that is crying out for review? Different policies? I will leave it there. 
Annan's statements are often underpinned by moral considerations. In this sense, Annan is advocating for the transformation of international norms based on principles of morality, in a similar vein to those who advocated for prohibition in the first place. Annan's statements are especially significant in that he used to be the Secretary General of the United Nations. While Kofi Annan is from Ghana, which is a peripheral country, we can understand Kofi Annan as being a member of the transnational elite class that works to maintain international ideational hegemony. Robert Cox understands international organizations, like the UN, as co-opters of elites from the peripheral countries and absorbers of counter-hegemonic ideas. Further, Robinson posits that members of the transnational elite class share more in common with each other than with the peasant class in their home country and work to maintain the structures of international ideational hegemony. Organizational arms of the UN of and lead dignitaries at the UN continue to advocate for the prohibition of drugs, the maintenance of the global prohibition regime and the abidance of the principles of the 1961 and 1988 conventions. As previously mentioned, much of this new emerging discourse is not in tension with the dominant neoliberal orthodoxy of the day. Arguments for the end of prohibition also center on principles of individual freedom and self-determination. This is very much evident in a recent op-ed of ex-Mexican president Vicente Fox. Fox calls for the legalization of not just marijuana, but all drugs, saying that it is simply "the right thing to do" (2014). His argument is justified in terms of liberal notions of freedom:

Each person should be free to decide what's best for himself or herself. We are all created equal and free. If we are created in such freedom, then we must be given the very freedom to decide our own behavior and to act responsibly. (2014) 
Fox, who over the course of his presidency was quite friendly with his neighbours to the North, is openly critical of the American approach to drug control, and is explicit in his assertion that the situation in the North of Mexico is a direct result of American policy decisions. This is also of note because his statements, although not explicitly, are critical of the policy direction taken by his own party under President Calderón. While he advocates an end to prohibition on the grounds of individual freedom, interestingly, he does not understand those involved in the drug trade in Northern Mexico as participating in it based on their own free will (2014). This falls outside the dominant discourse on drug traffickers that labels them criminals and as making bad decisions of their own free will. For Fox, "these people were not born criminals" and they fall "victim" to the drug trafficking industry because of a lack of other economic incentives or opportunities and "flawed public policy" (2014). In Fox's piece, this is evident when he employs the words of Abraham Lincoln, who is widely revered by the American public as being a figure of moral authority, in his call for policy change. In his call for change, Fox writes,

The time has come for the governments of our countries, and for governments worldwide, to act and to govern as was envisioned by the great president Abraham Lincoln" "That this nation, under God, shall have a new birth of freedom - and that government of the people, by the people, for the people, shall not perish from the earth." (2014)

For Fox, legalizing drugs and deconstructing the global prohibition regime becomes a moral imperative.

The ideological strength of the discourse being propagated by organizations like the Global Commission for Drug Policy and the OAS and individuals like Clinton, Annan and Fox, lies in the fact that it is emanating from members of the transnational elite who have a degree of authority and respect in the international system. Interestingly, shifts in 
this discourse have emerged in the absence of a strong transnational movement for change on this issue, or even consolidated national movements calling for policy change (except for perhaps in Bolivia).

\subsection{The emergence of a new discourse in South and Central America}

In the Latin American region, ideas on how to manage the drug problem remain fragmented and strategies vary. While drug consumption is beginning to rise, historically, the countries of South and Central America have not, until recently, faced the levels of consumption that Western nations have. As such, in the Latin American context the drug problem has been one of production and trafficking. As it is not within the scope of this project to explore the individual, national strategies employed by each Latin American country, the positions UNASUR and CELAC will be taken as indicative of wider trends emerging in the region. Riggirozzi and Tussie understand the formation of organizations like UNASUR and CELAC as indicative of the emergence of post-hegemonic regionalism in Latin America and argue that the formation of strong regional blocs opens spaces for counter-hegemonic policy innovations (2011: 2).

The proposals made by both groups on how to manage the issue of the drug problem mirror the tenets of the new emerging discourse. In their publications, CELAC refers to the issue as the "problema mundial de las drogas," indicating that they understand the drug problem as one that doesn't emanate solely from, for example, the coca plantations of Colombia, Peru or Bolivia. As such, responsibility for the global drug problem is one that is shared by all countries. In the publications of both UNASUR and

\footnotetext{
${ }^{6}$ My translation: Global drug problem
} 
CELAC, much emphasis is placed on arriving at a cohesive strategy that tackles both supply and demand, and involves a higher level of cooperation between governments in the region. In several of the publications, we see significant emphasis placed on the issue of demand in the developed world. This is made very clear in CELAC's Comunicado Especial Sobre Drogas ${ }^{7}$ :

La efectiva reducción de la demanda en los países desarrollados es condición esencial para el éxito en la lucha contra el tráfico ilícito de drogas y sus delitos conexos; $;^{8}(2011: 1)$

This is exemplary of the regional position that stipulates that responsibility for the issue needs to be shared, and cannot rest solely on the shoulders of the governments of producing nations as it has in the past. Further, both organizations call upon the United States to take on a more active role in confronting the issue of arms smuggling given that many of the arms being smuggled into the hands of those engaged in drug related violence are coming out the United States as smugglers are able to take advantage of lax gun regulation on the Southern U.S. border (CELAC, 2011: 2)(UNASUR, 2013: 4).

Overall, it seems that there is wide agreement that strategies for managing the drug problem need to involve the cooperation of governments in the region. UNASUR has set up institutional mechanisms to facilitate this. In 2011, UNASUR created the Observatoria Suramericano sobre el Problema Mundial de las Drogas. ${ }^{9}$ The organization acts as a mechanism for information sharing, both about policy experiences and data concerning the fight against drugs in the region (UNASUR, 2011).

\footnotetext{
${ }^{7}$ My translation: Special Communication About Drugs

${ }^{8}$ My translation: The effective reduction of demand in developed countries is an essential condition for success in the fight against illicit drug trafficking and its related offenses.

${ }^{9}$ My translation: South American Observatory for the Global Drug Problem
} 
Similar to the reports of the Global Commission and the OAS, UNASUR advocates moving away from strategies that rely heavily on law enforcement and towards a public health approach. The organization goes so far as to say that discussing the drug problem as a "fight against drugs," is problematic in that it detracts from the need for a public health approach:

... Bajo la logica de que la expression lucha contra el narcotráfico implica "distorsionar y restar importancia al enfoque de salud pública y por tanto se aborda el prolema en forma guerrista, sin motivar la organizacion social y comunitaria”... ${ }^{10}$ (2013: 2)

This is further reflected in publications by CELAC that call on governments to strengthen the resources available for the treatment of individuals with drug dependencies and increase resources directed towards the prevention of narcotic drug use (2011:3).

The position of CELAC and UNASUR on the issue of coca chewing, unsurprisingly, differs substantially from that of the wider international community. In 2011, CELAC issued a special communication outlining their position on the indigenous practice of coca chewing in Bolivia and Peru. The timing is significant, in that it is around the same time that Bolivia withdrew from the 1961 Single Convention on Narcotic Substances because of the refusal of member nations to remove the coca leaf from the list of banned substances. The CELAC communication was clear in its support for the legalization of coca chewing:

\footnotetext{
${ }^{10}$ My translation: The logic of the fight against drugs, the expression distorts and downplays the importance of a public health approach and addresses the problem through military means, without social and community motivations
} 
Reafirman el compromiso de apoyar las prácticas culturales y ancestrales de los pueblos originarios, en el marco del respeto de los Derechos Humanos y los Derechos Fundamentales de los Pueblos Indígenas. ${ }^{11}$

Asimismo, reconocen que el uso tradicional del masticado (akulliku) de la hoja de coca es una manifestación cultural ancestral de los pueblos de Bolivia y Perú, que debe ser respetada por la comunidad internacional. ${ }^{12}$

These statements advocate the legalization of coca chewing based on moral considerations of human rights and respecting indigenous traditions. Latin American countries have also generally supported Uruguay's decision to legalize marijuana as well. UNASUR issued a statement expressing its approval for Uruguay's recent policy move (2013). Further, we are seeing an increasing number of countries in the region move towards the decriminalization of marijuana and even talk of its legalization.

What is emerging out of Latin America is a discourse and an approach to drug policy that is significantly more radical than that emerging on the international stage. In Latin America, the drug problem is understood as one that stems not only from supply but also from demand, which runs counter to the hegemonic discourse. Further, calls for the international legalization of coca cultivation and chewing, premised on the grounds of indigenous rights, and support for marijuana legalization are in tension with the position the UN continues to maintain. We can also understand the position taken by the countries that make up UNASUR and CELAC as counter-hegemonic in that it transcends economic

\footnotetext{
${ }^{11}$ My translation: Reaffirming our commitment to support the cultural and ancestrial practices of the first/original people, in the framework of respecting Human Rights and the Fundamental Rights of Indigenous People

${ }^{12}$ My translation: Also, recognizing that the traditional use of coca chewing is a cultural and ancestrial tradition of the people of Bolivia and Peru, that must be respected by the international community
} 
considerations. In the case of Bolivia for example, implementing an approach to managing the drug problem that is in tension with the orthodox approach has meant Bolivia has forfeited large sums of financial aid from the US. Given the region's experience with drug prohibition, the emergence of a counter-hegemonic approach is unsurprising. Counter-hegemonic developments emerging out of Bolivia and Guatemala will be discussed in more detail in the subsequent chapters.

\subsection{The position of the US and the UN: Maintaining the global prohibition regime}

While there have been strides made in the direction of policy reform, it is important to note that the positions of the US and the UN continue to present obstacles to the deconstruction of the global prohibition regime. To date, no official UN agency or publication has called for changes to either of the conventions concerning the control of banned substances or have advocated an end to the prohibition of certain banned substances, like marijuana. For example, when the Uruguayan congress voted to legalize the sale and consumption of marijuana, becoming the first country in the world to do so, the International Narcotics Control Board (INCB), which is the control organ for the implementation of the UN drug conventions, issued a press release that explicitly condemned Uruguay's move. The press release refers to the statements of the INCB's president Raymond Yans:

(I am) surprised that a legislative body that has endorsed an international law and agreements, and a Government that is an active partner in international cooperation and in the maintenance of the international rule of law, knowingly decided to break the universally agreed and internationally endorsed legal provisions of the treaty...the main aim of the 1961 Single Convention is to protect the health and welfare of humankind. Cannabis is controlled under the 1961 Convention, which requires States Parties to limit its use to medical and scientific purposes, due to its dependence-producing potential. (2013) 
Yans' issued similar criticism of recent steps to legalize and regulate the sale and consumption of marijuana in Washington State and Colorado, telling a reporter in the fall of 2013,

The position of INCB is very clear. We have no choice but to condemn the situation in those two American states... The fact that those two American states, by referendum, decided to legalize one of those substances (in reference to the substances listed in the 1961 convention)... makes it fully necessary for us to engage in diplomatic relations with the American government so that they take measures to stop this nonsense.

Yans' statements demonstrate the tensions that exist between policy decisions at the national and sub-national levels, and the position of $\mathrm{UN}$ organizations that continue to favor prohibition over legalization and regulation. Much of the preoccupation with drug trafficking still centers on links to terrorism and the threat that drug trafficking poses to democratic governance. The 'drugs as threat' discourse is still very much prevalent in the publications of various $\mathrm{UN}$ bodies. This being said, there is recognition that harm reduction programs are necessary when drug consumption remains so pervasive.

While President Obama was critical of the War on Drugs effort while he was still a Senator (Breaking the Taboo, 2013), since his election, domestically little has changed in terms of shifting the balance of funding away from efforts in the criminal justice sector and towards public health initiatives. The Obama administration has stated that it favours a public health approach over a criminal justice approach and has made moves to stem the unprecedented incarceration rates associated with the drug problem (Thompson, 2013). This being said, Christie Thompson writes,

Overall, the government spends roughly the same proportion of the drug policy budget on law enforcement now as was spent during Bush's final years in office. In Obama's 2014 budget proposal, 38 percent is allocated for domestic drug law 
enforcement, while another 20 percent would be spent to crack down on drugs along U.S. borders and abroad. (2013)

Over the course of his presidency, we have seen slight shifts in the administration's approach to marijuana consumption (Friedersdorf, 2014). While President Obama has said that recreational marijuana use should not be a priority of law enforcement agencies and agents in the fight against drugs in the United States (2014) and has to a limited extent condoned the legalization of marijuana in Colorado and Washington (2014), he has not called for legalization nation wide. Moreover, Obama has stated that he does not see the legalization of marijuana as the answer to the drug problem (2104). Where his statements differ substantially from those of past sitting Presidents is in his acknowledgement of the racial dynamics at play in regulating the drug problem through the criminal justice system (2014). And so, while we have seen shifts under Obama's presidency in the way the drug problem is managed, these shifts have not led to substantial change in policies at the federal level. ${ }^{13}$

This is evident if one looks at the continued activities of the US Drug Enforcement Administration (DEA). According to their website, the USDEA continues to support coca eradication programs in Peru and Colombia (2014). The agency has an annual budget of $\$ 3$ billion per year and continues to maintain 86 foreign offices in 67 countries (2014). 29 of these offices are in the Latin American region. Further, while the presidency has changed hands from Bush to Obama, many of the individuals who populate the halls of the DEA are holdovers from the Bush, Clinton, Bush Sr. and even

\footnotetext{
${ }^{13}$ Although, we have seen significant changes at the level of the state as exemplified by recent referendums to legalize the cultivation, sale and possession of marijuana in Washington State and Colorado in 2012.
} 
Reagan administrations. This can be said of Michele Leonhart, who occupies the top position at the DEA, and Thomas M. Harrigan, who is the deputy minister of the DEA. Harrigan began his career at the DEA as a special agent in 1987, when Reagan was in the White House (2014).

What remains unclear at this point, as norms and perceptions surrounding drug consumption begins to shift within the United States and worldwide, is whether the organs of the UN will follow suit. Given the clout that the United States has within global governing bodies like the UN, it is not difficult to argue that we can expect shifts in thinking. At the same time however, the legalization of marijuana remains low on the American federal agenda, public opinion in the United States on the issue of drug regulation is fragmented and Obama and other top officials have come out to say that they are not in favour of the legalization of marijuana or any other substance. As such it is unlikely we will see American advocacy for change on this issue at the UN. Conversely, when Bolivia was issued a special dispensation at the UN in 2011 that deemed coca chewing a legal practice within Bolivia's borders, the United States was one of 15 countries to vote against its ratification (UN). Further, given the prominent position that Russia plays at the UN, and that attitudes towards drug use and consumption are markedly more conservative than in the American context (Holt, 2010: 13-14), it is unlikely that we will see major reform to either the 1961 or 1988 conventions. With the UN General Assembly Special Session on Drugs scheduled for 2016 however, it will be interesting to see what emerges in terms of deconstructing the global prohibition regime, given the tensions that exist amongst member countries and the onslaught of a variety of 
new policy mechanisms in countries like Uruguay and states like Washington and Colorado.

\subsection{Conclusion}

Cox, Robinson and to a certain extent the liberal theorists concerned with international norm diffusion, understand international organizations as facilitators of hegemonic world order, products of hegemony themselves and absorbers of counter hegemonic ideas. While we have seen little movement from the United Nations on the deconstruction of the global prohibition regime, we can understand the OAS as an organization in the same category as the UN, given the prominent role that the United States has played historically in that organization. This makes the recent OAS report all the more unprecedented, in that it is emerging from an institution that has historically acted as a facilitator of a hegemonic world order. The softening of rhetoric under the Obama administration too, signifies cracks in the authority of the global prohibition regime, given the preeminent role that the American government plays in all international institutions. These calls for substantive policy change, the move away from militarizing the problem and towards a public health approach and the recognition that the problem is on that has arisen from the inequitable global distribution of wealth signify the emergence of a strong counter-hegemonic discourse. Although we have seen significant shifts in the way that the drug problem is talked about and thought about, substantive global shifts in policy formulation are yet to occur. Kofi Annan has, on several occasions, made this claim in his call for change. Annan alleges that a widespread acknowledgement that current policies are failing has emerged, but that governments have been slow to act 
(2014). With the exception of Colorado, Washington State and Uruguay, who have each moved towards the legalization of marijuana, the implementation of harm reduction programs in Canada and several European countries and the implementation of social control in Bolivia to reduce coca production, for the most part, at the level of the nation state, drug policy looks much the same as it did fifteen years ago. The United States continues to spend more money on prisons than it does on schools (Annan, 2014) while Mexico continues to deploy armed, military forces ${ }^{14}$ to its Northern region in an effort to contain the cartels. As drug related violence begins to plague more and more countries in not only the Central American region, but also in certain West African countries that have become new trafficking hubs, we are seeing more and more world leaders and former world leaders come forward in calls for change. It will be interesting to see what emerges from the upcoming UN General Assembly Special Session on Drugs, scheduled for 2016, and whether rhetoric surrounding the need for change will amount to substantive change and the deconstruction of the global prohibition regime. The subsequent chapters will explore in more detail the experiences of Bolivia and Guatemala - two countries whose experiences in the drug war differ significantly. The two cases will be explored to demonstrate how changes in rhetoric and policy are occurring across ideological lines.

\footnotetext{
${ }^{14}$ Although, with the election of Peña Nieto, reliance on the military for containing the cartels has subsided somewhat.
} 


\section{Chapter: Case study - Bolivia}

The Plurinational State of Bolivia provides a very interesting example of resistance to the dominant hegemony surrounding drug policy since the election of President Evo Morales in 2006. The policy direction taken by the Bolivian government under Morales and their international advocacy efforts have worked to discredit the dominant, orthodox discourse and have contributed to the construction of new norms related to drug policy. Bolivia has historically been, and remains to be amongst the poorest countries in the South American region. The predominantly indigenous country (62\% of Bolivians speak one of the indigenous languages) has faced decades of weak governance and foreign intervention (Postero, 2007: 1). The country's economy has historically been dependent upon agricultural production and mining. Coca cultivation for cocaine production has, since the late 1970s comprised a significant part of the Bolivian economy. The coca leaf, from which cocaine is derived, is primarily grown in the Andean countries of Colombia, Peru and Bolivia. After Colombia and Peru, Bolivia is the third largest producer of the coca leaf worldwide. As of 2011, 18\% of global coca cultivation occurs in Boliva (OAS, 2013: 29). Coca growth in Bolivia happens in two regions: the Yungas region north of La Paz and the Chapare region north of Cochabamba. Whereas Peru and Bolivia produce primarily coca leaves, refined cocaine is primarily exported out of Colombia in the Andean region. This being said, patterns have been changing, and given increasing demand in countries like Brazil and Argentina, countries close in geographical proximity to Bolivia, increasingly cocaine paste is exported from Bolivia (Republica de Bolivia, 2007: 33). Cultivating coca was and remains lucrative when compared with other agricultural outputs, since both regions are well suited to its growth 
and there is steady demand for coca given a global demand for cocaine. Further, coca chewing holds a very significant place in indigenous Bolivian culture and ritual. The United States Drug Enforcement Agency (USDEA) first entered the Chapare region of Bolivia in 1983 (Draper et al, 2009: 189). The region came to encompass a struggle between cocaleros (coca growers), trying to make a living in a context characterised by staunch neoliberal governance, and the forced eradication of coca plantations undertaken by both Bolivian military forces and USDEA operatives.

It is out of this tumultuous context that Evo Morales' Movimiento al Socialismo (MAS) emerged and eventually took power in 2006. The roots of the MAS are found in a coca growers union formed in the Chapare region in response to forced eradication and the host of human rights abuses that accompanied the effort (Farthing and Kohl, 2010: 197). Morales and the MAS have pursued a markedly different strategy to coca containment than governments that preceded them. In recognising the need to reduce coca production because of its implications for global cocaine production and consumption, but also being aware of the economic and cultural implications that complete eradication has, the MAS's strategy has been premised on the slogan 'coca sí,

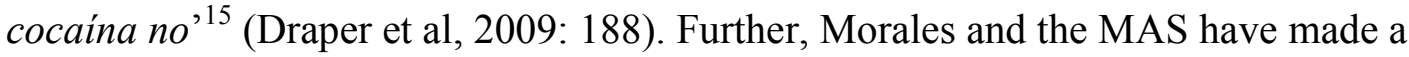
concerted effort to challenge dominant conceptions of coca and its eradication in international governing bodies. On both fronts, the Morales government has made significant strides towards its objectives. This chapter will first explore Bolivia's experience with coca eradication before turning to the strategies of the Morales government, to argue that Bolivia has taken a counter hegemonic approach to the

${ }^{15}$ My translation: Coca yes, cocaine no 
management of the drug problem, which has in turn lent legitimacy to the emerging construction of a new international hegemony in drug policy formulation.

\subsection{Bolivia and coca eradication}

In Bolivia, the coca plant embodies a variety of different meanings and has been the subject of much controversy over the past five decades. Chewed by the Quechua and Aymara peoples, who together compose nearly $40 \%$ of the Bolivian population, the coca leaf holds an important place in religious ritual and ceremony. Stolberg describes it as "a cultural marker" for the Aymara and Quechua people (Stolberg, 2011: 132). The leaf's affects are comparable to that of coffee or aspirin, and accordingly, in the Andean context, it has been employed for a host of medicinal purposes - it dulls hunger, can combat fatigue and is helpful with nausea and altitude sickness in the high altitude Andean region (Stolberg, 2011: 133). The leaf itself has no psychoactive effects, as established by a 1995 World Health Organization (WHO) study that was subsequently banned from publication by American officials (Goldacre, 2009). The fact that such a publication was banned, is testament to the hegemonic power of the United States in constructing global drug policy (especially in the 1990's), as well as the strength of ideas surrounding the coca leaf specifically. Coca was not processed into cocaine until the mid 1800 's when it was discovered by European settlers in the Andean region and became an important ingredient in a variety of commercial products, including Coca Cola (Stolberg, 2011: 137). Given the addictive qualities of cocaine and crack cocaine, the coca leaf (as well as cocaine and crack cocaine) is listed as a 'schedule 1' substance (highly restricted) in the UN Single Convention on Narcotic Drugs (1961: 26). Cultivation of the coca leaf 
is therefore illegal according to international law. Since the late 1960's consecutive American governments have essentially declared open war against the ovular, green leaves (Draper et al, 2009: 189). In hegemonic discourse, coca became synonymous with crack and cocaine, and cocaleros synonymous with drug dealers (Draper et al, 2009: 188).

Kohl and Farthing write that in Bolivia "the upper echelons of the drug trade were consistently tied to the highest levels of the country's political and military power" (Kohl and Farthing, 2010: 197). Coca cultivation for cocaine production began during former Bolivian dictator Hugo Banzer's first tenure as president in the 1970's. Banzer fostered the expansion of coca and cocaine paste production. Essentially, the cultivation of coca for cocaine production in Bolivia was established under the Banzer administration (Leons and Sanabria, 1997:199). When Banzer was ousted in 1978, however, links between government and the cocaine trade were more firmly established (Leons and Sanabria, 1997: 199). In response complaints from international governing bodies, President Luis García Meza, a former military general who ruled Bolivia as a dictator between 1980 and 1981, established the national Acopio de Coca ${ }^{16}$ to purchase surplus coca crops with the intention of diverting coca from cocaine production (Leons and Sanabria, 1997: 199). What actually transpired with the formation of the agency, was that the government paid cocaleros a very low price for their excess coca and then sold it at a much higher price to "selected traffickers who were friends of the government" (Leons and Sanabria: 1997: 199). At its height, coca plantations in the Chapare region comprised upwards of 400000 square $\mathrm{km}$ of land and an estimated $90 \%$ of coca grown was exported for the production

\footnotetext{
${ }^{16}$ My translation: coca agency
} 
of cocaine (Kohl and Farthing, 2001: 36). In the neoliberal context, coca cultivation came to comprise a very significant part of the Bolivian economy. Kohl and Farthing write:

From the mid-1980s to 1997, coca leaf and semi-processed cocaine paste provided an estimated US $\$ 500$ million a year or between 5 and $8 \%$ of GDP, exceeding all other agricultural products both in terms of value as well as in provision of jobs... Coca income from peasant producers supported around 50,000 families... Overall estimates of the number of people working in coca cultivation during this period ranged between 120,000 and 500,000. (2006: 74)

In light of how much Bolivian grown coca was eventually being channeled into cocaine production, efforts to eradicate coca plantations were easily justified in the eyes of both Bolivian and American officials. Efforts to eradicate coca in the Chapare region began in the late 1980's with President George H. Bush's Andean Initiative (Kohl and Farthing, 2006: 74). Coca cultivation was made illegal in 1988 with the introduction of Ley $1008^{17}$ (allowing legal coca cultivation in only a small area in the Yungas region in which coca could be produced for domestic consumption). Greg Grandin writes that the passing of Ley 1008 and the implementation of repressive eradication programs all occurred under "intense pressure" from the US government (2007: 216). Interestingly, upon Banzer's democratic election in in 1997, the former dictator took a markedly different stance to coca production than during his prior presidency. His second administration, which held office between 1997 and 2001, is often cited as being one of the most repressive worldwide in its efforts to reduce coca production in conjunction with American funds and USDEA operatives (Grandin, 2007: 216). The Banzer administration introduced Plan Dignidad ${ }^{18}$ which involved forced eradication of coca crops by military

\footnotetext{
${ }^{17}$ Translation: law 1008

${ }^{18}$ Translation: Plan Dignity
} 
and paramilitary forces (Kohl and Farthing, 2010: 201). Banzer's strategy of "Coca Zero" was hailed a success by the Clinton administration in the early 2000's in that the Chapare region was, for a short time, essentially coca free (Draper et al, 2009: 203).

Forced eradication efforts in the Chapare region, undertaken by the Bolivian military with US financial support, as well as by agents from the DEA and private security firms contracted out by USAID (Grandin, 2007: 216), were accompanied with much violence, resulting in the deaths of 33 coca growers, 27 military and police members, the injury of 570 coca growers, and the (often arbitrary) arrests of many more (Kohl and Farthing, 2010: 201). The forced eradication effort was accompanied with programs for financial compensation and for channeling production capacities into other outputs, as designed by the Banzer administration in conjunction with the DEA (Draper et al, 2009: 203). However, given a lack of resources and political will, these programs were never actually realized as the government claimed they would be, also in part because incentives were not great enough to steer poor farmers away from coca production (Draper et al, 2009: 203). Further, the eradication of coca dealt a serious economic blow to the livelihoods of cocaleros, the wider Chapare region, including the city of Cochabamba, and the wider Bolivian economy. While it is difficult to know the full economic impact, Kohl and Farthing write that eradication efforts under Banzer cost the economy of Cochabamba between $\$ 150$ and $\$ 500$ million per year (Kohl and Farthing, 2006: 158). Calls for compensation from the Banzer administration to the U.S. government to mitigate the economic fallout largely fell on deaf ears (Draper et al, 2009: 203). Ultimately, the successes in the early 2000's in eradicating coca were short lived, 
and given a lack of alternatives, coca growth resumed at levels close to that of the 1990's (Draper et al, 2009: 203).

Kohl and Farthing characterize the forced eradication approach as a "repression model" (2010: 198). The effort to eradicate coca plantations in the Chapare came under scrutiny from prominent international bodies concerned with human rights, like Human Rights Watch and the United Nations Human Rights Council, given reports of tactics of intimidation and the use of torture (Human Rights Watch, 1995). A report published by Human Rights Watch in 1995, prior to the election of Banzer and the shift towards an even more aggressive approach to eradication, highlighted the statements of the Assistant Secretary of State for the Bureau for International Narcotics and Law Enforcement Affairs, Robert Gelbard. In response to rising criticism of American intervention into the Chapare region and the human rights abuses associated with the effort, Gelbard said that in fact "counter-narcotics assistance can be a powerful force in advancing, rather than retarding, human rights objectives in the hemisphere" (Human Rights Watch, 1995). The report also posits that "U.S. officials dismiss or downplay abuses by the U.S.-supported Bolivian counter-narcotics forces" and that "Bolivian and U.S. public officials make excuses for or attempt to justify human rights violations in the context of the drug war" (Human Rights Watch, 1995). What is clear in examining the case of the Chapare is that for Bolivian and American officials, eradication came first and the livelihoods and most basic human rights of cocaleros came a distant second. While there have been efforts of 'alternative development' to compensate cocaleros for their destroyed plots and to create alternative paths for cocaleros to meet their most basic needs, many observers have cited 
that these efforts were rarely carried through nor effective in providing for those affected by forced eradication.

It is also important to keep in mind that efforts to eradicate coca coincided with the shift towards a neoliberal policy agenda. Facing crippling levels of inflation and the incapacity to service even the interest on its loans, Bolivia implemented an IMF prescribed structural adjustment program as a condition for the rescheduling of their incapacitating loans (Grandin, 2007: 202). In the early 1990's the U.S. government and the international financial institutions celebrated the Bolivian government for the enthusiasm and extent to which it enacted neoliberal reforms (Kohl and Farthing, 2006: 65-70). Already one of the poorest countries in the region, more Bolivians fell into poverty as public sector employment was drastically cut, employment became more precarious and there were few if any social safety nets to cushion the blow of a draconian structural adjustment program (Grandin, 2007: 202). In summarizing Bolivia’s experience with the neoliberal project, Grandin writes:

Inflation fell and the economy stabilized and even grew, but poverty rose to inhumane levels, engulfing 97 per cent of the rural countryside. Cheap imported food hammered the peasantry, which began to suffer from high levels of malnutrition and infectious diseases, while low-priced manufacturers led to the shuttering of hundreds of factories. Unions were busted and labor protections eviscerated, contributing to rising unemployment and longer workweeks for those lucky enough to hold jobs. (2007: 202)

In this context, coca production became increasingly important to the livelihoods of thousands of Bolivians living in the rural, coca growing regions. Grandin understands the push towards neoliberal reform as directly feeding in to Bolivia's "drug crisis," (Grandin, 2007: 202) given the few alternate means to make a living in the Chapare region and a weakened social safety net. Grandin also highlights that the liberalization of finance 
across South America facilitated the easy laundering of drug money through the increasingly unregulated banking sectors of various South American countries (2007: 202). Coca production was an attractive option in the Bolivian context since the conditions of the Chapare region were well suited to its growth, it could be harvested four times a year, the crop is relatively hearty and weighs substantially less than other agricultural outputs, which is of significance because transporting agricultural products out of the Chapare region is still often done by foot (Draper et al, 2009: 202). Furthermore, compared to other agricultural outputs, demand and prices for coca have remained relatively high and steady given the global demand for cocaine and its illicit nature (Draper et all, 2009: 202).

Forced eradication in an era of neoliberal governance had particularly dire consequences for those whose livelihood was dependent upon coca production and unsurprisingly, strong resistance emerged to the Bolivian government's actions in the Chapare region (Draper et al, 2009: 209). Movement around coca also occurred in a context of wider resistance to neoliberal government across the country, as exemplified by the 'Water Wars' in Cochabamba and the 'Gas Wars' in La Paz (Kohl and Farthing, 2006). While the MAS emerged out of a union of mainly indigenous cocaleros in the Chapare region, it found fertile ground for its ideas in a wider context that was characterized by disenchantment with the neoliberal governance of the decade prior. The start of the new millennia in Bolivia was characterized by political instability. Neoliberal policy prescriptions meant that quality of life had deteriorated to the extent that Bolivians were struggling to live even at the same levels their parent's had decades before (Kohl and Farthing, 2006: 3). Accordingly, Bolivians all over the country took to the streets in 
protest of the failed neoliberal policies of the 1990's, often being met by the military, leaving many dead and many more injured (Farthing and Kohl, 2006: 4). Bolivia saw high turnover of governments given the failure of consecutive administrations to respond to the rally cries of the citizenry (Farthing and Kohl, 2006: 4), until the election of Morales in 2006 and the ratification of a new constitution. We can understand resistance in Bolivia to the coinciding neoliberal and drug control projects through a Polanyian lens, whereby the negative impacts of free market reform and the eradication programs worked to facilitate the emergence of a strong resistance movement.

The US approach to coca eradication in Bolivia has closely mirrored efforts elsewhere in the region and internationally. The fact that similar eradication efforts were implemented in Peru and Colombia is reflective of policies being imposed upon peripheral countries by a hegemonic world order led by the United States, rather than being a reflection of a coincidental propensity for similar policy trajectories or similar preferences stemming from each respective state's electorate. In fact, given that in each country the implementation of the policies in question was both politically unpopular and met with resistance from the citizenry, we can understand the implementation of forced eradication programs as being fundamentally a reflection of the hegemonic power of the United States in the region. Further, the implementation of such programs by the governments in the Andean region is reflective of Cox's notion that the dominant consensus gains ideological recruits amongst elites in peripheral countries. Given the prominent position of the US in IOs that were central to the continued economic viability of each respective state, governments in the region had little choice but to submit to the demands of the US. 


\subsection{The Morales government and the emergence of a counter-hegemonic drug policy}

The Morales government, emerging from a union of cocaleros itself, has taken a markedly different approach to coca reduction than its predecessors. Morales has made every effort to consciously construct an alternate hegemony concerning the management of coca within Bolivia's borders. If we take Gramsci's notion of 'wars of position' and apply it to the international stage, we can come to understand that resistance to the dominant drug policy orthodoxy in Bolivia can be classified as such, in that it actively tries to disrupt hegemonic ideas surrounding coca and how the problem of illicit drug production should be managed. This is articulated in a government document released in 2011 that outlines the Bolivian government's strategy for fighting the narco-traffickers and managing the drug problem:

...Bolivia busca que la lucha contra el narcotráfico se realice a partir de la construcción de una identitdad sudamericana, tomando en cuenta los compromisos internacionales previament adquiridos, las lesilaciones nacionales y en especial el cumplimiento de los principios de soberaía, autodeterminación, no intervención y las prácticas culturales propias de cada país. ${ }^{19}$ (2011: 13)

The strategy articulated here can be understood as in direct opposition to the approach propagated by U.S. officials operating in Bolivia prior to the election of Morales, given its sensitivity to cultural uses of coca as well as being based on principles of nonintervention and self-determination. In this sense it is counter-hegemonic. We can further

\footnotetext{
${ }^{19}$ My translation: Bolivia is looking for the struggle against narco-trafficking to take place based upon the construction of a South American identity which takes into account the previously acquire international agreements, national legislations, and is especially cognizant of the principles of sovereignty, self determination, non intervention and the respective cultural practices of each country.
} 
understand Bolivia's approach to drug policy as counter-hegemonic in that the approach transcends economic considerations. In employing an alternate strategy and expelling the USDEA and other U.S. officials from Bolivia based on their approaches to coca reduction, Bolivia has faced financial ramifications. While such actions may not have been possible a decade ago, in a context in which U.S. hegemony is waning and in which the principles of neoliberal governance have been largely discredited in the South American region, shifting relations of power have allowed for counter hegemonic policy shifts (not only in the area of drug policy). This is in line with the neo-Gramscian notion that norms shift in relation to shifts in power relations.

In Bolivia, given the experience of the last three decades, the coca leaf has become symbolic of a history of foreign powers violating Bolivian sovereignty and meddling in its internal affairs (Draper et al, 2009: 209). Grisaffi argues "as a script for identity, (the) coca leaf stands for the continuity and coherence of key concepts, such as sovereignty, nation and indigenousness" (2010: 427). In that the MAS emerged from organization around coca and resistance to eradication in the Chapare region, we have to understand Bolivia's recent experience with U.S. funded eradication projects as one of the factors that led to the rise of the MAS. The construction of an alternate hegemony concerning coca and coca cultivation in Bolivia has occurred in a wider context of resistance to U.S. neo-imperialism in Bolivia. Anti-American and anti-imperial statements characterized the rhetoric of Morales's rise to power. Accordingly, relations between the two countries have become increasingly strained over the course of Morales's presidency. On September 10th, 2008 Morales expelled American ambassador Philip S. Goldberg on charges of undermining Bolivian democracy and sovereignty in the 
form of espionage and funding the opposition (Romero, 2008). On September 10th, Morales addressed the Bolivian people: "Without fear of the empire, I stand before the Bolivian people today and declare United States Ambassador Mr. Goldberg persona non grata" (Friedman-Rudovsky, 2008). The US State Department in turn issued a statement expressing their dismay with Morales's decision saying that Morales's decision would "prejudice the interests of both countries, undermine the ongoing fight against drug trafficking, and will have serious regional implications" (US State Department, 2011). In a tit for tat move, the United States went on to expel the Bolivian ambassador, Gustavo Guzman the next day (BBC News, 2008). As of 2014, while both countries maintain embassies, in both countries, the position of ambassador remains vacant, symbolizing the sustained tension between the two countries. In 2009, Morales put an end to the US DEA's longstanding stint in the Chapare region based on charges of espionage and couched in principles of "dignity and sovereignty" (Farthing and Kohl, 2010: 13). In turn, Bolivia found itself on the American anti-narcotics 'blacklist' (New York Times, 2008). Subsequently, in re-negotiating the terms of the Andean Trade Preference Act, George W. Bush decided to limit the economic activity that went on between the two nations in saying, that as Bolivia had "failed to cooperate with the United States on important efforts to fight drug trafficking," the United States would "suspend Bolivia's trade preferences" (2008). Despite the shift away from a neo-conservative foreign policy strategy in the United States with the election of Obama, and Obama's less invasive approach to drug policy in Latin America than his predecessors, relations between the two countries have remained tense. Discussing American involvement in Bolivia at a UN press conference in 2011, Morales said: 
Do you think Obama would accept a contribution of the Bolivian Government for the Republican Party? That is what the United States does in Bolivia. We do not accept this. It is a political interference. It is a lack of respect for the Bolivian people and its Government. (2011)

In the last of a series of dramatic foreign policy moves made by Morales, in 2011, Bolivia pulled out of the UN Convention on Narcotic Drugs in protest over its tenets surrounding coca production and the refusal of member nations to remove the coca leaf from the list of banned substances (2011). At a UN press conference in 2011, Morales addressed the sustained tensions between the two countries with reference to the aggressive nature of the war on drugs. His statements offer insight into both the hegemonic and counterhegemonic constructions of the war on drugs:

Those of us who head the social struggle for vindication are called terrorists. I have been accused of being the Andean Bin Laden in Bolivia. Lately it's no longer communist or terrorist, but drug trafficker. It was within that context that we received information about false accusations that the presidential airplane had been detained for traces of cocaine. It is a lie... I am very afraid of the United States Government because I know their political operators. They always use drug trafficking with geopolitical interests. The American DEA did not combat drug trafficking. They used drug trafficking for political ends. (2011)

Morales's strongly worded statements have emerged in a context of widespread disenchantment with American involvement in Latin American politics and a shift away from neoliberal governance, particularly in the South American region. It is in this context, in which relations of power are shifting, that we have seen the creation of spaces for alternate imaginings of how to manage the issue of narcotic drugs.

Morales's initiatives related to coca can be summarized as a shift in policy direction at the domestic level and the propagation of new ideas surrounding the coca plant and its cultivation at the international level. Morales has spearheaded a campaign, 
entitled 'control social ${ }^{20}$ to reduce coca on a farmer-by-farmer basis, allowing cocaleros to cultivate enough coca to sustain their livelihoods while promoting reduction. Morales also initiated significant reforms to existing legislation. Specifically, the Morales government made significant amendments to ley 1008 , that deemed coca production and coca chewing criminal offenses, based on the premise that the existence of the law itself was premised on "sometimiento a exigencias externas"21 (República de Bolivia, 2007: 42). Further, the Morales government has undertaken an effort to diversify the range of products made out of coca leaves and to improve the industrial capacities associated with them in partnership with the Venezuelan government. Kohl and Farthing characterise this strategy as a "dramatic break from the past" (Farthing and Kohl, 2010: 198). Morales' strategy has been successful in reducing overall coca cultivation in the region and has not been characterised by the protest, repression and human rights abuses that were associated with Banzer's 'coca zero' strategy. The remainder of this chapter will discuss Morales's initiatives of 'control social' and 'coca diplomacy' in more detail.

\section{i) Bolivia and 'control social'}

The construction of a new hegemony surrounding drug production in Bolivia has been contingent upon the success of Morales's approach to coca reduction. Morales initiated a strategy of 'control social,' whereby coca production is monitored and a given plot is only allowed to produce so much of the crop (2010: 205). Kohl and Farthing describe the strategy as follows:

\footnotetext{
${ }^{20}$ Translation: social control

${ }^{21}$ My translation: Submission to foreign demands
} 
While validating the historical and current importance of coca to Andean culture and economy, the Morales government seeks to turn the leaf's medicinal and nutritional benefits into an advantage while aggressively controlling drug trafficking. Within this framework, priority is given to a nonviolent solution to the complex problem of reducing the amount of coca leaf that ends up as cocaine. Instead of treating coca growers as enemies of the state, the government works to include them as partners in developing solutions. (2010: 205)

Morales' strategy is not premised on naïve notions that we can totally eliminate the supply of cocaine, and therefore the demand for it. Rather, the strategy aims to limit the amount of coca destined for cocaine production (2010: 205).

This new approach has been successful in reducing coca production and has not been characterized by the violence, repression, and protest that other strategies to eradicate coca have been. The concept of 'social control' is based on principles of "preHispanic indigenous community organization to privilege collective over individual rights" (Farthing and Kohl, 2010: 205). Close partnership between the government, unions and peasants lends a sense of legitimacy to eradication efforts. Evidence of this is in the fact that Morales's strategy has not met the same levels of resistance to eradication or violence as those of previous administrations. Under Morales, Bolivia has eradicated over 36,000 hectares of illegal coca plantations since 2009 (UNODC, 2012). This is comparable to the amount eradicated under former administrations, which has leant credibility to the new approach and has prompted the UNODC to up funding for Bolivian monitoring efforts (Kohl and Farthing, 2010: 207). The government works in conjunction with unions of cocaleros to eradicate coca that is planted outside the boundaries of the law. Under the Morales government, the coca leaf is no longer dealt with through military intervention, moving away from an approach characterized by securitization. The vast majority of coca eradication under Morales has taken place voluntarily, in comparison to 
previous efforts in which the military was sent in to forcibly eradicate coca crops (Kohl and Farthing, 2010: 207). Further, illicit drug seizures under the Morales administration have increased significantly (Estado Plurinational de Bolivia, 2011: 52). While in the early 2000s the Bolivian government seized 4 metric tons of "illicit drugs," in 2010 drug seizures were up to 29 metric tons (Estado Plurinational de Bolivia, 2011: 52). This is in part because of changing patterns of drug production and trafficking whereby more processed drugs are making their way through Bolivia than before, but can also be attributed to improved interdiction efforts under Morales.

Under Morales, the legal production area now encompasses 50000 hectares of coca plantations (Kohl and Farthing, 2010: 205). The effort also aims to create a range of new products using the coca leaf - from cakes, to tooth paste - and has made an effort to improve industrial capacities related to churning coca leaves into new outputs in conjunction with Venezuela (Draper et al, 2009: 206-209). There is evidence to suggest that international demand for coca teas and tonics exist given its medicinal benefits (Kohl and Farthing, 2010: 205). It is however unclear how much legally produced coca in Bolivia goes to initiatives like these and for domestic chewing and tea production. As such, the U.S. government has voiced concern that the increase in size of the legal production area will lead to increased cocaine production (Kohl and Farthing, 2010: 208).

Within Bolivia, there is concern that the allocated amount of coca that each farmer can produce is too little to provide the basis of a viable living. This being said, socioeconomic conditions in Bolivia have improved significantly under Morales's governance and with the end of the neoliberal era. Although Bolivia faced setbacks during the global financial crisis between 2007 and 2009, since 2009 GDP has climbed 
every year (ECLAC, 2013). Further, as of 201136.3 per cent of Bolivians live below the poverty rate (ECLAC, 2013). Although an alarming number of Bolivians are still living in poverty, considering that in 200063.7 per cent of Bolivians lived below the poverty line (ECLAC, 2013), strides have been made towards reducing poverty. It must of course be noted that Morales's success is contingent upon the rise in price of minerals and the nationalization of highly profitable industries like the natural gas industry (Farthing and Kohl, 2012: 225).

Increasingly, the international community is expressing its support for Bolivia's approach to managing coca production. This is exemplary of the early stages of the diffusion of a new international norm, as previously it would have been very unlikely that an IO like the OAS or mainstream media outlets would condone such a policy direction. In discussing the implementation of alternate development projects in conjunction with forced eradication and aerial spraying efforts, the OAS report states:

The association of alternative development with law enforcement activities, including eradication and aerial spraying, has had a negative impact on the attitudes of the communities directly involved.... Without the participation of these communities there is no chance of developing effective alternative crop programs. (2013: 34)

After describing the Bolivian strategy the report writes that evidence suggests that in Bolivia, "eradication investments have had some success in curbing production at the local level" (2013: 34). Further, mainstream media outlets have picked up on the successes of Morales's strategy in reducing coca, as evidenced by a 2008 article in Time Magazine that writes, 
Coca cultivation is under control and drug trafficking interdiction is up. Morales has managed to meet at least some of the goals of the U.S. on his own terms, without turning into an enemy of his own people. (2008)

The success of Morales's effort of 'social control,' in reducing illegal outputs of coca while maintaining domestic harmony, and the fact that the international community is not only condoning, but applauding Morales's efforts, lends credibility to Morales's new hegemony. The liberal theorists would argue that we see the emergence of new norms when the old norms have been discredited. Morales's successes in the area of coca reduction have discredited the American approach in that forced eradication efforts saw little success in actually reducing the amount of coca produced in Bolivia and resulted in profound political turmoil. Kohl and Farthing write,

Bolivia's recent policy innovations on coca bring a fundamentally new approach to the hemisphere's long-standing debates over how to control drug trafficking, one that repudiates decades of policies arising from the U.S.-driven drug war. (Kohl and Farthing, 2010: 209)

We can understand Bolivia's experience with 'control social' counter-hegemonic in that it works to disrupt dominant ideas about the coca leaf and the management of illicit drug production. In light of the success of Morales administration's strategy, Bolivia is helping to reconstruct internationally held ideas about how the drug problem should be managed. Given Bolivia's tumultuous experience with the War on Drugs, Morales maintains strong support in Bolivia, and it is likely he will win the upcoming election in late 2014 (BBC, 2014).

ii) The UN Special Dispensation 
If we premise our analysis on Cox's claim that international institutions act as agents of ideational hegemony, we can understand the recent 'special dispensation' at the UN as being very significant and representative of the breakdown of hegemonic, U.S. espoused discourse surrounding the war on drugs. The achievement of a 'special dispensation' for Bolivia essentially means that Bolivia's obligations related to the 1961 Convention differ from those of other signatories, based on context specific, cultural norms and preferences. As previously mentioned, the 1961 Convention on Narcotic Drugs stipulates that the coca leaf is a 'schedule 1' substance and that coca production under most circumstances and for most purposes is illegal. Further, according to the convention, coca chewing is an unlawful practice and was to be phased out over a 25year period. In 2009, the government of Bolivia put forth an amendment to the 1961 Convention that would make the cultivation of the coca leaf for traditional and cultural purposes legal, worldwide (OAS, 2013: 31). Subsequently, in 2011, 18 countries, including Canada, the United States, Mexico and France (Transnational Institute, 2011), submitted objections to the amendment, prompting its failure (OAS, 2013: 31). While those submitting objections did so on based on the argument that Bolivia's amendment would affect the integrity of the convention, interestingly, the "Report of the Global Commission on Drug Policy" articulated a very different position concerning Bolivia's failed amendment:

When these [new strategies and programs] involve a more tolerant approach to drug use, governments have faced international diplomatic pressure to 'protect the integrity of the Conventions,' even when the policy is legal, successful and supported in the country. A current example of this process (what may be described as 'drug control imperialism'), can be observed with the proposal by the Bolivian government to remove the practice of coca leaf chewing from the sections of the 1961 Convention that prohibit all non-medicinal uses... The idea that the international drug control system is immutable, and that any amendment - 
however reasonable or slight - is a threat to the integrity of the entire system, is short sighted. (2011: 8)

To describe the aforementioned process as 'drug control imperialism,' in a mainstream publication, is a reflection of the degree to which the international discourse is changing. The Bolivian government proceeded to pull out of the convention in protest of the tenets surrounding coca chewing with the intention of re-acceding contingent on the addition of a special reservation for Bolivia (OAS, 2013: 31). The Bolivian representative at the UN, Pablo Salon, highlighted the statements of the Global Commission's report in pulling out of the convention (2011). And so, taking its failure in stride, the Morales administration lobbied for the addition of a clause that deems coca chewing a lawful practice based on traditional and cultural grounds. In January of 2013, Bolivia was successful in achieving a 'special dispensation' at the UN that stipulates:

The Plurinational State of Bolivia reserves the right to allow in its territory: traditional coca leaf chewing; the consumption and use of the coca leaf in its natural state for cultural and medicinal purposes, such as its use in infusions; and also the cultivation, trade and possession of the coca leaf to the extent necessary for these licit purposes. At the same time, the Plurinational State of Bolivia will continue to take all necessary measures to control the cultivation of coca in order to prevent its abuse and the illicit production of the narcotic drugs which may be extracted from the leaf (2011).

This special dispensation received overwhelming support from the international community with only 15 countries, including Canada and the United States, rejecting the special dispensation (2011). This overwhelming support is indicative of a shift in the balance of power within international institutions and a changing discourse surrounding drug control in international arenas. Such a dispensation would have been unthinkable likely even ten years earlier when Bush was in the White House. The dispensation can be taken as a chink in the War on Drugs armor in that it will work to de-legitimize future 
efforts at forced eradication should the War on Drug effort reconvene in a more aggressive way in Bolivia. Further, the dispensation could have the potential to open up new markets for Bolivian exports that feature coca as an ingredient, like coca tea, coca flour and coca wine. The 'special dispensation' is evidence of a shifting global discourse on drug production and reduction facilitated by the Morales administration's efforts to reconstruct hegemonic notions of coca and cocaine. This development is quite simply unprecedented given the past trajectory of global drug policy.

Ideally, the Morales government would eventually like to see the coca leaf removed from the list of banned substances on the 1961 Single Convention in order to open up a legal, international market for products derived from the leaf. The European Union has been much more progressive in its stance towards the importation of coca leaves for licit uses in its member nations. The European Parliament, 2008 "Green Paper on the role of civil society in drugs policy in the European Union" called upon member nations to

... Explore ways of cooperating with EU civil-society organizations involved in promoting substances derived from coca leaves for lawful use purely as a means of contributing effectively (by absorbing raw materials) to international action against drugs trafficking, ensuring at the same time the safe use of such substances. (2008)

While diversifying the range of products derived from the coca leaf and marketing them to an international market would help absorb coca crops that would otherwise be destined for cocaine production while helping poor, Bolivian farmers maintain their livelihoods, the international legalization of the coca leaf is unlikely given American opposition to both Bolivia's original amendment and subsequent special dispensation. 
From a neo-Gramscian theoretical perspective, Bolivia's success in achieving a special dispensation at the $\mathrm{UN}$ is significant, given that none of the actors involved in eventually shepherding through the dispensation can be understood as either members of the transnational elite or subscribers to the dominant hegemony. From a neo-Gramscian perspective, Bolivia's success in achieving a special dispensation can be taken as reflective of shifts in the balance of power at the UN rather than contingent on the success of 'moral entrepreneurs' in lobbying for the formation of a new international norm. Morales and his administration cannot be understood as members of the transnational elite in the same way that, say, the members of the Banzer administration could, given that Morales and members of his administration have on several occasions explicitly articulated that their government stands in direct opposition to the objectives of the United States on a range of issues and have articulated their desire to construct a posthegemonic regime in Bolivia. Accordingly, the success of Bolivia in achieving this special dispensation is contingent upon the fact that the global prohibition regime is increasingly being discredited and we are seeing the breakdown of hegemonic ideals surrounding drug management and the breakdown of U.S. hegemonic power in the South American region. We can however understand the issuance of the 'special dispensation' as contributing to the construction of a new hegemony surrounding drug policy management, which is perhaps more in tune with more localized constructions of various substances. Further, a shifting balance of power at the international level means that increasingly, actors who were once sidelined in the construction and maintenance of global hegemony are increasingly taking part in its reconstitution. 


\subsection{Conclusion}

In a sense, we cannot argue that Bolivia's strategy at coca reduction is entirely counter-hegemonic in that, to an extent, Bolivia is still submitting to the desires of the US and the UN in taking part in coca eradication at all. However, we can argue that Bolivia is engaged in a 'war of position' in that it is discrediting the orthodox discourse and policies surrounding coca eradication and consumption. Further, in enacting policies that are in opposition to the US espoused approach to drug control, the Bolivian government has faced financial ramifications given that in the past, much of the budget for counternarcotic efforts came from the US government. The success of Bolivia in reducing coca production and receiving the 'special dispensation' at the UN opens up a new window for re-conceptualizing the global approach to drug control. By embracing a strategy of coca reduction that differs substantially from American efforts, the Bolivian experience has lent legitimacy to this new anti-war on drugs discourse emerging and sets the stage for the evolution of a new hegemony while simultaneously discrediting the old policies. The construction of a new hegemony emerging out of Bolivia is contingent upon the Morales government's success in reducing coca production in Bolivia while managing to avoid the turmoil that has characterized past strategies. While we have to understand Bolivia's counter hegemonic discourse and its success as emerging in a context that is perhaps ever so slightly more receptive to it, we can take the adoption of the 'special dispensation' as evidence of tensions in the global prohibition regime. 


\section{Chapter: Case study - Guatemala}

Guatemala is neither a major producer nor consumer of illicit drugs. But by virtue of geography, increasingly the country has been caught in the War on Drugs cross fire. Changing patterns of drug trafficking in response to stepped-up interdiction efforts on behalf of Mexico, Colombia and the United States as well as the spillover of Mexican cartel violence in primarily Guatemala's Northern region, mean that the country, which once was left out of the turmoil of the war on drugs, is feeling the violence associated with the drug trade in Latin America. Interestingly, Guatemala's current president, Otto Pérez Molina, despite his right-wing position on the ideological spectrum, has taken an unconventional stance on the issue of illicit drugs. The ex-military general has made very public statements, including statements at the United Nations and the World Economic Forum, calling for the legalization of all drugs as a result of what he perceives as the failure of the war on drugs effort. While many ex-presidents have made similar calls, or called for de-criminalization rather than legalization, Pérez Molina’s calls for drug legalization are exceptional given that he is a sitting president. Taking such a stance is often politically unpopular (Breaking the Taboo, 2013), especially in a country like Guatemala where the church plays a significant role (CIA World Fact Book, 2014), and many hold socially conservative views on issues like gay rights (Immigration and Refugee Board of Canada, 2006) and abortion. Pérez Molina's position exemplifies the emergence of a counter-hegemonic discourse pertaining to how to manage the production and consumption of drugs and how this discourse is coming to pervade ideological position. This chapter will first provide background information on the Guatemalan experience with drug trafficking and drug related violence. Next, this chapter will turn to 
the election of Otto Pérez Molina and explore his presidency to establish that holding such views while maintaining the ideological position that he does is anomalous. Finally this chapter will analyze the statements made by Molina to support the argument that we are seeing the emergence of a new global hegemony that transcends ideological lines.

\subsection{Violence in Guatemala}

The small Central American country of Guatemala is no stranger to violent conflict. It was only in 1996 that a peace accord was signed, putting an end to a 36-year civil war in which consecutive right-wing authoritarian governments, backed by the US government in the Cold War context (Deibert, 2008: 168), were complicit in the slaughtering of hundreds of thousands of indigenous Guatemalans. Between 1960 and 1996, military affiliated death squads fighting against leftist guerilla groups composed primarily of the indigenous, rural poor, killed an estimated 200,000, primarily indigenous, Guatemalans and displaced an estimated one million more (Deibert, 2008: 168). Half of these causalities occurred in the bloodiest years of the conflict between 1981 and 1982 (Brands, 2010: 11). Given that the population of Guatemala grew from only 4.4 million at the start of the civil war in 1960 to 10.2 million when the peace accord was signed in 1996 (World Bank, 2014), the devastation wrought by the conflict was immense, and the legacies are still felt deeply.

While Guatemala has experienced some economic growth since the end of the conflict, as of $2011,53.7 \%$ of Guatemalans live below the poverty line (World Bank, 2014), and as of 2012 GNI per capita, sat at around \$3,100 (World Bank, 2014), making it not only one of the poorest countries in the Latin American region, but also in the 
world. Further, the peace process outlined in 1996 has never been fully realized in Guatemala (Tran, 2011). This is in part because most of those responsible for the atrocities during the civil war have not been subject to any sort of punishment. Top officials during the civil war still occupy prominent positions in the Guatemalan bureaucracy (Tran, 2011). President Otto Pérez Molina, for example, was one of the leading negotiators for the military junta during the peace negotiations. Further, a generation of Guatemalans has grown up knowing nothing other than armed conflict, and many of them are trained in conducting warfare and little else (Brands, 2009: 12). Guatemala remains a country with one of the highest murder rates in the region, no doubt in part due to legacies of structural racism, corrupt police and military forces still composed of individuals who inflicted horrific violence upon the indigenous Guatemalan population during the civil war. Further, violence often goes unpunished, given a corrupt judicial system, ill equipped and without the resources to deal with the high levels of violent crime that grip the country (only around $2 \%$ of crimes in Guatemala are subject to prosecution (Human Rights Watch, 2013)) (Tran, 2011). In that Guatemala is a country plagued by high levels of poverty and low levels of institutional capacity to deal with crime, it is of little surprise that Mexican cartels have found fertile ground for both their trafficking and production operations in Guatemala.

The Mexican cartels are thought to have begun conducting operations in Guatemala beginning in 2007 (Brands, 2009). This was largely in response to two developments in the War on Drugs effort. The first was stepped up interdiction of cocaine being trafficked by sea and air by both the Colombian and Mexican governments, in conjunction with the US government beginning under Bush (Meiners, 2009). While the 
bulk of trafficking had previously been done by sea or air, increasingly, trafficking is being done by land. Air and sea routes were favoured given the presence of rival criminal organizations along trafficking routes, logistical difficulties in orchestrating and cooperating with other criminal groups to ensure the supply's safe passage and the sheer difficulty of making such a journey given the poor road conditions of the Pan-American highway (Meiners, 2009). While in 2008, an estimated 8 tonnes of cocaine were trafficked through Guatemala, it is now estimated that $80 \%$ of cocaine destined for US markets travels through Guatemala (US Department of State, 2013). To put this in perspective, annually it is estimated that around 600 tonnes of cocaine are trafficked from South to North America, meaning an estimated 480 tonnes now travel through Guatemala (OAS, 2013: 47).

The second factor that drove Mexican cartel operations across the Southern border was stepped up military efforts in the North of Mexico under President Calderón. Calderón deployed upwards of 50,000 troops to the region, resulting in violent struggles between military forces and the cartels (Adams, 2011). The northern region of Guatemala presented an attractive locale to conduct operations for Mexican cartels like Los Zetas and Sinoloa, given the porous border between Guatemala and Mexico, the presence of criminal networks and youth gangs for the cartels to work in conjunction with and the low capacity of Guatemalan security forces (Adams, 2011). What has transpired is not only a struggle between the two cartels for control over trafficking routes, but the terrorizing of communities (Adams, 2011), and bids and threats for the favour of Guatemalan politicians (Brands, 2009: 17). While violent crime in Guatemala was a 
common occurrence prior to the entry of the cartels, levels of violence have been exacerbated by the presence of cartels.

In recent years, homicide rates in Guatemala have climbed above civil war levels. While the number of intentional homicides dropped in the post peace accord context between 1999 and 2003, to, at their lowest, 24.2 homicides per 100,000 inhabitants, by 2003, the homicide rate sat at 35 - virtually the same level it did in 1996 at the end of the civil war (UNODC, 2014). In 2005, in the lead up to the election the homicide rate climbed for the first time in decades, to above 40 to 42 homicides per 100,000 inhabitants (UNODC, 2014). As the cartel's established their stronghold over parts of Guatemala, we saw the homicide rate climb even higher, to a peak of 46.3 in 2009 (UNODC, 2014). While the rate has since dropped to 34.5 in 2012 (Overseas Security Advisory Council, 2014), Guatemala remains to be one of the most violent countries in the hemisphere and even the world. An even more concerning picture is painted if we examine the statistics for Guatemala City. While statistics are only available for the homicide rate, beginning in 2004, between 2004, prior to the entrance of the Mexican cartels, and 2009, we saw the homicide rate climb from 94.7 to 118.3 (UNODC, 2014). While the homicide rate has since dropped slightly, a 2009 article in The Guardian highlighted that Guatemala City was the second "deadliest" city in the world, after Caracas, Venezuela (Burn-Murdoch, 2012). Given that only $2 \%$ of crimes are prosecuted through the Guatemalan court system, the vast majority of murders in Guatemala are committed with impunity. As we see a clear spike in the homicide rate corresponding to the entrance of the cartels, it is evident that their presence has exacerbated violence in Guatemala. We also must keep in mind that the homicide rates do not reflect the range of other activities that the cartels, 
and those working alongside the cartels, partake in that make life increasingly difficult for, and evoke fear among the Guatemalan population.

Although it is difficult to gage the net worth of individual cartels, the US Justice Department estimates that Colombian and Mexican cartels generate between $\$ 18$ and $\$ 39$ billion USD annually in the sale of cocaine alone (Keefe, 2012). This figure excludes their other activities, which include the trafficking sale of opium and marijuana, extortion, arms trafficking, human trafficking and kidnapping for ransom. Comparatively, the annual budget for the federal government of Guatemala for 2013 , sat at $\$ 7.8$ billion USD (CIA World Fact Book, 2014), a fraction of which is spent on security initiatives. What is clear in the Guatemalan case is that the state simply does not have the resources, or the institutional capacity, to contain the cartels.

Also of concern related to the recent entry of the cartels in Guatemala, are the efforts of organized crime syndicates to influence politics and infiltrate the military and judicial branches of government. The 2007 election is cited as one of the bloodiest in Guatemala's history, with upwards of 30 candidates and political activists disappearing or being murdered (Lacey, 2007). Evidence suggests that the murder of candidates was linked to cartels trying to influence the election results in such a way that those politicians favourable to the cartels would take office, and to make clear that acting against the cartels' interests entails serious ramifications (Brands, 2009: 17). Criminal organizations have been successful in infiltrating police and military forces, the judicial branch and even some of the highest levels of the administrative branch. Former President Alvaro Colom even fired two of his top aides in 2007 for supposed links to the drug cartels and allegations of bugging his office on behalf of cartel members (Brands, 
2009: 16). Given the resources of the cartels and their proclivity for violence, coupled with the incapacity of the police force and criminal justice system, one can imagine it is difficult for Guatemalan politicians to not fall into the hands of criminal organizations. Further, as many of the individuals who perpetuated the violence during the civil war continue to hold positions of power in Guatemala and have maintained their propensity for criminal activity, it isn't difficult to understand how the cartels have managed to wield influence.

\subsection{The Election of Otto Pérez Molina}

It is out of these circumstances that Guatemalans, concerned with the climbing murder rates and the incidence of day-to-day violence, elected retired military general and founder of the right-wing Partido Patriota, Otto Pérez Molina to the presidency. Security was one of the primary issues upon which the election was fought. Pérez Molina's tough on crime stance prevailed over the centrist candidate, Manuel Baldizòn (BBC, 2011). Pérez Molina's election in 2011 elicited concern from the international community because of allegations against him of human rights abuses during his time in the military during the civil war (Human Rights Watch, 2013). Although few of the allegations have been substantiated, and Pérez Molina himself adamantly denies any wrong doing, as a high level general in the Guatemalan army, he is accused of taking part in "scorched earth" campaigns, whereby military forces effectively wiped out entire villages, slaughtering thousands of indigenous people and burning their villages to the ground (Human Rights Watch, 2013). Even U.S. intelligence cables coming out of 
Guatemala in the early 1990s alleged that, although Pérez Molina was a moderate and a democrat, he likely "had blood on his hands" (George Washington University, 1994).

In contrast to Latin American leaders like Evo Morales, Otto Pérez Molina has not been overly critical of the role that the United States plays in the hemisphere. Conversely, Pérez Molina came to power on a platform that would seek more US funds for anti-narcotic security initiatives in Guatemala and has since participated with the United States in efforts to control to the cartels (U.S. Department of State, 2013). Speaking to the General Assembly in September of 2013, Otto Pérez Molina made clear that, unlike other leaders in the region, he holds little if any disdain for the US government and their activities in the region:

We have expressed to the Government of the United State of America our clear interest in aligning our policies with those that promote progress between Mexicans and Americans. Guatemala wishes a tripartite alliance of progress with Mexico and the United States that serves as a pivot for a solid link with the countries of the Central American Integration System. (2013)

The fact that he maintains a friendly relationship with the United States is not surprising, given that Pérez Molina was educated at the School of the Americas, a US training center for Latin American armies. The School of the Americas has been the subject of much public debate and criticism over the last few decades given that several of its graduates have gone on to commit genocidal atrocities. As Lesley Gill writes, "Critics assert that... Latin American soldiers learn the repressive tactics of counterinsurgency warfare, that pits soldiers less against guerilla insurgents and than against poor peasants and civilians.”(2004: 6)

In her book, entitled The School of the Americas, Gill explores how, "the United States bought the collusion of Latin American security forces in the aftermath of World 
War II and how, over the course of the $20^{\text {th }}$ Century, it transformed these entities into extensions of its own power in Latin America," (2004: 7). Many have argued that the School of the Americas is as much a school of ideological indoctrination as an exercise in military training (Gill, 2006: 7). We can understand it as an overt exercise in gaining ideological recruits in peripheral countries. Given Pérez Molina’s education at the School of the Americas and his close working relationship with the US government, we can understand Pérez Molina as an actor who normally works to maintain international ideological hegemony and who does not disrupt the status quo in a significant way. Prior to his time in the military, Pérez Molina studied business and international relations (CIDOB, 2013). While Pérez Molina was born into a middle class family in Guatemala City and rose to a position of prominence through his tenure in the military (CIDOB, 2013), we can characterize Pérez Molina as a member of the transnational elite, as outlined by Robinson, given his current level of affluence, his commitment to a neoliberal policy agenda, his ties to the United States and the fact that he likely has more in common with other members of the transnational elite than rural, Mayan campesinos in Guatemala.

\subsection{Pérez Molina's approach to managing the drug problem}

Otto Pérez Molina came to power on a platform of improving security in Guatemala. Pérez Molina's approach to containing the drug cartels has involved increasing military and police budgets and capacities, and increasing the presence of the Guatemalan military in regions where the cartels have established a strong footing (U.S. State Department, 2013). Increasing the presence of the military in a country where the 
military has not so long ago committed genocide upon its own people, with impunity, is of course a cause for concern, and the "re-militarization" of Guatemala has been controversial amongst the Guatemalan people (Alford-Jones, 2013). In October of 2013, when military forces containing a peaceful protest that involved a highway blockade in Totonicapán opened fire killing six protesters and injuring 30 more, these concerns were re-ignited, and Pérez Molina said the military would no longer respond to public protests (Human Rights Watch, 2013). However, given the magnitude of the drug related violence, it is unsurprising that such a strategy has been pursued.

The military continue to work alongside police forces in an effort to contain the violence. Pérez Molina has also worked in conjunction with the US government on antinarcotics efforts. Prior to Pérez Molina's election in 2012, in 2009 Guatemalan President Alvaro Colom signed on to the Merida Initiative. The security initiative, with the primary goal of stemming cartel violence in the north of Mexico, pledged $\$ 6.75$ million of USAID money for Guatemala's fight against the drug traffickers (USAID, 2009). Although the United States maintains a military aid ban against Guatemala because of the atrocities committed by the military in the civil war context, since 1996, the US government has spent $\$ 85$ million dollars fighting the drug cartels in Guatemala (Torrens and Ruiz-Goiriena, 2012). While spending was relatively low up until 2007, after the increase in violence after 2007, 2012 it peaked in 2012 at \$16 million USD (Torrens and Ruiz-Goiriena, 2012). The USDEA maintains an office in Guatemala City and there is evidence to suggest that American DEA military trained special agents are operating in Guatemala in the fight against the narco-traffickers (Savage, 2011). In the neo-Gramscian sense, we can understand Guatemala as a proto-state, in that it is not of vital importance 
to the continued viability of the world economy or the maintenance of a hegemonic global order, but hegemonic institutions and powers have an interest in its political stability because of the country's geographic location and the potential for spillover. It can also be viewed as a proto-state given its susceptibility to counter-hegemonic ideals, given its historical propensity for leftist movements and the magnitude of the situation in which it is in now.

Although we would expect Pérez Molina's approach to managing the drug problem to fall under conventional approaches of how to manage the drug problem, the new president has made very public statements in international channels that fall far outside the orthodox discourse and, even beyond the parameters of the new emerging discourse. In the early days of his presidency, Pérez Molina called upon member nations of the UN to review the failures of the Single Convention on Narcotic Substances and consider the decriminalization of most illicit substances, and in recent years his calls for reform have become increasingly radical. Pérez Molina has called for the international legalization of most illicit drugs based on the argument that prohibition has failed the countries of Latin America (Torrens and Ruiz-Goiriena, 2012). Speaking to the Associate Press in September of 2012, while acknowledging the addictive and destructive qualities of cocaine and heroin to one's health, Pérez Molina proposed that such substances should be legalized, regulated and sold (albeit, with a prescription) (Torrens and Ruiz-Goiriena, 2012). He noted that Guatemala could not act alone in such an endeavor, as if the country was the only in the region where the movement and possession of such substances were legal, than Guatemala would run the risk of becoming a "open corridor" for drug trafficking and consumption (Torrens and Ruiz-Goiriena, 2012). As such, Pérez Molina 
has argued for an end to global prohibition and a move towards the legal regulation of substances like cocaine and heroin. He has premised his arguments on the failures of the prohibition regime and the destruction that prohibition and supply side policies have inflicted upon the countries of Latin America over the course of the last forty years. Speaking to the General Assembly in September of 2013, President Pérez Molina said, Since the start of my Government, we have clearly affirmed that the war against drugs has not borne the desired results, and that we cannot continue doing the same, waiting for different results... Without abandoning the path of international cooperation against transnational crime, each country must experiment with new models to address the drug problem. (2013)

During his address, President Pérez Molina also commended Colorado and Washington State for their moves to legalize and regulate the sale of marijuana, as well as Uruguay for moving away from the "failed route of prohibition" (2013). He spoke in a similar vein in discussing the effect that the drug war has had on his country in an interview with The Guardian in 2013. Discussing the penetration of organized crime into the Guatemalan bureaucracy, the President said,

Drug traffickers have been able to penetrate the institutions in this country by employing the resources and money they have. We are talking about the security forces, public prosecutors, and judges. Drug money has penetrated these institutions and it is an activity that directly threatens the institutions and the democracy of countries. (2013)

Interestingly, Pérez Molina employs similar arguments for the decriminalization and legalization of drugs to those made by prohibitionists in the 1980's and 1990's who argued for eradication on the grounds that the very existence of drugs were undermining democracy. It is difficult to situate Pérez Molina's counter-hegemonic statements in the Gramscian and neo-Gramscian literature, by virtue of his ideological position. We can 
understand his position through the lens of Polanyi and his conception of the "double movement," in that Polanyi stresses the role of the state in countermovement and mitigating the negative affects of the free market upon humankind. Given the alarming levels of violence associated with the drug trade in Guatemala, it is unsurprising that Pérez Molina would make calls for such drastic policy change. Pérez Molina's statements can be reconciled with his ideological position in that the levels of violence in Guatemala undermine the country's capacity for economic growth and to attract foreign investment. He has made clear that he believes attracting foreign direct investment is the means through which Guatemala will achieve economic growth as exemplified by a statement made to the General Assembly in September of 2013 in which he said "we are making progress in establishing our country as one of the leaders in improving the business climate to stimulate investments." We can thus understand his calls for policy change as being linked to the economic development goals of his administration.

US officials were quick to respond to President Pérez Molina's first statements calling for the deregulation of illicit substances and alternative imageries of the global prohibition regime. The US embassy in Guatemala issued a press release soon after the issuance of statements by Pérez Molina that called for new drug regulation measures that expressed the United States' continued commitment to prohibition. In reference to such measures as deregulation, the press release reads, "the United States continues to oppose such measures because evidence shows that our shared drug problem is a major public health and safety threat" (2012). It opposes such measures based on a correlation between drug consumption and violent crime (2012). In discussing the situation in Guatemala, and the wider Latin American region, the press release states, 
If the trafficking and use of illegal drugs were decriminalized tomorrow in Central America, transnational criminal organizations and gangs would continue to engage in illicit activity, including trafficking in persons and illegal arms, extortion and kidnapping, bank robbery, theft of intellectual property, and money laundering. Corruption and homicides in Central America are certainly exacerbated by the transit of illegal drugs, but with increased cultivation and consumption of decriminalized drugs, crime in Central America could well increase as the drug cartels shift their focus to these other forms of illicit activities (2012).

These sentiments were echoed by US Vice President Joe Biden on an official visit to Guatemala several weeks later (CNN, 2012). Although Pérez Molina's statements can be reconciled with his ideological position, given that his statements are in direct contention with the position espoused by officials of the United States government, we can classify his statements as counter-hegemonic.

President Pérez Molina's statements are anomalous in that he is the sitting president of a primarily Catholic, socially conservative country. While Pérez Molina does not have his eye on reelection (as presidents in Guatemala are only permitted to sit one term), he does have an interest in the continued success of the Partido Patriota, which is the political party that he founded. The legalization, or even decriminalization, of narcotic substances has historically been a politically unpopular position, and past sitting Presidents have been wary to touch the issue (Breaking the Taboo, 2013). Further, it is surprising that one of the biggest and most outspoken advocates in Latin America for the legalization of drugs is a leader who self-identifies as Roman Catholic and ideologically conservative and is friendly to the United States. This is also surprising given the recent shift towards leftist governance in many countries in the region and the left's historic propensity to be softer on the issue of narcotic drugs. In this sense, Gramscian and neoGramscian conceptions of resistance cannot account for Pérez Molina's statements, and 
they are better understood through Polanyi's conception of the double movement that posits that the state, despite ideology, has a role to play in mitigating the negative affects of the market upon the populace.

In a different vein from his past speeches, speaking at the World Economic Forum on Latin America in Panama on April $2^{\text {nd }}$ of 2014, Pérez Molina advocated that the best strategy for combating the drug problem was that of development, articulating an understanding that the problem is a product of the widespread poverty in the region. While President Pérez Molina's approach to development cannot be understood as disrupting the dominant neoliberal ideological paradigm, the fact that he understands the drug problem of being symptomatic of poverty is in line with counter-hegemonic statements issued by leaders like Evo Morales and publications by CELAC and UNASUR. Pérez Molina also understands Guatemala as an innocent bystander roped into the conflict by producer and consumer countries that are responsible. This is made clear when he says that the situation has been "forced on us" (2013). His calls for legalization are in direct tension with the dominant line of thought of both the United States and United Nations agencies. In this sense we can understand his statements as contributing to a broader counter-hegemonic position. This being said, Pérez Molina's strategy in dealing with the cartels closely mirrors the failed strategies of Mexican and Colombian administrations in conjunction with the US government. While on the one hand, as President, he prescribes the very strategies he critiques, on the other he goes further than any other sitting head of state in his calls for legalization, with the exception of José Mujica in Uruguay who has moved to legalize the production, sale and consumption of marijuana for Uruguayans. What becomes quite clear in the example of President Pérez 
Molina, is that the notion that the global prohibition regime is flawed and that current policies have failed, crosses ideological boundaries and conventional left-right distinctions. This suggests that the emerging counter-hegemonic discourse is gaining recruits on either end of the ideological spectrum.

\subsection{Conclusion}

While gains have been made in recent years in terms of reducing the level of violence, and increasing levels of prosecution, Guatemala continues to have one of the highest murder rates in the world and the police and military forces are still no match for the cartels and gangs in many parts of the country. Because of Guatemala's experience with the drug cartels, it is perhaps unsurprising that President Pérez Molina would make calls for change. What is surprising, however, is that the ideologically conservative, former military general would make very public calls for change that are in direct contention with the articulated positions of the United States and the United Nations in forums like the General Assembly. We can take President Pérez Molina's statements, in the context of the emergence of widespread critiques of orthodox policies, as evidence of a strong counter-hegemonic discourse surrounding drug policy that transcends ideological positions. The fact that this line of thought is being adopted by those who identify as ideologically right wing and would traditionally advocate for prohibition, further discredits the hegemonic ideas surrounding how to manage the problem of illicit drugs. In early April of 2014, speaking to reporters at the World Economic Forum on Latin American in Panama, Pérez Molina shared plans for policy innovations to be implemented in the near future that involve the legalization of illegal poppy fields along 
the Northern Mexican border so that production can be regulated and diverted to medical purposes (Reuters, 2014), indicating that the Guatemalan president intends to act upon his statements. The implementation of new strategies in Guatemala, by a conservative government, has the potential to further disrupt dominant ideas surrounding how the drug problem should be managed. While Cox and Robinson understand international institutions as propagators of international norms and absorbers of counter-hegemonic ideas, it will be interesting to whether the handful of Latin American leaders coming forth issuing similar statements to those of Otto Pérez Molina, will work to shift the trajectory of global drug policy in the upcoming U.N. Special Session on Narcotic substances in 2016 


\section{Chapter: Conclusion}

In recent years it has become quite evident that, 40 years after the inception of the War on drugs and 2.5 trillion US dollars later, there is little hope of achieving a drug free world through the means prescribed by the global prohibition regime as led and articulated most strongly by the United States. Drug production and consumption continue to sit at levels that they did prior to the onset of the most militaristic phase of the War on Drugs, and violence associated with illegal drug markets has spiraled beyond the control of governments in Mexico and Guatemala in recent years. Increasingly, we are seeing the recognition that the War on Drugs has quite simply been a failure. While the War on Drugs has wrought considerable turmoil in the Latin American region, we have seen shifts in policy at the level of nation states and a shift in discourse at the international level that suggest more widespread policy changes are likely to come in the not so distant future. In Latin American countries most detrimentally affected by the War on Drugs effort, alarming levels of violence continue to grip communities with fear and impede the capacity for economic development. Accordingly, in a Polanyian sense, it is unsurprising that we are seeing the emergence of a countermovement to remedy the side affects associated with decades of polices that are increasingly being understood as flawed. The principles of the global prohibition regime and the orthodox discourse are being discredited, opening spaces for innovation in thinking related to the drug problem. This reconceptualization is contingent upon shifting attitudes in the United States towards both how to manage the drug problem and direct foreign intervention by the US in the affairs of other countries under Obama and the decline of US hegemony in the Latin American region. Further, the successes of innovative policy directions in places like 
Bolivia and Uruguay is lending credibility to the notion that the War on Drugs has been a failure and that there must be movement in a different direction.

This thesis has explored how the shift away from the orthodox War on Drugs discourse has occurred, arguing that we are seeing the emergence of a strong counterhegemonic discourse surrounding drug production and consumption by both hegemonic and non hegemonic actors, and that the adoption of this new emerging discourse transcends ideological positions. This has been demonstrated by analyzing the reports of the Global Commission on Drugs and the OAS, as well as by examining the statements of prominent figures in international politics (or, members of the transnational elite), like Bill Clinton, Kofi Annan and Vicente Fox. This argument was furthered in examining the positions of UNASUR and CELAC to demonstrate that actors we can consider both hegemonic and disruptive of hegemony are increasingly finding common ground on this issue. The adoption of these new ideas across ideological positions in the Latin American context was further exemplified by exploring the recent Bolivian and Guatemalan experiences with the drug problem. The fact that the current administrations in Bolivia and Guatemala, who self-identify as standing at opposite ends of the ideological spectrum, have both spoken out in opposition of the principles of the global prohibition regime, is testament to the notion that this idea is coming to pervade ideological lines. The capacity of peripheral governments, like those in Guatemala and Bolivia, to influence the construction and propagation of international norms in such a significant way as they have been able to, is a reflection of a shifting balance of power in international institutions and the waning influence of the United States in Central and South America. Given that for Latin American governments distancing oneself from the 
United States is both politically popular and actually possible, given the decline of US hegemony in the region, new spaces have opened for initiating counter-hegemonic policy innovation. These developments can best be explained through neo-Gramscian lens that conceptualizes hegemony as ideational, consensual and diffused through an interlinked, global economy and counter-hegemony as being disruptive of the status-quo and transcending economic considerations. Liberal conceptions of international norm diffusion, despite their limitations, are further helpful in understanding the mechanical process by which norms come to be internationalized and taken for granted. Finally, Polanyi's notion of the 'double movement,' can help us to understand why it is that these ideas are coming to transcend ideological position, as those on both the left and the right have made calls for drug policy reform.

As Kofi Annan has articulated on several occasions, the shift in discourse around drug policy has not been met with widespread substantive policy changes. For the most part, the War on Drugs continues to be waged uninterrupted, much the same way it has over the course of the last forty years. Repressive tactics are still employed to eradicate coca at the source in the Andean region, while governments continue to battle the cartels. While it was far beyond the scope of this project to explore every example of policy ingenuity related to illicit drugs, as more and more places move towards reform and implement policies that run counter to the dominant line of thought over the course of the last forty years, the global prohibition regime and its associated approach to drug management is likely to be increasingly discredited. The implementations of harm reduction programs in the Scandinavian countries and in Canada have been successful in reducing the transmission of blood borne diseases amongst injecting drug users. Further, 
although such policies have only been implemented very recently, new experiments with marijuana legalization in Washington State, Colorado and in Uruguay are likely to inspire policy innovation in other jurisdictions. Policy experimentation in Bolivia under 'control social' has worked to strengthen the authority of the emerging counter-hegemonic discourse as members of the international community increasingly issue their support for the initiative. Finally, countries all over the world have moved towards the decriminalization of possession and consumption of small quantities of marijuana, suggesting that further change is likely to come. It is also clear that further policy innovation is on the horizon - President Otto Pérez Molina in Guatemala for example, has recently made mention of his government's intention to bring illegal poppy plantations along the Northern Guatemalan border under regulation. The issue is one that is contemporary in nature, and is evolving day by day - with each passing week we see developments that suggest we are moving away from the repressive tactics of the War on Drugs and towards a new hegemony concerning drug production and drug use.

Interestingly, the upcoming UN General Assembly Special Session on Drugs was originally scheduled for 2019. However, upon the request of the governments of Mexico, Colombia and Guatemala, a motion was put forth in the General Assembly to move the session forward (IDCP, 2012). The motion received widespread support and was cosponsored by 95 members of the General Assembly. Accordingly, the Special Session has been rescheduled for 2016. The passing of this motion is significant, in that it implies that members of the General Assembly understand the issue as one that needs to be managed with haste. Further, the passing of the motion is indicative of shifting attitudes towards the global drug prohibition regime, as the purpose of such a conference is to revisit the 
UN legislation surrounding drug management and debate alternate strategies. If we can understand institutions like the $\mathrm{UN}$ as agents of ideational hegemony, we have an indication that ideas surrounding drug production and consumption are likely to shift even further, and that substantive policy change is likely to follow. 


\section{Bibliography}

1961 Single Convention on Narcotic Drugs (United Nations).

2013 INCSR: Country Reports - Croatia through Haiti. (2013, March 05). Retrieved from http://www.state.gov/j/inl/rls/nrcrpt/2013/vol1/204049.htm

Adams, G. (2011, November 5). Guatemala's bloody battle with Mexican drug cartels. Retrieved from http\%3A\%2F\%2Fwww.independent.co.uk\%2Fnews\%2Fworld\%2Famericas\%2F guatemalas-bloody-battle-with-mexican-drug-cartels-6257571.html

Al Jazeera. (2013, July 25). Report says 220,000 died in Colombia conflict. Retrieved from http://www.aljazeera.com/news/americas/2013/07/201372511122146399.html

Alford-Jones, K. (2013, January 25). Remilitarization Gives Rise to New Tensions and Violence in Guatemala. Retrieved from http://upsidedownworld.org/main/guatemala-archives-33/4095-remilitarizationgives-rise-to-new-tensions-and-violence-in-guatemala

Álvarez Velasco, C. (2013). El consejo Suramericano sobre el problema mundial de las drogas de le UNASUR logros y desafios 2012-2013 (Rep.). International Drug Policy Consortium.

Annan, K., \& Cardoso, F. H. (2013, November 05). Kofi Annan: Stop 'war on drugs' Retrieved January 12J, 2014, from http://www.cnn.com/2013/11/05/opinion/annan-cordoso-humane-drug-policy/

Anuncian creación de observatorios nacionales de drogas y evaluación de temas relacionados con narcotráfico (Rep.). (2011). La Paz: UNASUR.

BBC. (2007, November 11). Ex-general wins Guatemala run-off. Retrieved from http://www.bbc.com/news/world-latin-america-15594159

BBC (2008, September 11). Washington expels Bolivian envoy. Retrieved from http://news.bbc.co.uk/2/hi/americas/7610915.stm

Bewley-Taylor, D. (2002). Habits of a hegemon. Transnational Institute. 
Bolivia, Consejo Nacional de Lucha Contra el Tráfico Ilícito de Drogas. (2007).

Estrategia de lucha contra el narcotráfico y revalorización de la hoja de coca 2007-2010. La Paz.

Bolivia, Consejo Nacional de Lucha Contra el Tráfico Ilícito de Drogas. (2011). Estrategia de lucha contra el narcotráfico y reducción de cultivos excentarios de coca 2011-2015. La Paz.

Bolivia leader can seek third term. (2013, April 30). Retrieved March, 2014, from http://www.bbc.com/news/world-latin-america-22351190

Booth, W. (2012, December 01). Mexico's crime wave has left about 25,000 missing, government documents show. Retrieved March 5, 2014, from http://www.washingtonpost.com/world/the_americas/mexicos-crime-wave-hasleft-up-to-25000-missing-government-documents-show/2012/11/29/7ca4ee443a6a-11e2-9258-ac7c78d5c680_story.html

Brands, H. (2010). Crime, violence and the crisis in Guatemala: A case study in the erosion of the state (Rep.). Carlisle: Strategic Studies Institute.

Carpenter, T. G. (2003). Bad neighbour policy: Washington's futile war on drugs in Latin America. New York: Palgrave Macmillan.

CDC. (2014, February 10). Drug overdose in the United States: Fact sheet. Retrieved January 22, 2014, from http://www.cdc.gov/homeandrecreationalsafety/overdose/facts.html

CEPALSTAT. (2013) National economic profile: Plurinational State of Bolivia. Retrieved March 24, 2014, from http://interwp.cepal.org/cepalstat/WEB cepalstat/Perfil_nacional_economico.asp? Pais $=$ BOL\&idioma $=\mathrm{i}$

Chalabi, M., \& Burn-Murdoch, J. (2012, November 30). Where are world's deadliest major cities? Retrieved from http://www.theguardian.com/news/datablog/2012/nov/30/new-york-crime-freeday-deadliest-cities-worldwide

CIA. (2014). The world factbook: Guatemala. Retrieved from https://www.cia.gov/library/publications/the-world-factbook/geos/gt.html

CIDOB. (2013, March 5). Otto Pérez Molina. Retrieved from http://www.cidob.org/en/documentacio/biografias_lideres_politicos/america_cent ral_y_caribe/guatemala/otto_perez_molina

Comunicado especial sobre el problema mundial de las drogas (Rep.). (2011). CELAC. 
Comunicado especial sobre la coca originaria y ancestral, patrimonia natural de Bolivia y Perú (Rep.). (2013). CELAC.

Cox, R. W. (1983). Gramsci, Hegemony and International Relations : An Essay in Method. Millennium - Journal of International Studies, 12(2), 162-175.

Cox, R. W. (1987). Production, power, and world order: Social forces in the making of history. New York: Columbia University Press.

Crick, E. (2012). Drugs as an existential threat: An analysis of the international securitization of drugs. International Journal of Drug Policy, 23(5), 407-414.

Davos 2014 - The Drugs Dilemma: Consequences for Society, Politics and Business. (2014, January 31). Retrieved February 15, 2014, from https://www.youtube.com/watch? $\mathrm{v}=\mathrm{G} 4 \mathrm{hT} 2 \mathrm{CJ}$ w2 28

DEA / Foreign Office Locations. (2014). Retrieved from http://www.justice.gov/dea/about/foreignoffices.shtml

DEA Leadership. (2014.). Retrieved from http://www.justice.gov/dea/about/leadership.shtml

Deibert, M. (2009). Guatemala's Death Rattle: Drugs vs. Democracy. World Policy Journal, 25(4), 167-175.

Dijk, T. A. (1993). Principles of Critical Discourse Analysis. Discourse \& Society, 4(2), 249-283.

The drug problem in the Americas (Rep). (2013). Washington: The Organization of American States.

The drug war, mass incarceration and race. (2014). Retrieved from http://www.drugpolicy.org/sites/default/files/DPA_Fact_Sheet_Drug_War_Mass_ Incarceration_and_Race_Feb2014.pdf

Embassy of the United States to Guatemala. (2012, February 12). US embassy statement on decriminalizing drugs. Retrieved from http://guatemala.usembassy.gov/pbe07_20120212.html

European Union, European Parliament. (2007). Green paper on the role of civil society in drugs policy in the European Union. Strasbourg.

Farthing, L., \& Kohl, B. (2001). The price of success: Bolivia's war against drugs and the poor. NACLA Report on the Americas, 35(1), 35-51. 
Farthing, L., \& Kohl, B. (2010). Social Control: Bolivia's New Approach to Coca Reduction. Latin American Perspectives, 37(4), 197-213.

Fielding Mellen, C., \& Grostein Andrade, F. (Directors). (2011). Breaking the Taboo [Motion picture]. Sundog Pictures.

Finnemore, M., \& Sikkink, K. (1998). International Norm Dynamics and Political Change. International Organization, 52(4), 887-917.

Forero, J. (2013, January 1). Brazil's Drug Epidemic: Welcome To 'Crackland' Retrieved March 3, 2014, from http://www.npr.org/2013/01/01/168072712/brazils-drugepidemic-welcome-to-crackland

Fox, V. (2014, February 17). For Mexico, legalization is freedom. The Globe and Mail.

Freeman, L. (2006). State of siege: Drug related violence and corruption in Mexico (Rep.). Washington: Washington Office on Latin America.

Friedersdorf, C. (2014, January 21). Obama on Pot Legalization: 'It's Important for It to Go Forward' Retrieved February 4, 2014, from http://www.theatlantic.com/politics/archive/2014/01/obama-on-pot-legalizationits-important-for-it-to-go-forward/283201/

George H.W. Bush speech on drugs. (2011, September 08). Retrieved from https://www.youtube.com/watch?v=heTB8gcwwuk

George W. Bush: Fact Sheet: Andean Regional Initiative. (2001). Retrieved from http://www.presidency.ucsb.edu/ws/?pid=78819\#axzz2j1sI4JTa

Gill, L. (2004). The School of the Americas: Military training and political violence in the Americas. Durham: Duke University Press.

Gills, B. K. (2000). Introduction: Globalization and the politics of resistance. In Globalization and the politics of resistance. New York, NY: St. Martin's Press.

Global illicit drug trends 2000 (Rep.). (2000). New York: United Nations Office on Drugs and Organized Crime.

Goldacre, B. (2009, June 13). Cocaine study that got up the nose of the US. Retrieved from http://www.theguardian.com/commentisfree/2009/jun/13/bad-sciencecocaine-study

Grandin, G. (2006). Empire's workshop: Latin America, the United States, and the rise of the new imperialism. New York: Metropolitan Books. 
Grisaffi, T. (2010). We Are Originarios ...'We Just Aren't from Here': Coca leaf and Identity Politics in the Chapare, Bolivia. Bulletin of Latin American Research, 29(4), 425-439.

Guatemala. (2013). 68th session of the United Nations General Assembly: The post 2015 development agenda, statement by H.R. Mr Otto Fernando Pérez Molina. La Ciudad de Guatemala: Gobierno de Guatemala.

Harvey, D. (2005). A brief history of neoliberalism. Oxford: Oxford University Press.

Hawdon, J. E. (2001). The role of presidential rhetoric in the creation of a moral panic: Reagan, bush, and the war on drugs. Deviant Behavior, 22(5), 419-445.

Holt, E. (2010). Russian injected drug use soars in face of political inertia. The Lancet, 376(9734), 13-14.

Human Rights Watch. (2013). World Report 2013: Guatemala. Retrieved from http://www.hrw.org/world-report/2013/country-chapters/guatemala?page=2

Human Rights Watch. (1995). Bolivia: Human rights violations and the war on drugs. Human Rights Watch/Americas, 7(8).

Immigration and Refugee Board of Canada. (2006, October 26). Guatemala: Treatment of gay, lesbian, bisexual and transgendered/transsexual individuals and availability of state protection; police attitudes towards same-sex domestic violence and state protection available to victims (2003 - September 2006). Retrieved from http://www.refworld.org/docid/45f1473e11.html

Isacson, A. (2012, May 22). Conflict Resolution in the Americas: The Decline of the OAS. Retrieved April 7, 2014, from http://www.worldpoliticsreview.com/articles/11979/conflict-resolution-in-theamericas-the-decline-of-the-oas

Keefe, P. R. (2012, June 16). Cocaine Incorporated. Retrieved from http://www.nytimes.com/2012/06/17/magazine/how-a-mexican-drug-cartelmakes-its-billions.html?pagewanted $=1$

Kohl, B., \& Bresnahan, R. (2010). Bolivia under Morales: Consolidating Power, Initiating Decolonization. Latin American Perspectives, 37(3), 5-17.

Kohl, B. H., \& Farthing, L. C. (2006). Impasse in Bolivia: Neoliberal hegemony and popular resistance. London: Zed Books.

Lacey, M. (2007, August 03). Drug Gangs Use Violence to Sway Guatemala Vote. Retrieved from http://www.nytimes.com/2007/08/04/world/americas/04guatemala.html?pagewant $\mathrm{ed}=\mathrm{all} \& \_\mathrm{r}=0$ 
Léons, M. B., \& Sanabria, H. (1997). Coca, cocaine, and the Bolivian reality. Albany: State University of New York Press.

Machin, D., \& Mayr, A. (2012). How to do critical discourse analysis: A multimodal introduction. Los Angeles: SAGE.

McAllister, W. B. (2000). Drug diplomacy in the twentieth century: An international history. London: Routledge.

Meiners, S. (2009). Central America: An emerging role in the drug trade. Security Weekly. Retrieved from http://www.stratfor.com/weekly/20090326_central_america_emerging_role_drug trade

Mill, J. S. (2006). On liberty. London: Penguin.

Mittleman, J., \& Chin, C. (2000). Conceptualizing resistance to globalism. In Globalization and the politics of resistance. New York, NY: St. Martin's Press.

Morales's MAS Government: Building Indigenous Popular Hegemony in Bolivia. (2010). Latin American Perspectives, 37(3), 18-34.

Morton, A. (2000). Mexico, neoliberal restructuring and the EZLN: A neo-Gramscian analysis. In Globalization and the politics of resistance. New York: St. Martin's Press.

Mulholland, J. (2013, January 20). Guatemala's president: 'My country bears the scars from the war on drugs' Retrieved from http://www.theguardian.com/world/2013/jan/19/otto-molina-war-drugs-guatemala

Murkin, G., Kushlick, D., Powell, M., Rolles, S., \& Slater, J. (2012). The alternative world drug report: Counting the costs of the war on drugs (Rep.). London: Count the Costs.

Nadelmann, E. A. (1990). Global prohibition regimes: The evolution of norms in international society. International Organization, 44(04), 479.

National Security Decision Directive 221 (United States Government 1986).

Objections and support for Bolivia's coca amendment - Drug Law Reform in Latin America. Retrieved January 24, 2014, from http://www.druglawreform.info/en/issues/unscheduling-the-coca-leaf/item/1184objections-and-support-for-bolivias-coca-amendment

Observatorio Suramericano de Drogas y crimen transnacioal seràn analizados por UNASUR (Rep.). (2012). Acunción: UNASUR. 
O'Meara, D. (2010). Hegemony, militarism and identity: Locating the United States as the global power. In W. S. Cox \& B. Charbonneau (Eds.), Locating global order: American power and Canadian security after 9/11. Vancouver: UBC Press.

OSAC. (2013, December 4). Guatemala 2013 Crime and Safety Report. Retrieved from https://www.osac.gov/pages/ContentReportDetails.aspx?cid=13878

Paltridge, B. (2006). Discourse analysis: An introduction. London: Continuum.

Park, S. (2006). Theorizing Norm Diffusion Within International Organizations. International Politics, 43(3), 342-361.

Paz, J. F. (2008, August 05). Bolivia's Surprising Anti-Drug Success. Retrieved April 1, 2014, from http://content.time.com/time/world/article/0\%2C8599\%2C1829782\%2C00.html

Polanyi, K. (1957). The great transformation. Boston: Beacon Press.

Raymond Yans al WeFree Days 2013. (2013, October 12). Retrieved April 1, 2014, from https://www.youtube.com/watch?v=QPPaCn3btAk

Reinarman, C. (1994). The Social Construction of Drug Scares. In P. A. Adler \& P. Adler (Eds.), Constructions of deviance: Social power, context, and interaction. Belmont, CA: Wadsworth Pub.

Remnick, D. (2014, January 27). On and off the road with Barack Obama. Retrieved March 24, 2014, from http://www.newyorker.com/reporting/2014/01/27/140127fa_fact_remnick?current Page $=$ all

Report of the global commission on drug policy (Rep.). (2011). Global Commission on Drug Policy.

Resignato, A. J. (2000). Violent crime: A function of drug use or drug enforcement? Applied Economics, 32(6), 681-688.

Richard Nixon: Remarks During a Visit to New York City To Review Drug Abuse Law Enforcement Activities. (n.d.). Retrieved from http://www.presidency.ucsb.edu/ws/?pid=3779

Robinson, W. I. (1996). Promoting polyarchy: Globalization, US intervention, and hegemony. Cambridge: Cambridge University Press. 
Robinson, W. I. (2005). Gramsci and Globalisation: From Nation- State to Transnational Hegemony. Critical Review of International Social and Political Philosophy, $8(4), 559-574$.

Robinson, W. I. (2012). Latin America in the new global capitalism. NACLA Report on the Americas, 45(2), 13-18.

Romero, S. (2008, September 10). Bolivia Orders U.S. Ambassador to Leave, Accusing Him of Supporting Rebel Groups. Retrieved April 01, 2013, from http://www.nytimes.com/2008/09/11/world/americas/11bolivia.html?_r=2\&

Ronald Reagan: Remarks in New Orleans, Louisiana, at the Annual Meeting of the International Association of Chiefs of Police. (n.d.). Retrieved from http://www.presidency.ucsb.edu/ws/?pid=44300

Russell, R., \& Tokatlian, J. G. (2011). Beyond Orthodoxy: Asserting Latin America's New Strategic Options Toward the United States. Latin American Politics and Society, 53(4), 127-146.

Savage, C. (2011, November 06). D.E.A. Squads Extend Reach of Drug War. Retrieved from http://www.nytimes.com/2011/11/07/world/americas/united-states-drugenforcement-agency-squads-extend-reach-of-drugwar.html?pagewanted=all\&_r=0\&gwh=90A84FAF843425B2767B7287B90E69F $7 \& g w t=$ regi

Shoichet, C. E., Lopez, J. C., Washington, J. D., Janiot, P., \& Atlanta, M. E. (1970, January 01). Guatemalan president leads drug legalization debate. Retrieved from http://www.cnn.com/2012/03/23/world/americas/guatemala-drug-legalization/

Shultz, J., \& Draper, M. (2008). Dignity and defiance: Stories from Bolivia's challenge to globalization. Berkeley: University of California Press.

Single convention on narcotic drugs, 1961, as amended by the protocol amending the single convention on narcotic drugs, 1961. (n.d.). Retrieved February 24, 2014, from

https://treaties.un.org/pages/ViewDetails.aspx?src=TREATY\&mtdsg_no=VI$18 \&$ chapter $=6 \&$ lang $=$ en\#EndDec

Stevenson, M. (2011, January 12). Mexico: 34,612 Drug War Deaths; 15,273 In 2010. Retrieved January 24, 2014, from http://www.huffingtonpost.com/2011/01/12/mexico-drug-war-deaths2010_n_808277.html

Stolberg, V. (2011). The Use of Coca: Prehistory, History, and Ethnography. Journal of Ethnicity in Substance Abuse, 10(2), 126-146. 
Storm Miller, A. (2010). A sword cuts two ways: Cold War policy making in the OAS. Llilas Annual Review. Retrieved from http://anic.utexas.edu/project/etext/lilas/portal/portal109/oas.pdf

Thematic debate of the 66th session of the UN General Assembly on drugs and crime as a threat to development. (2012, June 26). Retrieved March 14, 2014, from http://www.un.org/en/ga/president/66/Issues/drugs/drugs-crime.shtml

Thompson, C. (2013, May 8). Is Obama delivering on his promise of a "21st Century" approach to drugs? Retrieved October 24, 2013, from http://www.propublica.org/article/is-obama-delivering-on-his-promise-of-21stcentury-approach-to-drugs

Torrents, C., \& Ruiz-Goreirina, R. (2012, September 25). Guatemala Drug Legalization: Otto Perez Molina, Guatemala President, Says Legalize Drugs. Retrieved from http://www.huffingtonpost.com/2012/09/25/guatemala-druglegalization_n_1914042.html

Tran, R. (2011). Guatemala: A stalled peace. Washington Report on the Hempisphere, $31(8)$.

Tussie, D. (2012). The rise of post hegemonic regionalism in Latin America. In P. Riggirozzi (Author), The rise of post-hegemonic regionalism: The case of Latin America. Dordrecht: Springer.

UN convention against illicit traffic in narcotic drugs (United Nations 1988).

UNifeed. (2011, July 27). UN/Evo Morales. Retrieved from http://www.unmultimedia.org/tv/unifeed/2011/07/un-evo-morales-3/

UNODC. (2012, September 17). Coca crop cultivation "falls significantly" in Bolivia, according to 2011 coca monitoring survey. Retrieved from http://www.unodc.org/unodc/en/frontpage/2012/September/coca-crop-cultivationfalls-significantly-in-bolivia-according-to-2011-coca-monitoring-survey.html

UNODC. (2013). UNODC homicide statistics 2013. Retrieved from https\%3A\%2F\%2Fwww.unodc.org\%2Fgsh\%2Fen\%2Fdata.html

US Department of Defence. (1994). Cable 43-02. Retrieved from http://www2.gwu.edu/ nsarchiv/NSAEBB/NSAEBB32/43-02.htm

US State Department. ( 2008, September 11). State Department Statement on Expulsion of Ambassador Goldberg from Bolivia. 
USAID. (2009, November 20). United States and Guatemala Sign Merida Initiative Agreement. Retrieved from http://www.usaid.gov/content/united-states-andguatemala-sign-merida-initiative-agreement

WEF. (2014, April 02). Panama 2014 - Opening Plenary: Opening Pathways for Shared Progress. Retrieved from https://www.youtube.com/watch?v=FyzX5XxzBlc\&list=PL7m903CwFUgmDpz1 8gqqshSzEMf3qvjPb

Werb, D., Kerr, T., Nosyk, B., Strathdee, S., Montaner, J., \& Wood, E. (2013). The temporal relationship between drug supply indicators: An audit of international government surveillance systems. BMJ Open, 3(9), E003077-E003077.

Wodak, R., \& Meyer, M. (2001). Methods of critical discourse analysis. London: SAGE. Wood, E. (2011, June 07). Organized crime won the war on drugs. Retrieved from http://www.cnn.com/2011/OPINION/06/07/wood.failed.war.on.drugs/

The White House. (2008, October 16). Press Release: President Bush Signs H.R. 7222, the Andean Trade Preference Act Extension.

The World Bank. (2014). Data: Guatemala. Retrieved from http://data.worldbank.org/country/guatemala

World drug report 2013 (Rep.). (2013). New York: United Nations Office on Drugs and Organized Crime.

Worth, O., \& Kuhling, C. (2004). Counter-hegemony, anti-globalisation and culture in International Political Economy. Capital \& Class, 28(3), 31-42. 